\title{
A influência da ferramenta "computador" no processo de desenvolvimento de uma marca: o caso da Caixa Econômica Federal
}

\section{Paulo Henrique Frediani de Moura}

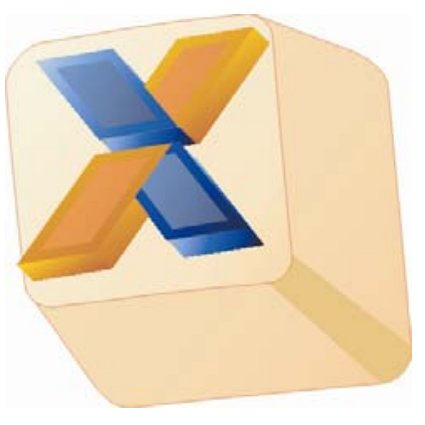

Dissertação apresentada à Faculdade de Arquitetura e Urbanismo, da Universidade de São Paulo, como parte dos requisitos para obtenção do título de Mestre em Design \& Arquitetura.

Prof. Dr. Alessandro Ventura (Orientador)

São Paulo

2006 
Ficha Catalográfica|

AUTORIZO A REPRODUÇÃO E DIVULGAÇÃO TOTAL OU PARCIAL DESTE TRABALHO, POR QUALQUER MEIO CONVENCIONAL OU ELETRÔNICO, PARA FINS DE ESTUDO E PESQUISA, DESDE QUE CITADA A FONTE.

Faculdade de Arquitetura e Urbanismo da Universidade de São Paulo

MOURA, Paulo Henrique Frediani de.

A influência da ferramenta "computador" no processo de desenvolvimento de uma marca - o caso da Caixa Econômica Federal/Paulo Henrique Frediani de Moura; Orientador Alessandro Ventura - São Paulo, 2006.

Dissertação (Mestrado - Programa de Pós-Graduação em Arquitetura e Urbanismo/Área de Concentração: Design e Arquitetura) - Faculdade de Arquitetura e Urbanismo, Universidade de São Paulo. 
Folha de Aprovação

Paulo Henrique Frediani de Moura

A influência da ferramenta "computador" no processo de desenvolvimento de uma marca - o caso da Caixa Econômica Federal

Dissertação apresentada à Faculdade de Arquitetura e Urbanismo, da Universidade de São Paulo, como parte dos requisitos para obtenção do título de Mestre.

Área de Concentração: Design \& Arquitetura.

Aprovado em

Banca Examinadora

Prof. Dr. Alessandro Ventura (Orientador)

FAU/USP Assinatura

Prof. Dr. Heliodoro Teixeira Bastos

ECA/USP Assinatura

Prof. Dr. Carlos Alberto Inacio Alexandre

FAU/USP Assinatura 


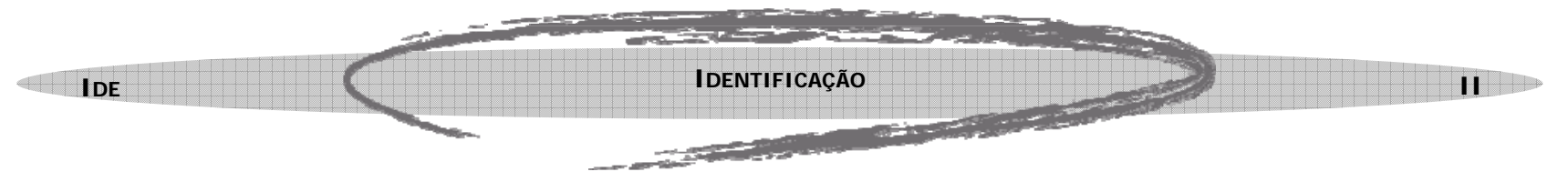

Dedicatória

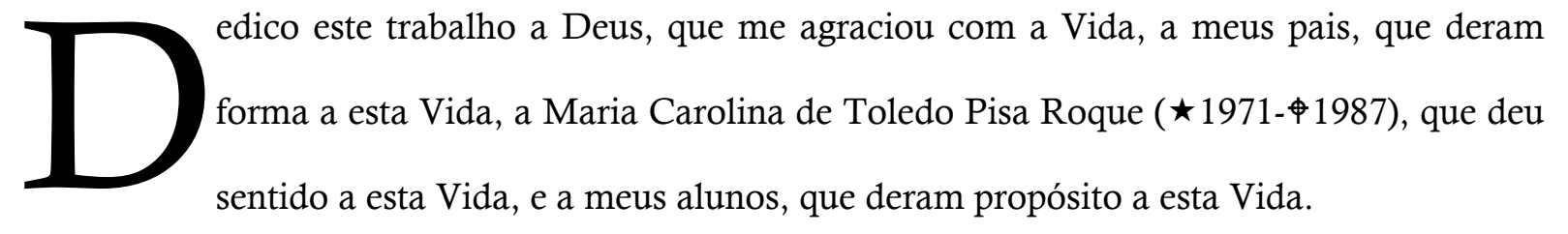

Agroto dum anima est, spes est.

(Enquanto há vida, há esperança.) 


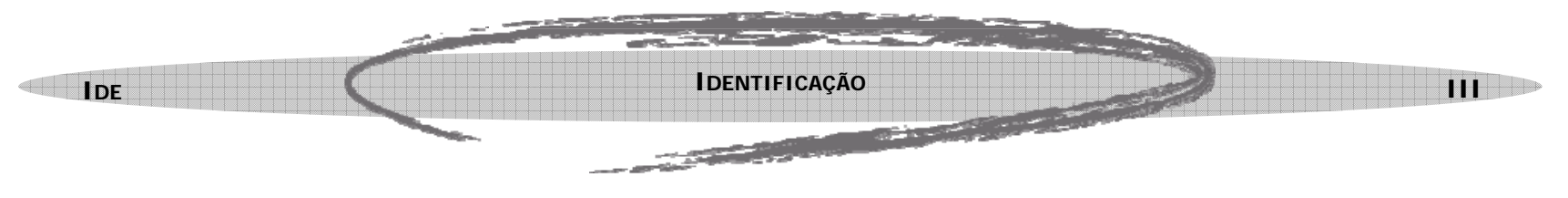

Agradecimento

ada se faz sem o apoio e a ajuda de nossos entes queridos. Desta maneira, cabe
aqui registrar o justo reconhecimento a todos que, de algum modo, tornaram esta
dissertação possível:

A meu orientador, Prof. Dr. Alessandro Ventura, pela confiança, orientação e amizade.

Ao "Trio de Ouro": Alexandre de Paula Mora, Claudir Segura e Leônidas Hildebrand Jr, cujo apoio, amizade, incentivo e cobrança deram forma a esta dissertação, apreço que não pode ser colocado em meras palavras.

Aos colegas de orientação, Jane, Caio, Fábio, Ferreti, Franklin, Gustavo e Wilhelm, cujas discussões, às vezes acirradas, abriram caminhos que nunca pensaria em trilhar sozinho.

Aos colegas das Faculdades Oswaldo Cruz (Ana Cláudia, Eleida, João Carlos, Machado, Mário Sérgio, Negrão, Oliveira, Rodger, Rubens, Samuel, Sparapan, Tony, Vitor e tantos outros), da Caixa Econômica Federal (Ana Cristina, Ana Luiza, Joana, Lu Royer, Lu Versiani, Magda, Marília, Sandra, Sílvia, Six, Sobeh, Celso, Christiano, Gustavo, Moizés, Silmar, Sílvio, Wilson, Xexéu, Zig e dezenas mais) e do curso de Pós-Graduação da FAU-USP (Carla, Emilene, Mariana, Núria, Stella, Thais, Virgínia, Vivian, Viviane, Benê, Bortoloto, Cury, Kleber, Marcos, Paulov, Takao, Zanolla e muitos mais), meu agradecimento pelas pizzas e caipirinhas, mantendo meu foco em um único problema...

Aos professores e funcionários da FAU-USP, pelo carinho e atenção constantes. 
Às fiéis amigas Cathé, Fabsie, Mi, Márcia VP, Sashibell e Sizinha, em tempos diferentes, de modos diferentes, meu coração é de vocês: dividam entre si, que ele é grande, por culpa de vocês mesmas!

À minha família (pais, irmãos, avôs, tios e primos), a base de tudo que se faz bem feito.

Por fim, agradeço também a você, que contribuiu direta ou indiretamente para a elaboração deste trabalho, mas cujo nome não foi citado expressamente aqui, por culpa de um alemão que muito me acompanhou no desenvolvimento desta dissertação: "herr Stress"! 


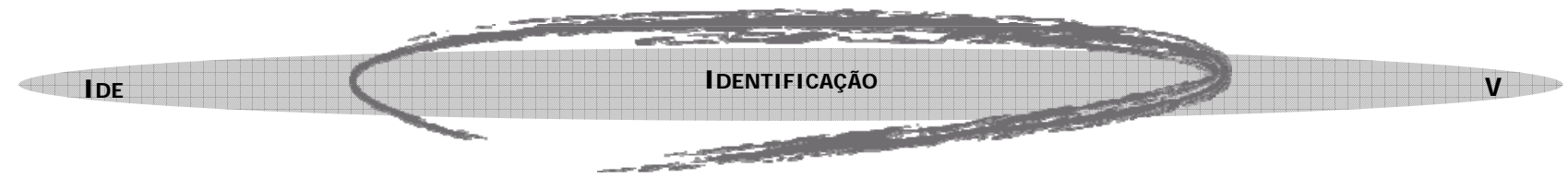

Epígrafe

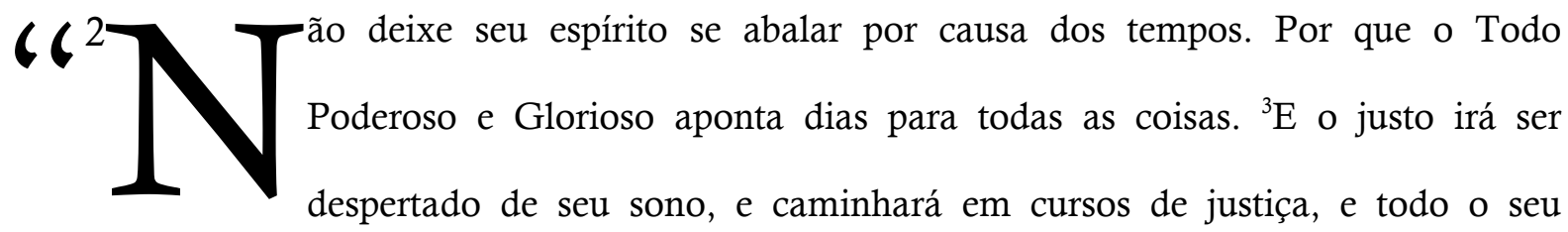
caminho e conversão serão realizados na bondade e na graça eternas."

\section{Livro de Enoque XCII, 2-3}


MOURA, Paulo Henrique Frediani de. A influência da ferramenta "computador" no processo de desenvolvimento de uma marca - o caso da Caixa Econômica Federal. São Paulo, 2006. Dissertação (Mestrado) - Faculdade de Arquitetura e Urbanismo, Universidade de São Paulo.

A presente dissertação aborda a interferência do uso da tecnologia da computação gráfica na criação e no gerenciamento de marcas corporativas. O estudo começa com uma discussão sobre a terminologia utilizada na área, seguido por um manifesto sobre a importância do Design e o relato histórico da evolução do computador. A análise termina com o estudo do caso da Caixa Econômica Federal, que teve a sua marca remodelada algumas vezes em quase 150 anos de existência, com diversas formas e níveis de influência do computador neste processo. O resultado é permeado de recomendações para se usar o computador como uma poderosa ferramenta e se atingir a melhor solução ao trabalho de Design.

Palavras-chave: Marca, Logotipo, Computador, Design, Caixa Econômica Federal. 


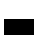

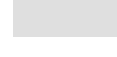

MOURA, Paulo Henrique Frediani de. The influence of the computer as a tool in the process of brand development - the case of Caixa Econômica Federal. São Paulo, 2006. Dissertation (Master of Science Degree) - Faculdade de Arquitetura e Urbanismo, Universidade de São Paulo.

This dissertation covers the influence of the computer graphics technology use in the corporate brand creation and development. The study begins by reasoning over the nomenclature in this specific field, followed by a design heightening manifest and the historical report on computer evolution. The analysis finishes with the Caixa Econômica Federal case, which brand was redesigned few times over almost 150 years of existence, in different ways and levels of computer influence in this process. The outcome is enriched by recommendations in how to use the computer as a powerful tool and how to achieve the best solution in the design work.

Keywords: Brand, Logotype, Computer, Design, Caixa Econômica Federal. 
Lista de Ilustrações

\begin{tabular}{|c|c|c|}
\hline Fig. & Título & Pág. \\
\hline 01 & Gôndola de supermercado & 18 \\
\hline 02 & Avenida Angélica, São Paulo & 18 \\
\hline 03 & A pegada inicial & 21 \\
\hline 04 & Logotipo do Estado de Vermont (não oficial) & 23 \\
\hline 05 & Representação gráfica do duplo hélice de DNA & 24 \\
\hline 06 & A briga pelo combustível & 24 \\
\hline 07 & Coca-Cola em Israel (versão Light) & 25 \\
\hline 08 & McDonalds no Reino do Bahrein & 25 \\
\hline 09 & Logotipo da Pepsi & 27 \\
\hline 10 & Símbolo Gráfico da Pepsi & 28 \\
\hline 11 & Logomarca da Pepsi & 29 \\
\hline 12 & A marca bem mantida vale ouro & 31 \\
\hline 13 & Logotipo da Marlboro & 32 \\
\hline 14 & Conquistando clientes & 34 \\
\hline 15 & Marketing Jurássico? & 34 \\
\hline 16 & Marketing na Bíblia? & 35 \\
\hline 17 & Desejo à francesa & 36 \\
\hline 18 & Sites racistas: tornam o computador em uma ferramenta demoníaca? & 39 \\
\hline 19 & Logotipos da Exxon e do Greenpeace: marcas são boas ou ruins pelo perfil das empresas? & 39 \\
\hline 20 & Interior de uma fábrica inglesa (séc. XVIII) & 40 \\
\hline 21 & A sátira de Charles Chaplin aos "Tempos Modernos" & 40 \\
\hline 22 & Edifício Sede da Staatliches Bauhaus, em Dessau, Alemanha & 40 \\
\hline 23 & Walter Gropius, primeiro diretor da Bauhaus & 40 \\
\hline 24 & Peças de xadrez, produzidas por alunos da Bauhaus & 40 \\
\hline 25 & Máquina de Voar, de da Vinci: Design tradicional? & 42 \\
\hline 26 & Adam Smith & 42 \\
\hline 27 & Logotipo da Coca-Cola & 44 \\
\hline 28 & A televisão e o lifestyle & 44 \\
\hline 29 & Jeep o acompanha a qualquer lugar & 45 \\
\hline 30 & Pássaro resgatado de desastre ecológico & 45 \\
\hline 31 & Logomarca do Forest Stewardship Council - FSC, única certificação ambiental aceita globalmente & 45 \\
\hline 32 & A editoração eletrônica & 47 \\
\hline
\end{tabular}




\begin{tabular}{|c|c|c|}
\hline 33 & Material tradicional de design gráfico & 47 \\
\hline 34 & A simplificação da informática e o perfil do "novo concorrente" do designer & 49 \\
\hline 35 & O computador e a preguiça & 51 \\
\hline 36 & Toda nova tecnologia tem início em outra precedente & 53 \\
\hline 37 & Logomarca da Metro-Goldwyn-Meyer & 56 \\
\hline 38 & Yin Yang: unificação e segregação & 56 \\
\hline 39 & VolksWagen: atemporal & 57 \\
\hline 40 & Ábaco & 60 \\
\hline 41 & Régua de cálculo & 60 \\
\hline 42 & Máquina Pascalina & 60 \\
\hline 43 & Aritmômetro & 60 \\
\hline 44 & Máquina Diferencial & 60 \\
\hline 45 & Computômetro & 61 \\
\hline 46 & Tabulador de Censo & 61 \\
\hline 47 & Marca original (1924) & 62 \\
\hline 48 & Logotipo atual (1972) & 62 \\
\hline 49 & A "escala humana" do Mark 1 & 62 \\
\hline 50 & Mark 1 & 62 \\
\hline 51 & Colossus 1 & 62 \\
\hline 52 & ENIAC & 63 \\
\hline 53 & Computador a válvula & 63 \\
\hline 54 & Univac modelo 1105 & 63 \\
\hline 55 & Primeiro transistor & 64 \\
\hline 56 & Transistor "moderno" & 64 \\
\hline 57 & IBM 7094 & 64 \\
\hline 58 & CDC 6600 & 64 \\
\hline 59 & Chip do IBM 360 & 64 \\
\hline 60 & Logotipo Intel & 65 \\
\hline 61 & Chip Intel 4004 & 65 \\
\hline 62 & Microprocessador & 65 \\
\hline 63 & MITS Altair 8800 & 65 \\
\hline 64 & Paul Allen (sentado) e Bill Gates & 66 \\
\hline 65 & Logotipo Xerox & 66 \\
\hline 66 & Xerox Alto & 66 \\
\hline 67 & Interface gráfica & 66 \\
\hline 68 & Apple I & 67 \\
\hline 69 & IBM PC & 67 \\
\hline 70 & Stephen Wozniak (esquerda) e Steve Jobs & 67 \\
\hline 71 & Símbolo Gráfico original da Apple & 67 \\
\hline 72 & Apple II & 67 \\
\hline
\end{tabular}




\begin{tabular}{|c|c|c|}
\hline 73 & Logotipo Radio Shack & 68 \\
\hline 74 & TRS-80 & 68 \\
\hline 75 & Logomarca Commodore & 68 \\
\hline 76 & PET 2001 & 68 \\
\hline 77 & Apple MacIntosh & 68 \\
\hline 78 & Apple IIc & 68 \\
\hline 79 & Commodore Amiga & 68 \\
\hline 80 & Logomarca Atari & 69 \\
\hline 81 & Atari 520ST & 69 \\
\hline 82 & IBM PC & 69 \\
\hline 83 & IBM PC-XT & 69 \\
\hline 84 & IBM PC-AT & 70 \\
\hline 85 & IBM PS/2 & 70 \\
\hline 86 & Símbolo Gráfico do Sistema Linux (distribuição brasileira: Kurumim) & 71 \\
\hline 87 & Tela do CorelDraw & 71 \\
\hline 88 & Tela do 3DMax & 72 \\
\hline 89 & A "relação" software-hardware & 73 \\
\hline 90 & Logomarca original da Caixa Econômica Federal & 75 \\
\hline 91 & Dom Pedro II & 75 \\
\hline 92 & Princesa Isabel & 76 \\
\hline 93 & Logomarca das Loterias da Caixa & 76 \\
\hline 94 & Logomarca do Banco Nacional de Habitação & 76 \\
\hline 95 & Logomarca do Fundo de Garantia por Tempo de Serviço & 77 \\
\hline 96 & Logotipo atual da Caixa Econômica Federal & 77 \\
\hline 97 & Melhorando a vida dos brasileiros & 77 \\
\hline 98 & O Código de Ética garante a tranqüilidade do cliente da Caixa & 78 \\
\hline 99 & Logotipo da Caixa Cultural & 79 \\
\hline 100 & Detalhe de vitral em conjunto cultural da Caixa (Edifício Sé, São Paulo) & 79 \\
\hline 101 & Conjunto cultural da Caixa, em São Paulo & 80 \\
\hline 102 & A Caixa e o atletismo & 80 \\
\hline 103 & As Loterias e o paradesporto & 81 \\
\hline 104 & Apoio às comunidades carentes & 81 \\
\hline 105 & Simbrasil & 84 \\
\hline 106 & Correspondente bancário & 84 \\
\hline 107 & Logotipo Millennium BCP & 85 \\
\hline 108 & Logotipo da UCC & 85 \\
\hline 109 & Marca imperial & 88 \\
\hline 110 & Marca republicana & 88 \\
\hline 111 & 1861 a 1889 & 89 \\
\hline 112 & 1889 a 1934 & 89 \\
\hline
\end{tabular}




\begin{tabular}{|l|l|c|}
\hline 113 & 1934 a 1970: Autor desconhecido & 89 \\
\hline 114 & 1970 a 1976: Serpro & 89 \\
\hline 115 & 1976 a 1987: Aló́sio Magalhães & 89 \\
\hline 116 & 1976 a 1987: Aloísio Magalhães & 89 \\
\hline 117 & 1987 a 1997: Depto. Com. Soc. CEF & 89 \\
\hline 118 & 1987 a 1997: Depto. Com. Soc. CEF & 89 \\
\hline 119 & 1997 a 2005: NCS Design & 89 \\
\hline 120 & 2005 a hoje: Cauduro Martino & 89 \\
\hline 121 & 2005 a hoje: Cauduro Martino & 89 \\
\hline 122 & Desenho vetorial & 90 \\
\hline 123 & Veja: logotipo com contorno & 90 \\
\hline 124 & Logotipo com degradê, inclusive no contorno (truque) & 91 \\
\hline 125 & Logomarca tipo raster & 91 \\
\hline 126 & Imagem raster ampliada: pontilhada & 91 \\
\hline 127 & Imagem raster reduzida: sem definição & 91 \\
\hline 128 & Logotipo Letraset & 92 \\
\hline 129 & Folha de transferência de letras & 92 \\
\hline 130 & Processo de transferência & 92 \\
\hline 131 & "Alfabeto" das marcas & 92 \\
\hline 132 & A Helvetica, com Aloísio Magalhães & 93 \\
\hline 133 & A Helvetica, pelo Depto. de Comunic. Social da Caixa & 93 \\
\hline 134 & Letra desenhada segundo princípios da Art Déco & 93 \\
\hline 135 & A Informática como linguagem & 93 \\
\hline 136 & Logotipo de site, aplicado em apresentação para projeção & 94 \\
\hline 137 & Exemplos de logos da Caixa sem contornos & 94 \\
\hline 138 & Degradê "tridimensionalizante": difícil visualização em aplicações reduzidas & 95 \\
\hline 139 & Alto contraste cromático: impacto visual mesmo em dimensões mínimas & 96 \\
\hline 140 & Variações monocromáticas & 97 \\
\hline 141 & Estudo cromático & 98 \\
\hline 142 & Logo de Magalhães, versão horizontal & 98 \\
\hline 143 & Logo de Magalhães, versão vertical & 98 \\
\hline 144 & Logo do Departamento de Comunicação Social, versão horizontal & 98 \\
\hline 145 & Logo do Departamento de Comunicação Social, versão vertical & \\
\hline 146 & A busca pelo caminho mais suave & 96 \\
\hline & & 9 \\
\hline
\end{tabular}


Lista de Siglas

\begin{tabular}{|c|c|}
\hline Sigla & Significado \\
\hline ADG & Associação dos Designers Gráficos \\
\hline AI & Ato Institucional \\
\hline ASCII & $\begin{array}{l}\text { American Standard Code for Information Interchange ("código americano padrão para intercâmbio de } \\
\text { informações") }\end{array}$ \\
\hline $\mathrm{BNH}$ & Banco Nacional da Habitação \\
\hline Cbat & Confederação Brasileira de Atletismo \\
\hline CDC & Control Data Corporation (empresa de desenvolvimento de computadores) \\
\hline CD-ROM & Compact Disk - Read Only Medium (“disco compacto - meio apenas para leitura”) \\
\hline CEF & Caixa Econômica Federal \\
\hline $\mathrm{CEO}$ & $\begin{array}{l}\text { Chief of Executive Officer ("chefe do setor executivo"), a pessoa com a mais alta responsabilidade ou } \\
\text { autoridade em uma organização ou corporação }\end{array}$ \\
\hline $\mathrm{CI}$ & Circuito Integrado \\
\hline $\mathrm{CPB}$ & Comitê Paraolímpico Brasileiro \\
\hline CPU & Central Processing Unit ("unidade central de processamento") \\
\hline DNA & DeoxyriboNucleic Acid ("ácido desoxirribonucléico") \\
\hline ENIAC & $\begin{array}{l}\text { Electronic Numerical Integrator Analyzer and Calculator ("calculadora e analisador numérico integrado } \\
\text { eletrônico") }\end{array}$ \\
\hline FGTS & Fundo de Garantia por Tempo de Serviço \\
\hline FSC & $\begin{array}{l}\text { Forest Stewardship Council, a única certificação aceita em todo planeta para produtos criados que } \\
\text { respeitam o meio ambiente }\end{array}$ \\
\hline $\mathrm{HD}$ & Hard Disk ("disco rígido"), principal tipo de memória (permanente) do computador \\
\hline HP & Hewlett Packard (empresa de desenvolvimento de computadores) \\
\hline IBGE & Instituto Brasileiro de Geografia e Estatística \\
\hline IBM & International Business Machines (empresa de desenvolvimento de computadores) \\
\hline INPI & Instituto Nacional da Propriedade Industrial \\
\hline IPEA & Instituto de Pesquisas Econômicas Avançadas \\
\hline LP & Long Play ("longa duração", disco de vinil) \\
\hline MITS & Micro Instruments and Telemetry Systems (empresa de desenvolvimento de computadores) \\
\hline PC & Personal Computer (“computador pessoal”) \\
\hline PC-AT & Personal Computer - Advanced Technology ("computador pessoal - tecnologia avançada") \\
\hline PC-XT & Personal Computer - eXtended Technology ("computador pessoal - tecnologia estendida") \\
\hline PET & Personal Electronic Transactor (“operador pessoal eletrônico") \\
\hline PRC & $\begin{array}{l}\text { Programa de Racionalização e Competitividade, programa reestruturação administrativa da Caixa } \\
\text { (1994) }\end{array}$ \\
\hline
\end{tabular}




\begin{tabular}{|l|l|}
\hline PS/2 & Personal System/2 ("sistema pessoal/segunda versão") \\
\hline Qbasic & $\begin{array}{l}\text { Quick Beginners All-purpose Symbolic Instruction Code ("código rápido de instruções simbólica de uso } \\
\text { geral para principiantes"), linguagem de programação desenvolvida pela Microsoft }\end{array}$ \\
\hline RAM & $\begin{array}{l}\text { Random Access Memory ("memória de acesso aleatório"), principal tipo de memória (volátil) do } \\
\text { computador }\end{array}$ \\
\hline Serpro & Serviço Federal de Processamento de Dados \\
\hline Simbrasil & Sistema de Informações Sócio-Econômicas dos Municípios Brasileiros \\
\hline TRS & Tandy Radio Shack (empresa de desenvolvimento de computadores) \\
\hline UCC & Universidade Corporativa Caixa \\
\hline Univac & UNIVersal Automatic Computer ("computador automático universal”) \\
\hline
\end{tabular}




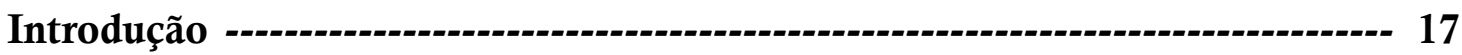

Marcando presença no mundo --- 18

Marcando o alvo --_- 19

Marcando o caminho --- 21

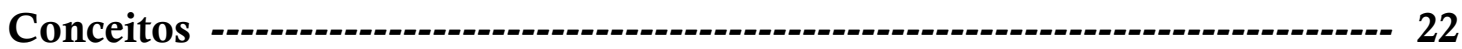

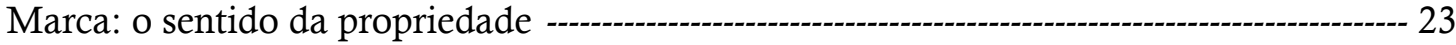

Terminologia ------- 26

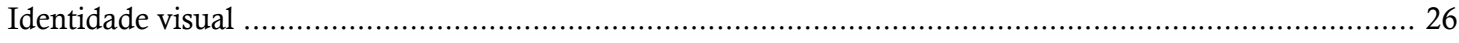

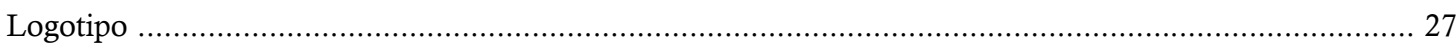

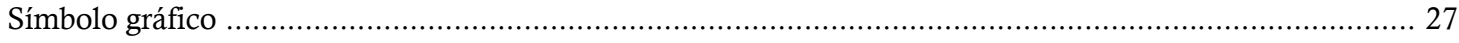

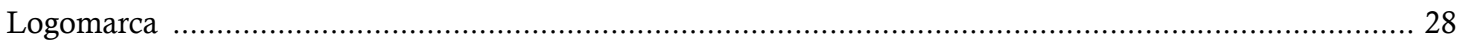

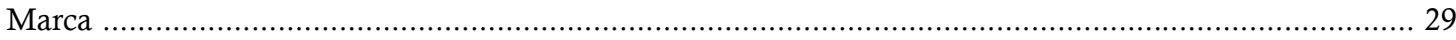

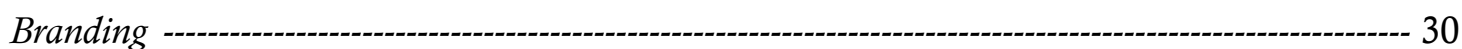

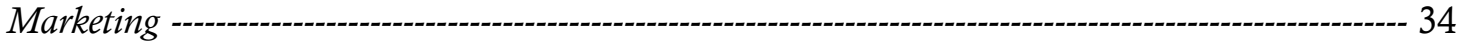

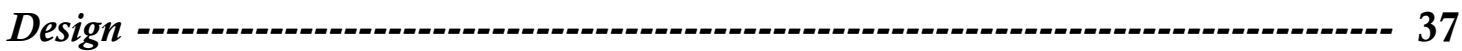

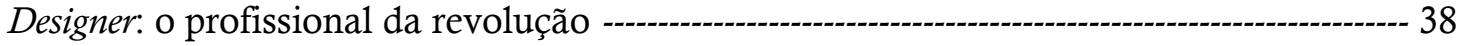

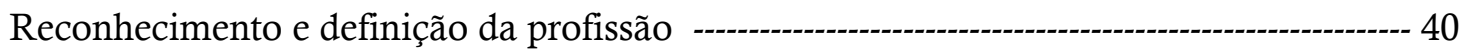

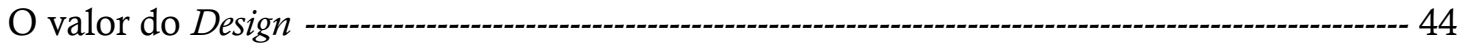

Design computadorizado --- 47

Design manual --_-_-_----_- 53

Princípios do Design --_- 56 


\section{Computador}

A nova ferramenta 59

Era uma vez... 60

As quatro gerações de computadores

O início da "era moderna" 67

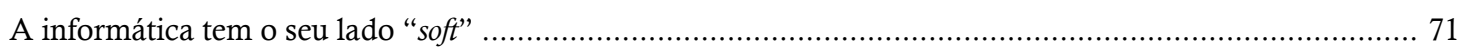

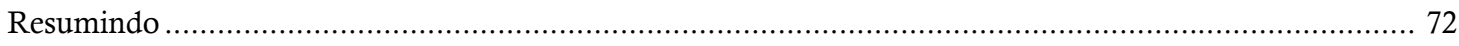

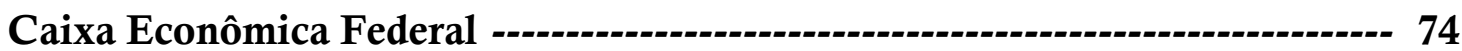

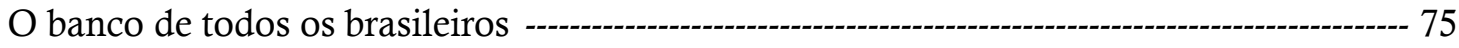

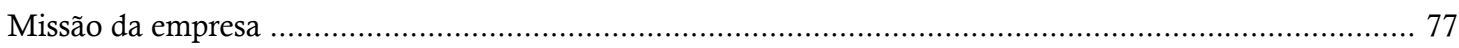

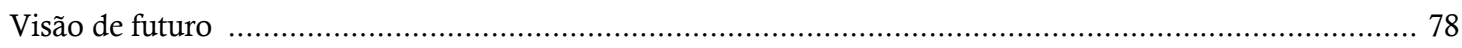

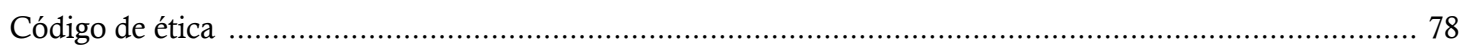

Caixa Cultural ---------------------------------------------------------------------------------------------------------- 79

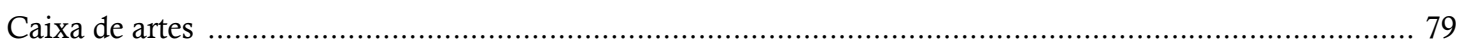

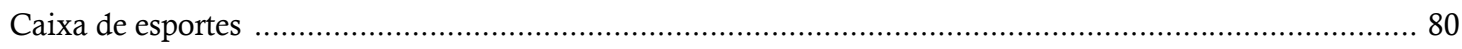

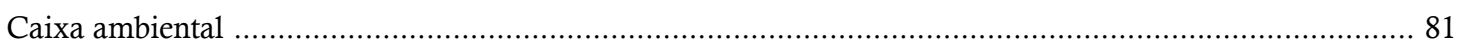

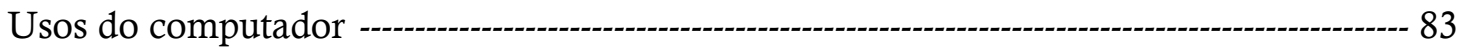

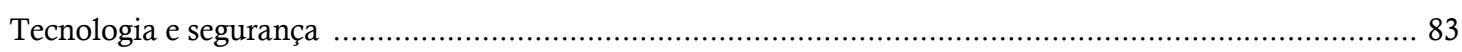

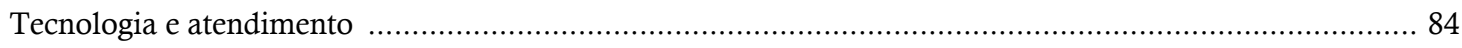

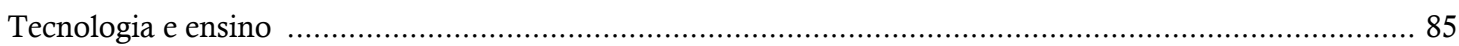


Análise e Conclusão

Aplicações da marca 88

Evolução da marca corporativa 89

A influência do computador 90

Uso de desenho vetorial 90

Uso de fontes de letra 92

Uso de traços simples 93

Uso de cores 95

Testes de aplicação 96

A contribuição da ferramenta computador 98

Um mundo de marca maior 99

Referências 100

Livros 101

Sites 106

Apêndice 108

WebForum 109 


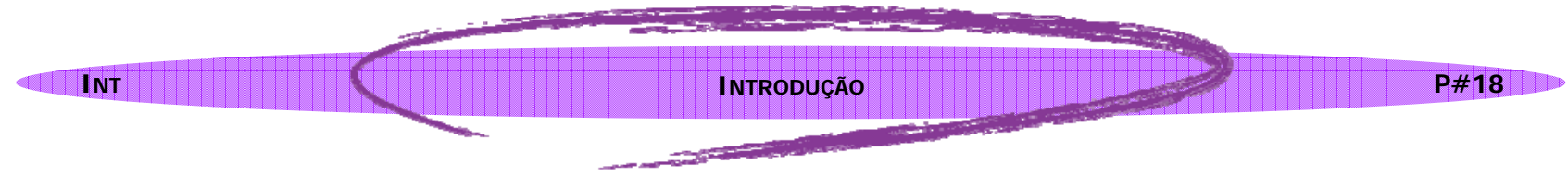

Marcando presença no mundo
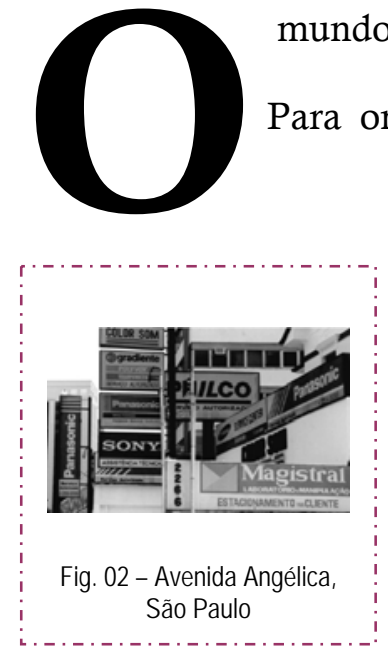

mundo de hoje parece um grande supermercado!

Para onde olhamos, especialmente nas metrópoles, visualizamos marcas, de todos os tipos, formatos, tamanhos, cores e gostos. Mantendo ainda a analogia, temos os bons e os maus produtos, as embalagens agradáveis e as nem tão atraentes, os preços exorbitantes e as pechinchas. E marcas, marcas, marcas e mais marcas.

O aumento significativo na produtividade industrial, especialmente no período pósGrande Depressão, gerou uma expressiva competição entre empresas de atuação local: era preciso crescer para sobreviver. E o mundo cresceu: surgiram as grandes corporações, 
desenvolveram-se novas tecnologias, ampliaram-se mercados e riquezas. Mas existe também o lado sombrio deste mundo brilhante: fome, exploração, concentração de renda, desemprego.

Independentemente do ângulo que se analise, é fato que o mundo mudou durante o século passado: você escolhe a marca de suas meias, procura o desenho específico de um isqueiro e pesquisa a tecnologia de um ferro de passar roupas antes de adquiri-lo! Algo impensável para nossos avós, nos é corriqueiro. E nos preocupamos cada vez mais com as escolhas do dia-a-dia. Conceitos como design, marketing, tecnologia de ponta... não são tão assustadores como antes. E o computador já está presente em nossos lares, modificando a nossa rotina diária, adquirido nas melhores lojas do ramo. Ou no supermercado mais próximo...

\section{Marcando o alvo}

Esta dissertação busca estudar como o uso da tecnologia, através de sua mais versátil ferramenta, o computador, vem interferindo no desenvolvimento de marcas nos últimos anos, após a introdução e, especialmente, a popularização das ferramentas informatizadas de produção de elementos visuais, conhecidas como "computação gráfica". Este estudo será feito utilizando, como principal objeto de análise, a imagem corporativa da Caixa Econômica Federal, hoje o maior banco habitacional latino-americano.

Este estudo se justifica pela mudança de paradigma no processo criativo de peças gráficas ocasionada pela introdução do computador nos escritórios de Design. A criação em Comunicação Visual, até o final do século XX, se restringia a trabalhos de desenho técnico, seguido de recorte, montagem e colagem de elementos (processo conhecido como paste-up), que juntos, e em determinada posição, formavam a marca ou imagem corporativa de uma determinada empresa. 
A popularização do computador como ferramenta de desenvolvimento gráfico tornou mais fácil e prático o trabalho dos designers, permitindo novas experiências e, mais importante, experimentações menos trabalhosas. Com a inserção da computação gráfica, a partir na segunda parte do século passado, mas popularizada após a década de 1990, as antigas restrições decorrentes do trabalho de paste-up deixaram de existir, dando espaço a outras novas limitações, como o abandono do traço livre, leve, orgânico, em função da dificuldade ou inabilidade do profissional de design gráfico em dominar a nova ferramenta.

Efetivamente, o computador requer do designer uma prática, ou uma dedicação no desenvolvimento de seu "manejo", que muitas vezes é desdenhada, comprometendo os resultados obtidos. Desta maneira, ao contrário de libertar, o computador acaba por viciar e "pasteurizar" a criação do programador visual.

O estudo da influência desta ferramenta na "história visual" de uma marca estabelecida (Caixa Econômica Federal) busca avaliar a computação gráfica e sua influência no processo de desenvolvimento da imagem corporativa, bem como seus resultados obtidos.

Serão pesquisadas as mudanças gráficas, plásticas e de aplicação da marca da Caixa Econômica Federal entre os anos de 1861 e 2005 e identificadas as modificações influenciadas pelo computador, destacando a contribuição desta ferramenta tecnológica neste processo.

O método utilizado será o de coletar e analisar as diferentes marcas utilizadas pela Caixa (de 1861 a 2005), identificar e catalogar as marcas que sofreram a influência do computador e analisar a causa e a pertinência destas mudanças.

Esta dissertação divide-se em cinco capítulos básicos, sistematizados de forma a compreender o escopo das áreas enfocadas. 
O primeiro [Conceitos] discute parte da terminologia utilizada nesta área, especialmente os termos cujo conhecimento é imprescindível para o entendimento do presente trabalho: Identidade visual, Logotipo, Símbolo gráfico, Logomarca, Marca, Branding e Marketing.

O capítulo subseqüente [Design] mostra o histórico da profissão de designer, o valor que o Design traz ao produto e o reconhecimento que a área vem conquistando, discorre sobre as vantagens e desvantagens do design computadorizado e do manual, terminando com um breve exame sobre princípios do Design.

O trabalho segue pelo terceiro capítulo [Computador] apresentando breve histórico do desenvolvimento do microcomputador, com termos e objetos que, embora de uso corriqueiro, não se conhecem suas origens.

O quarto capítulo [Caixa Econômica Federal] traz um relato da história centenária da Caixa, mostrando os principais fatos que marcaram esta instituição bancária.

No último capítulo [Análise e Conclusão], são descritos os elementos que sofreram influência da ferramenta estudada.

\section{Marcando o caminho}

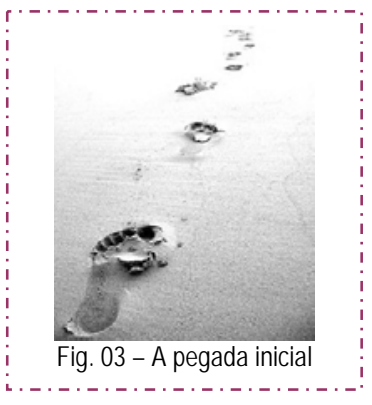

O primeiro passo é o mais importante em uma longa jornada: dá início ao processo e direciona o caminho a ser percorrido. E o que se pretende aqui é que esta dissertação possa orientar outros profissionais da área no desenvolvimento de marcas: imprimir a pegada inicial e esperar que esta indique uma trilha mais suave e prática. 


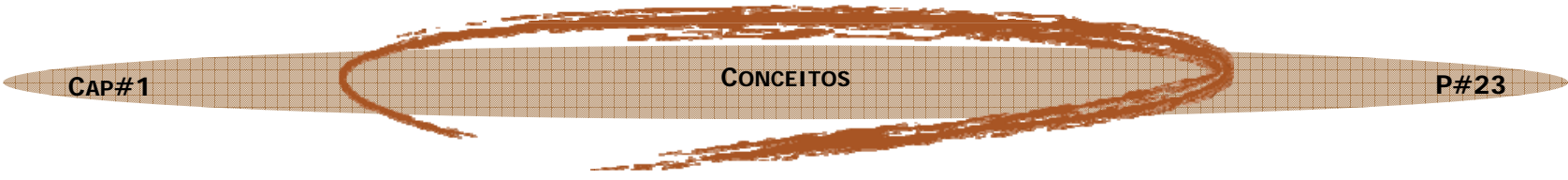

Marca: o sentido da propriedade

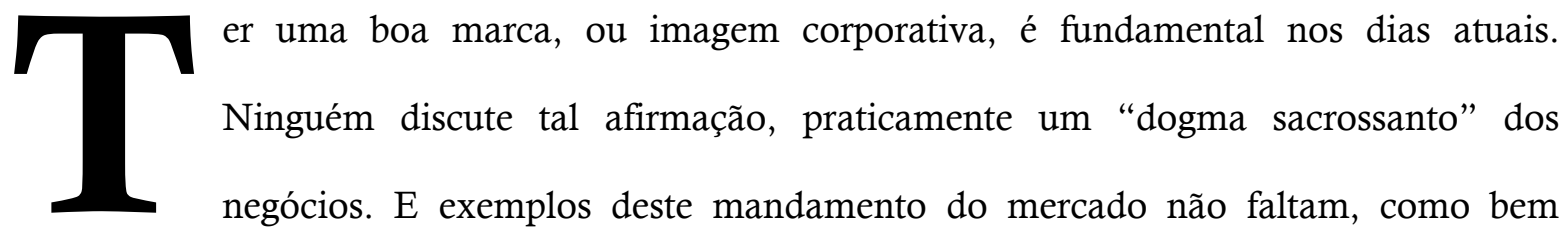

ilustra o especialista David D'Alessandro:

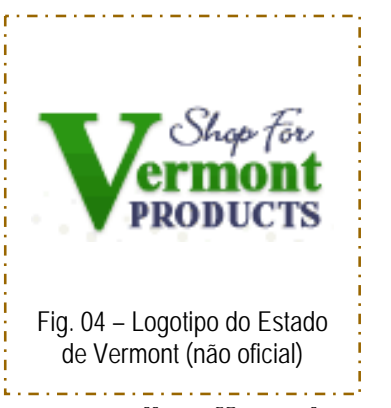

"Mais do que qualquer outro conceito de hoje, a idéia de 'marca' infiltrou-se na cultura. Uma estrela de cinema como Tom Hanks agora fala abertamente sobre a importância de proteger a marca Tom Hanks. 0 Estado de Vermont considera que também é uma marca e está desenvolvendo regulamentos para impedir que empresas de fora do Estado se apropriem indevidamente do sinete 'Vermont'. Quando o New York Times perguntou ao exorcista oficial da Catedral de Notre Dame, alguns anos atrás, por que estava tirando clientes de toda a França quando eles poderiam ser tão bem exorcizados em suas igrejas locais, o padre Claude Nicolas respondeu deste modo: 'Evidentemente, pensam que Notre Dame é melhor. Naturalmente tem uma marca definida'” (D'ALESSANDRO, 2002, P. XVI).

Em nome desta "cultura de marcas", bilhões de dólares são gastos anualmente em todo o globo. Se a importância do conceito é clara, o processo de desenvolvimento da marca não 
poderia ser mais desprezado, aviltado: nada é tão mal compreendido como a questão de como usá-la corretamente. Fusões de empresas, reengenharia de negócios, reestruturação de marcas, reformas e adequações... muitas vezes são planejados com base em premissas falhas ou equivocadas, caminho certo para o fracasso retumbante. E caríssimo, há de se acrescentar...

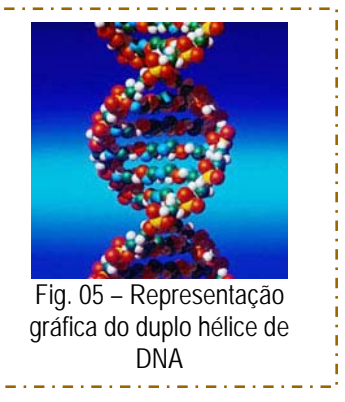

A marca, portanto, não é mais tão somente um símbolo de propriedade: ela é parte intrínseca do produto. Tudo funciona como um "DNA de negócios": mude um único "gene" no duplo hélice empresa-consumidor (como, por exemplo, o "gene" da marca, do ponto de venda, da comunicação...) e o "organismo" todo pode sofrer uma mutação, podendo, até, vir a "falecer".

Neste intrincado quebra-cabeças, a marca é das peças mais importantes: permeia toda a produção, traz visibilidade, passa confiança, estabelece identidade com o consumidor, transmite glamour, posiciona produtos... dá alma ao negócio. É ela quem faz a linha de frente de um negócio, é a primeira, e a mais impactante, forma de identificar uma empresa.

Adrian Frutiger define a importância da marca:

"Numa economia caracterizada pela concorrência em constante crescimento, a anonimidade visual torna-se fatal. 0 consumidor não confia mais no produto anônimo, nem no serviço despersonalizado. Atualmente, a criação de uma identidade é cada vez mais necessária para se conquistar e manter um lugar no mercado" (FRUTIGER, 2001, P. 303).

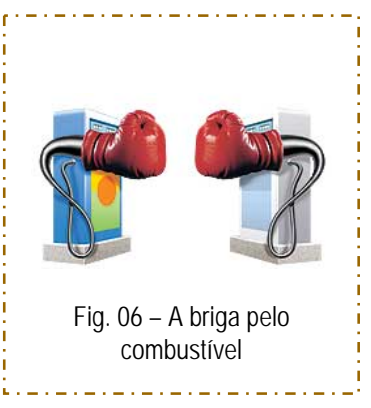

Um exemplo simples do que Frutiger afirma, no Brasil, são os postos de gasolina sem "bandeira" definida ou de marcas pouco conhecidas (chamados "bandeira branca"): muitos motoristas evitam seus serviços, por considerarem seus produtos de baixa qualidade, temendo o abastecimento com combustível adulterado, entre outros

problemas. 
Contudo, quando uma marca é planejada com coerência e bem desenvolvida, ela é " $a$ coisa mais próxima que temos de uma linguagem internacional, reconhecida e compreendida em muito mais lugares do que o inglês" (KLEIN, 2003, P. 22) ou qualquer outro idioma: pode-se sempre encontrar e

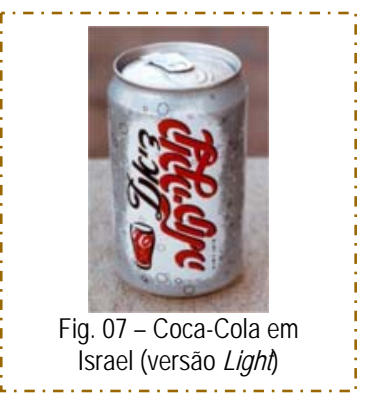
consumir uma Coca-Cola ou um BigMac em qualquer parte do mundo, sabendo-se ou não o idioma ou o alfabeto local, seja no Brasil, na China, na Rússia ou na Arábia Saudita...

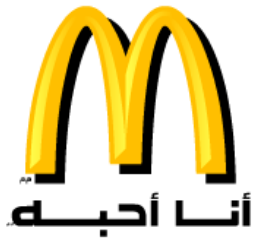

Fig. 08 - McDonalds no Reino do Bahrein

Em outras palavras, a marca é universal: transpõe barreiras culturais, lingüísticas, ideológicas... E saber desenvolver uma marca forte é estar um passo a frente da concorrência no competitivo mercado atual. 
Como acontece com muitos dos mais interessantes assuntos que se possa discutir, não existe unanimidade no que se refere ao desenvolvimento de marcas, em especial quanto à terminologia técnica empregada no estudo do tema.

Há muita controvérsia na questão das definições de termos como logotipo e logomarca, dentre numerosos outros. Não é pretensão de o presente trabalho estender-se por esta análise, tampouco esgotar tal assunto. Outrossim, para que haja a devida compreensão, necessita-se acordar uma quantia mínima de termos relacionados com este tema: Identidade Visual, Logotipo, Símbolo Gráfico, Logomarca e Marca.

É necessário reforçar: o sentido de tais definições é em direção de estabelecer uma comunicação clara, de modo que haja uma única compreensão daquilo que aqui se expõe. Os conceitos que se seguem são, pois, verdadeiros para o presente estudo, e tão somente para ele.

\section{Identidade visual}

A Associação dos Designers Gráficos - ADG define Identidade Visual como "conjunto sistematizado de elementos gráficos que identificam visualmente uma empresa, uma instituição, um produto ou um evento, personalizando-os, tais como um logotipo, um símbolo gráfico, uma tipografia, um conjunto de cores" (ADG BRASIL, 2004, P. 180).

O termo Identidade Visual será aqui utilizado como forma de reconhecimento ou representação visual de algo, de maneira genérica, independentemente de qual seja tal forma (idéia geral); quando esta representação se referir a uma empresa ou instituição, a expressão Identidade Visual Corporativa poderá ser empregada, com o mesmo significado. 
Eis um dos termos bastante controversos quanto a sua definição: Logotipo ou, simplemente, Logo. Sua origem etimológica vem do grego Lógos (significado, conceito, idéia) e Týpos (modelo, sinal), significando algo como "símbolo visível de uma idéia"; em outras palavras, a identificação visual de algo (neste caso, de uma empresa).

Para alguns autores, Logotipo é a identificação visual de uma empresa específica ou um indivíduo. Para outros, como o designer Pedro Guitton, o termo significa "uma solução tipográfica, a escrita do nome da empresa" (GUITTON, 2001, P. 7). Para a ADG, é a "marca comercial de uma empresa, constituida por uma ou mais palavras ou por um grupo de letras grafadas em desenho e estilo característicos" (ADG BRASIL, 2004, P. 183).

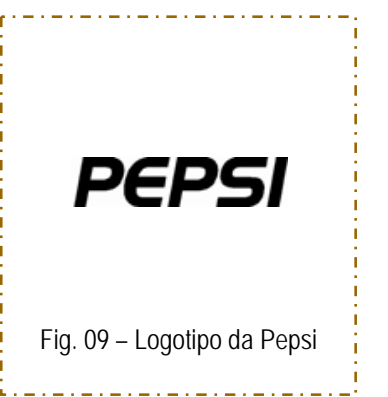

\begin{abstract}
Nesta dissertação, considera-se a definição de Logotipo como a identidade visual constituída exclusivamente por caracteres tipográficos (letras e números, principalmente).
\end{abstract}

\title{
Símbolo gráfico
}

No grego, Symbolon significa "o que representa ou substitui algo, por analogia" e Grafikos é "uma representação visual de algo", resultando em "analogia visual, desenho representativo".

Conceituado pela ADG como "desenho característico destinado a funcionar como elemento de identidade visual de uma empresa, organização, produto, serviço ou evento" (ADG BRASIL, 2004, P. 193), podendo ser abstrato ou figurativo, a mesma idéia pode ser utilizada com nomenclatura um pouco divergente: sinal gráfico, signo gráfico, grafismo ou simplesmente símbolo. 

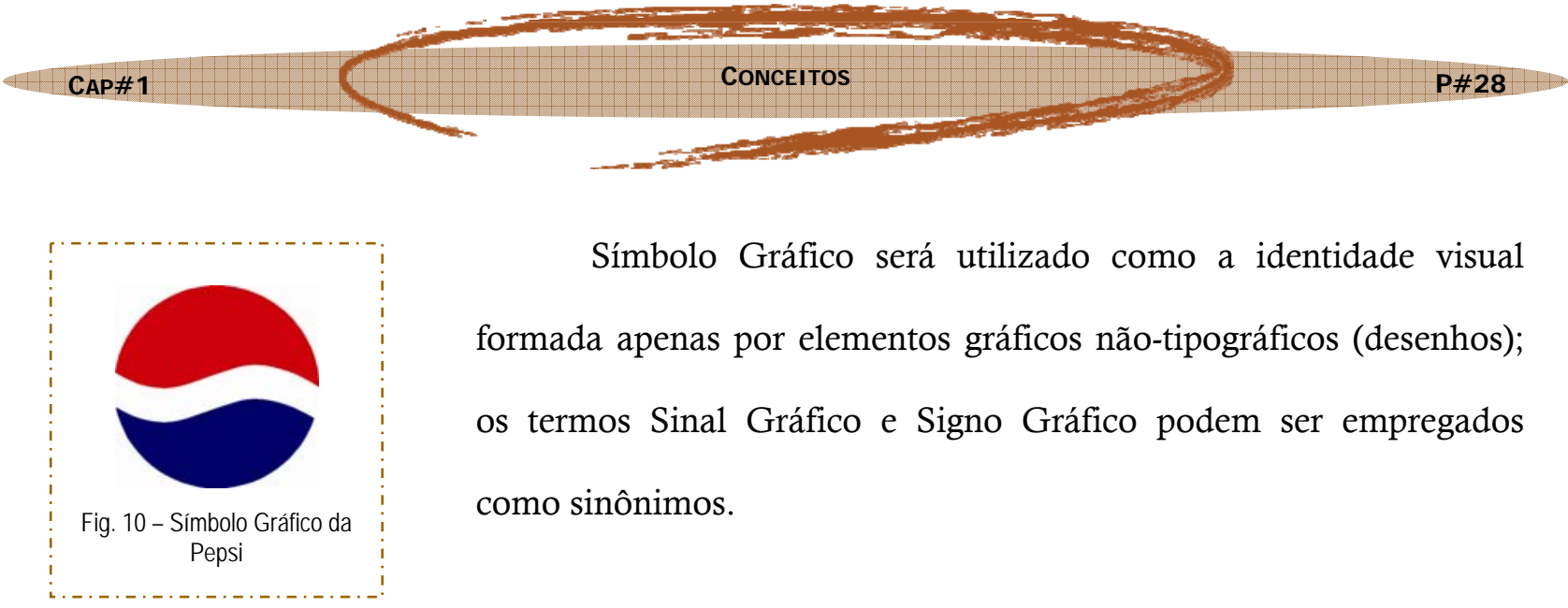

\begin{abstract}
Símbolo Gráfico será utilizado como a identidade visual formada apenas por elementos gráficos não-tipográficos (desenhos); os termos Sinal Gráfico e Signo Gráfico podem ser empregados como sinônimos.
\end{abstract}

Logomarca

O termo "Logomarca" também pode ser considerado um dos mais polêmicos na área de design gráfico. Um neologismo utilizado por profissionais brasileiros de Publicidade e Marketing, acabou "incorporado" ao dia-a-dia dos designers. Em sua origem, combina o Lógos grego (significado, conceito, idéia) e o Markjan lombardo (sinal, significado): "significado do significado", motivo pelo qual é combatido por certos autores, não sendo definido por nenhum dicionário moderno da língua portuguesa.

A ADG emprega efetivamente o termo e o define como a "identificação genérica habitualmente utilizada, sobretudo no meio publicitário, para sinais diversos de um programa de identidade visual, como logotipo, símbolo e marca" (ADG BRASIL, 2004, P. 183); Guitton também o aceita, considerando-o a união de logotipo e símbolo gráfico (GUITTON, 2001, P. 7). O dicionário participativo on line Wikipedia (HTTP://PT.WIKIPEDIA.ORG/WIKI/LOGOMARCA, ACESSADO EM 23 DE MAIO DE 2006) é uma das únicas enciclopédias a definir o verbete, ainda que destacando a imprecisão do termo. Existe uma discussão interessante no site WebFórum (HTTP://FORUM.WMONLINE.COM.BR/INDEX.PHP?SHOWTOPIC=94545, ACESSADO EM 30 de MAIO de 2006; VIDE APÊNDICES, PÁGINA XXX), de autoria de Gilberto Alves Jr., versando sobre a polêmica deste termo e outros correlatos. 


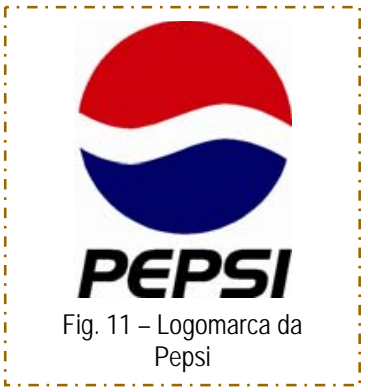

Ainda que controversa e combatida, a palavra Logomarca será aqui empregada em relação à identidade visual formada por elementos gráficos e tipográficos (desenhos e textos), seguindo a definição de Pedro Guitton.

\section{Marca}

Segundo Aurélio Buarque de Holanda, marca é o "símbolo gráfico (logotipo, emblema ou figura) que identifica ou representa uma instituição, uma empresa, etc." (FERREIRA, AURÉLIO BUARQUe DE

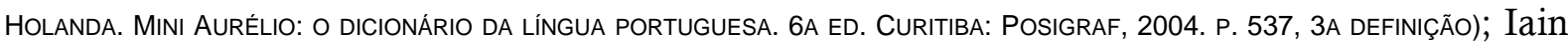
Ellwood define como "conjunto de características que proporcionam valor agregado a um produto ou serviço além de seu beneficio tangível" (ELLWOOD, 2004, P. 353); para a ADG, é o "nome, símbolo gráfico, logotipo ou combinação destes elementos, utilizado para identificar produtos ou serviços de um fornecedor/vendedor e diferenciá-los dos demais concorrentes. [...] O mesmo que brand" (ADG BRASIL, 2004, P. 184); Pedro Guitton cita que é a forma como "a empresa se vê e quer ser vista pelo mercado" (GUITTON, 2001, Р. 7); Marcos Cobra define como "um nome, um sinal, um símbolo, ou design, ou uma combinação de tudo isso, com o objetivo de identificar produtos ou serviços de um vendedor ou grupo de vendedores e diferenciá-los de seus concorrentes" (COBRA, 1997, Р. 207).

Como já citado no tópico sobre Logomarca, sua etimologia se refere a "sinal, significado", o que segue de encontro com a definição de Guitton.

Aqui, utilizar-se-á o termo no sentido amplo, como identidade de uma empresa, produto, instituição ou indivíduo, independentemente se esta identificação seja sob a forma visual, textual, ideológica ou qualquer outra. 
Os americanos dizem, em relação ao que consideram "Football”, que um jogo não é uma questão de vida ou morte, é muito mais importante que isso. A marca de uma empresa também. A exemplo de alguns dirigentes esportivos brasileiros, que afirmam ser um pênalti tão importante que deveria ser cobrado pelo presidente do clube, autores como Des Dearlove e Stuart Crainer afirmam que a marca de uma empresa deveria ser gerida pela sua autoridade máxima, o presidente, diretor, CEO ou qual seja o título aplicável.

O gerenciamento de marcas, ou branding, pode ser considerado uma das atividades de planejamento estratégico mais importante na atualidade. $O$ faturamento de escritórios especializados nesta área de atuação só é superado pela responsabilidade que o mesmo deve apresentar na criação e manutenção de uma marca empresarial.

O branding une, no processo de construção de uma marca, as disciplinas de Marketing e Design: a primeira se responsabiliza pelo planejamento e o Design define a expressão visual da marca criada.

"As marcas são a principal defesa contra a competição de preço. Marcas fortes criam mais confiança e conforto e uma imagem de melhor qualidade do que marcas menos conhecidas. As pessoas estão dispostas a pagar um preço mais elevado pelas marcas mais fortes. [...] As empresas estão percebendo que a marca é sua única esperança de ganhar atenção e respeito num mercado cada vez mais competitivo. Uma marca é uma promessa de valor. Ela se torna o conceito organizador para todas as atividades da empresa que giram em torno da marca" (KOTLER, 2005, P. 65).

Kotler ainda afirma que a marca é construída, inicialmente, pela publicidade, mas só se mantém forte por seu próprio desempenho. É possível, com uma marca forte, vender mais pelo mesmo preço ou cobrar mais pela mesma quantidade, mas nenhuma empresa, por melhor que seja sua imagem, consegue sustentar um produto ruim: a marca não se mantém mascarando a baixa qualidade de um produto. 


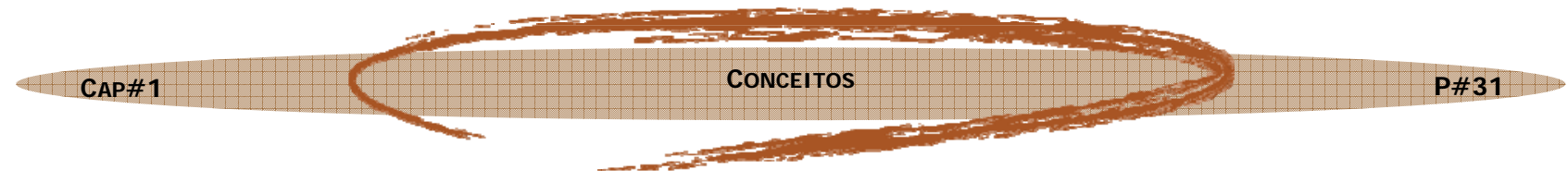

\section{Dearlove e Crainer vão além:}

"Nesta nova era, as marcas são dirigidas pelos consumidores. São psicológicas tanto quanto físicas. As marcas se relacionam ao que se sente e pensa. 'Uma marca é uma promessa e, no final, você tem que cumpri-la. Um produto é a materialização da verdade de uma promessa. [...] Não há diferença entre o que você vende e aquilo em que acredita', diz o futurólogo Watts Wacker. Vender é acreditar. Mais importante, as pessoas compram aquilo em que confiam e acreditam, e estão dispostas a pagar um preço adicional pelo produto. No final, a marca funciona porque a crença vende" (DEARLOVE; CRAINER, 2000, P. XVIII).

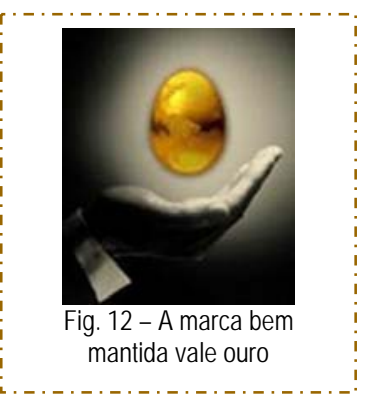

Mas os mesmos autores alertam para a importância do trabalho bem feito, especialmente pela sensibilidade do assunto em pauta, detalhando o paradoxo do branding: "As marcas precisam renascer ou desaparecem; mas, se você mudá-las demais, matará a galinha dos ovos de ouro. [...] Você deve mudar as marcas para manter sua vitalidade; mas, se mudá-las demais, afastará seus clientes fiéis. Não existe uma marca a prova de bala. $O$ gerenciamento de marca é uma arte sutil e misteriosa" (DEARLOVE; CRAINER, 2000, P. XXIV).

A designer carioca Adriana Costa e Silva destaca outro tópico de suma importância para o branding - a escolha do nome da marca:

"Escolher um bom nome é algo até relativamente fácil. 0 difícil é alguém já não estar utilizando e tê-lo registrado no INPI (Instituto Nacional da Propriedade Industrial).

De uma maneira geral, os nomes com menos chance de registro são os menos convencionais. Porém, devemos aceitar que os nomes não-convencionais provavelmente estão desprovidos de associações, assim como devemos esperar que os sentimentos em relação a esses nomes só surgirão a partir da massificação dos conceitos, o que só acontecerá a partir do posicionamento e do uso inteligente da propaganda e do marketing.

Um bom nome é aquele que facilita a associação de qualquer sinal gráfico pelo consumidor, simplifica o processo de memorização e compra, promove a identidade da marca e evoca sentimentos de confiança, segurança, durabilidade, status e exclusividade. Felizmente, a média dos nomes adequados é superior à média dos impróprios. [...]

0 nome, porém, não é suficiente para identificar a empresa. É necessária uma identidade visual que traduza os benefícios oferecidos pela corporação aos consumidores (nas embalagens, papelaria, letreiros, folders, homepages,...). Um grande número de empresas sabe disso e tenta se atualizar e evoluir o tempo todo. No entanto, são raras as que conseguem realmente se distinguir das concorrentes" (COSTA E SILVA, 2002, P. 20). 


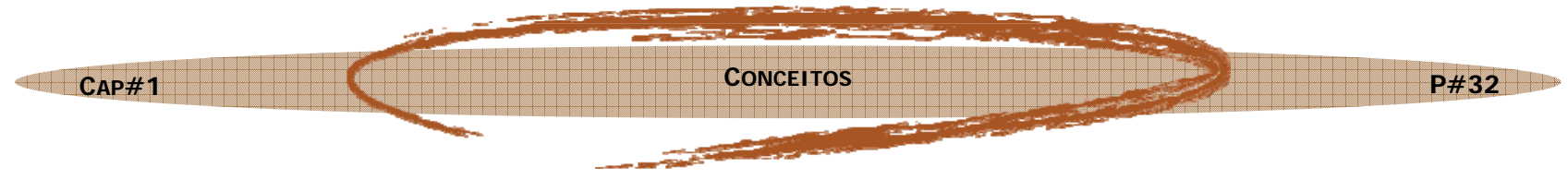

Philip Kotler complementa o destaque de Adriana, identificando três passos principais para a construção de uma marca forte:

1. Escolha um nome de marca;

2. Desenvolva associações e promessas fortes para esse nome de marca;

3. Administre todos os contatos do cliente com a marca, de modo que esses contatos atendam ou superem as expectativas geradas em relação a ela (KOTLER, 2006, P. 76).

Al e Laura Ries são ainda mais taxativos:

"Uma companhia pode gastar centenas de milhões de dólares para desenvolver um novo produto e depois dar a esse produto um nome de marca que praticamente garante seu fracasso. A inovação sozinha nunca é suficiente.

Juntamente com a inovação, uma companhia precisa de marketing para assegurar 0 sucesso e a sobrevivência da marca. A essência de um bom programa de marketing é ter um excelente nome" (RIES; RIES, 2006, P. 4).

Marcos Cobra resume alguns tópicos importantes no que se refere ao valor do nome da marca bem desenvolvido:

"A verdade é que se a marca não faz a venda, ajuda, e muito, a vender. À medida que uma marca ajuda a distinguir e notabilizar um produto, mais depressa ele é vendido.

[...] E a retenção do nome na memória do consumidor é fator decisivo no momento de escolha. Com efeito, uma das características importantes é a fácil memorização. As siglas, os símbolos, as cores e os logotipos das marcas (LOGO-MARCAS) são de grande influência no grau de atenção que é concedido ao produto pelos observadores. [...]

A questão é, pois, usar a criatividade no nome da marca e nas suas formas de representação gráfica para que ela estimule o consumidor a comprar" (COBRA, 1997, P. 208).

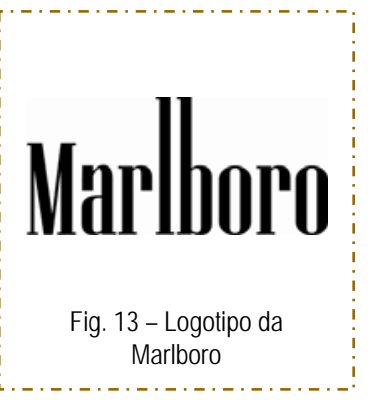

Naomi Klein faz um completo relato da evolução do branding da segunda metade do século XIX aos dias atuais, incluindo o caso "Sexta-feira de Marlboro" (2 de abril de 1993), quando a Phillip Morris anunciou um corte de $20 \%$ no preço de seu produto-chefe para concorrer com cigarros mais baratos, sinal, identificado pelo mercado, da descrença de uma lenda no mundo de negócios no conceito "Marca de Prestígio", 


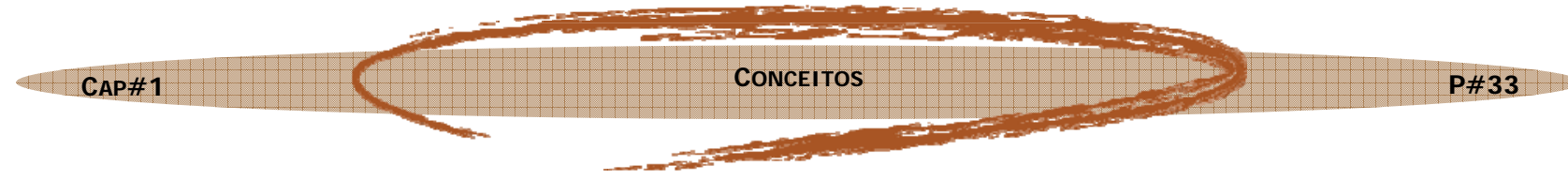

forçando uma queda nas ações de empresas importantes, como Heinz, Quaker, Coca-Cola, Pepsi, Procter\&Gamble e RJR Nabisco, e levando o pânico a Wall Street (CF. KLEIN, 2003, P. 27-50).

Por fim, Klein termina o relato mostrando a importância do branding nos negócios atuais:

"Nos últimos seis anos, assombradas pela experiência de quase morte da Sexta-feira de Marlboro, as corporações globais subiram no trem da marca com o que só pode ser descrito como fervor religioso. Nunca mais o mundo corporativo se inclinaria para rezar diante do altar do mercado de produtos. De agora em diante, venerariam somente imagens de mídia estampadas. Ou, para citar Tom Peters, o homem da marca: 'Marca! Marca! Marca!!! É essa a mensagem [...] para o final dos anos 90 e para 0 futuro"" (KLEIN, 2003, P. 50). 
Este também é um termo que não apresenta unanimidade entre os estudiosos especializados nesta área. Philip Kotler, um dos mais consagrados autores acerca do tema, define marketing como "o conjunto de atividades humanas que tem por objetivo facilitar e consumar relações de troca" (KOTLER, 2000, P. 36) em uma das primeiras publicações dedicadas ao assunto (1967); o conceito mais importante, segundo o próprio Kotler, centra-se no termo "troca".

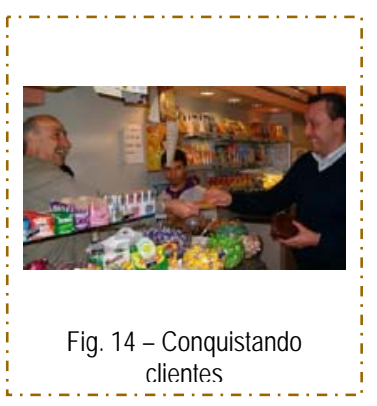

Porém, em suas obras mais recentes, Kotler apresenta outras definições possíveis: "a arte de descobrir oportunidades, desenvolvê-las e lucrar com elas" (1999) (KOTLER, 2006, P. 54), "a ciência e a arte de conquistar e manter clientes e desenvolver relacionamentos lucrativos com eles" (1999) (KOTLER, 2006, P. 155) Ou ainda "a ciência e a arte de explorar, criar $e$ proporcionar valor para satisfazer as necessidades de um mercado-alvo com rentabilidade" (2005) (KOTLER, 2005, P. 13).

Autores brasileiros, como Edmundo Brandão Dantas e Marcos Cobra, preferem discorrer sobre tal polêmica que criar um novo conceito (CF. COBRA, 1997, P. 23-35 E DANTAS, 2005, P. 16-45); O próprio Cobra apresenta dez definições diferentes, inclusive com autores se corrigindo ou ampliando suas definições, ao longo de quase 30 anos (entre 1960 e 1997) (COBRA, 1997, P. 27).

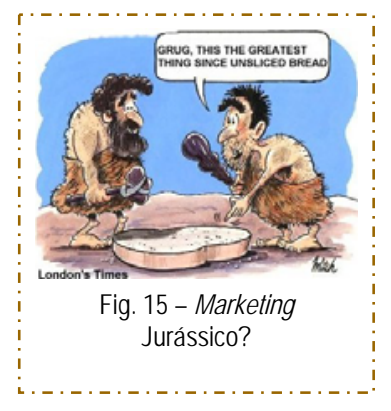

O próprio termo já se tornou corriqueiro: marketing de relacionamento, endomarketing, marketing de redes, telemarketing... O termo está na moda: há um tipo de marketing para qualquer área que analisemos; porém, seu emprego nem sempre é feito de forma 
correta. Frases como "isso é puro marketing", "é uma jogada de marketing" ou "o marketing agressivo das operadoras de celular" não são incomuns, associando uma imagem de engodo a esta disciplina.

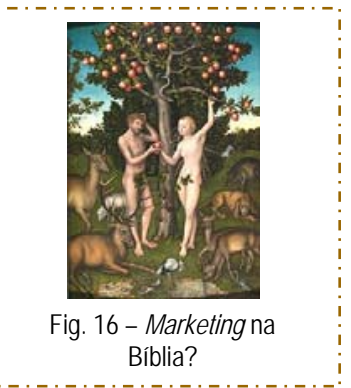

Infelizmente, muitos especialistas nesta área contribuem para este desvio: quase todos brincam com a idéia de que a serpente do paraíso, num primeiro momento, e Eva, num segundo, utilizaram conceitos de Marketing para influenciar seu "cliente" a consumir a "maçã da árvore da vida"! (BíbLIA SAGRADA: GÊNESIS 3, 1-13)

Marketing não é desonestidade! É uma filosofia de negócios voltada ao atendimento de necessidades do consumidor como forma de gerar lucros a determinada empresa. E consumidor enganado não adquire produtos de empresas desonestas! Como já visto no tópico sobre branding, "uma marca é uma promessa e, no final, você tem que cumpri-la. Um produto é a materialização da verdade de uma promessa. [...] Não há diferença entre o que você vende e aquilo em que acredita"' (WATTS WACKER, APUD DEARLOVE; CRAINER, 2000, P. XVIII).

As teorias de Marketing também têm evoluído com o tempo neste sentido: o foco principal de atuação, que antes era voltado para a empresa (1964 - os 4 P de Eugene Jerome McCarthy: produto, preço, promoção e ponto de venda) (COBRA, 1997, P. 28-31), hoje é direcionado ao usuário (1993 - os 4 C de Robert Lauterborn: cliente, custo, comunicação e conveniência) (COBRA, 1997, P. 31). "Sua Majestade, o Consumidor," detém o controle do processo de compra.

Aqui, surge uma outra polêmica nesta área: Marketing cria ou não necessidades? Alguns especialistas dizem que sim, outros argumentam que tal necessidade estaria latente, e só seria "despertada" pelo Marketing. Existem também os que afirmam que a necessidade é inerente ao ser humano, e o Marketing cria e satisfaz apenas o desejo atrelado a tal necessidade. Em outras 

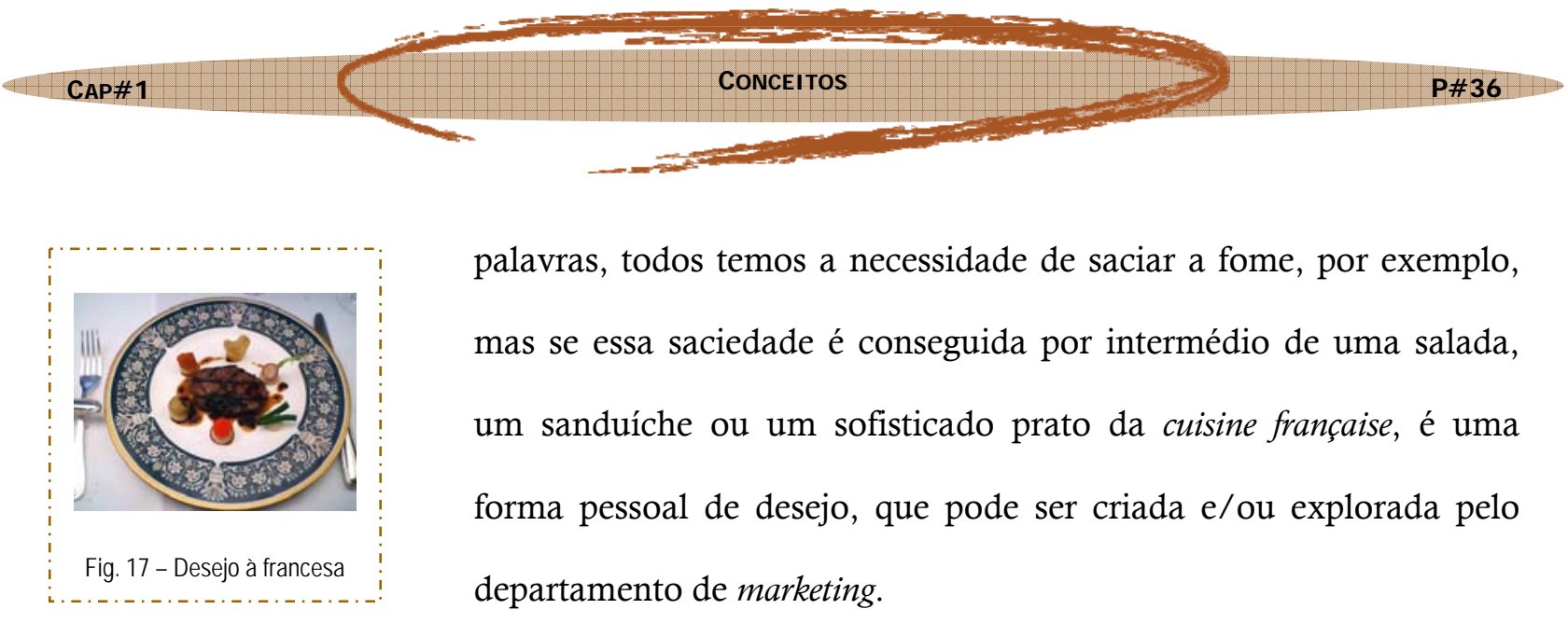

palavras, todos temos a necessidade de saciar a fome, por exemplo, mas se essa saciedade é conseguida por intermédio de uma salada, um sanduíche ou um sofisticado prato da cuisine française, é uma forma pessoal de desejo, que pode ser criada e/ou explorada pelo departamento de marketing.

Chegamos, então, a mais uma discussão infindável: o Marketing deve ser restrito a um departamento ou setor da empresa ou ser espalhado por todas as áreas da mesma? Não há unanimidade: uns defendem que a restrição é primordial, outros afirmam que os conceitos de Marketing devem permear a empresa toda; e há aqueles que defendam a especialização do profissional de marketing, enquanto existem os que argumentam que qualquer pessoa de bom senso pode atuar na área, com conhecimento específico ou não.

Em resumo, o profissional de marketing, dotado de formação específica ou apenas munido de bom senso e uma observação atenta às necessidades de seu consumidor, deve utilizar todas as formas lícitas e éticas de despertar e atender os desejos de seu consumidor com os produtos de sua empresa, garantindo que o consumo se repita de forma satisfatória e que possa criar fidelidade entre seu cliente e sua empresa, resultado de uma relação benéfica para ambas as partes e que promove o equilíbrio entre produção (empresa) e demanda (consumidor). Isso, de maneira abrangente, seria uma definição de Marketing.

"Os clientes não são todos iguais; eles têm desejos e necessidades diferentes e geram retornos diferentes sobre o mesmo investimento para atendê-los. Portanto, é fundamental reconhecer essa diferença para conquistar, manter e fazer crescer continuamente esse relacionamento. Isso é o que permite diferenciar as ofertas e criar peças de comunicação personalizadas" (AURÉLIO LOPES, DIRETOR-PRESIDENTE DA DATAMÍDIA MARKETING DE RELACIONAMENTO APUD COSTA E SILVA, 2002, P. 58). 


\section{Designer: o profissional da revolução}

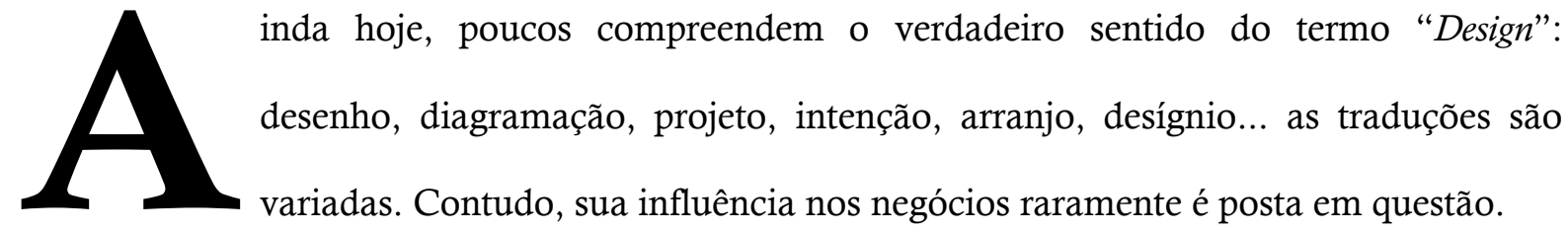

Fazendo parte do mix de produtos de uma empresa (assim como Marketing, Logística, Produção e outros), a área de Design se divide, tradicionalmente, em dois setores distintos: Gráfico e de Produto; esta dissertação versa sobre tecnologia de desenvolvimento de marcas, tópico normalmente relacionado ao Design Gráfico, motivo pelo qual este setor tem um destaque maior na presente explanação.

A profissão de designer é "filha temporã" da Revolução Industrial. Com origem na Inglaterra de 1760, a Revolução Industrial mudou a face do mundo: em sua última fase (a partir de 1900), após o advento da produção em massa, desenvolve-se de maneira importante tal 
profissão, apesar de o verbete "designer" já constar do Oxford English Dictionary desde o séc. XVII (CF. CARDOSO, 2004, P. 15).

Oriundo do trabalho artesão, por força da necessidade de planejar todo o processo produtivo das fábricas que irrompiam por toda Europa durante a Revolução Industrial, o ofício de designer sempre esteve ligado aos setores tecnológicos de ponta, motivo pelo qual, hoje, o computador se incorporou tão intrinsecamente nesta profissão.

Cabe, destacar, contudo, que o computador é apenas uma ferramenta e, como tal, pode ser bem ou mal utilizada, com resultados bons ou danosos. A responsabilidade pela sua aplica-

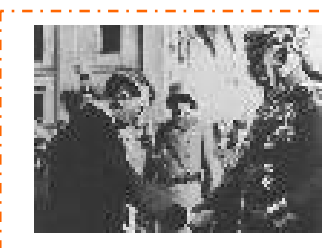

Fig. 18 - Sites racistas: tornam o computador em uma ferramenta demoníaca? ção, portanto, é de quem manipula o micro: a pedofilia ou o terrorismo na Internet não é culpa do computador, mas dos usuários que criam e/ou incentivam tais usos. De maneira similar, é preciso desvincular, pelo menos na análise da qualidade do trabalho gráfico, a marca

do perfil da empresa: uma marca não pode ser danosa ao ambiente, mas podem-se criticar os diretores ou acionistas da empresa. Este distanciamento na análise de tais tópicos, especialmente no presente trabalho, é fundamental para o sucesso do estudo que ora se apresenta: culpe o "artesão", não a "ferramenta". 


\section{Reconhecimento e definição da profissão}

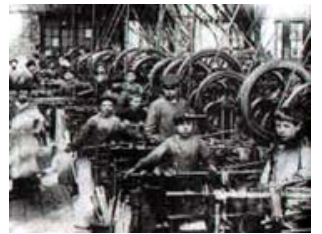

Fig. 20 - Interior de uma fábrica inglesa (séc. XVIII)
Após o "sucesso" da introdução

de máquinas a vapor nas fábricas

inglesas do final do século XVIII, a

produção industrial foi sendo meca-

nizada progressivamente com o passar

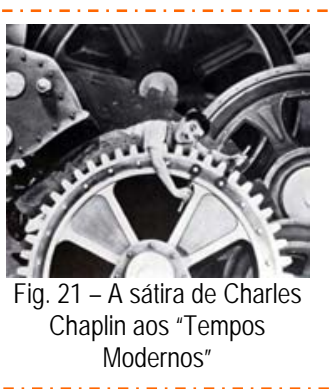

dos anos; em algumas áreas e em certos momentos, a oferta chegou a sobrepujar a procura de produtos. Nestes casos, a racionalização era tamanha que a função do designer era fundamental, pensando a produção como um todo e planejando formas de torná-la mais eficiente.

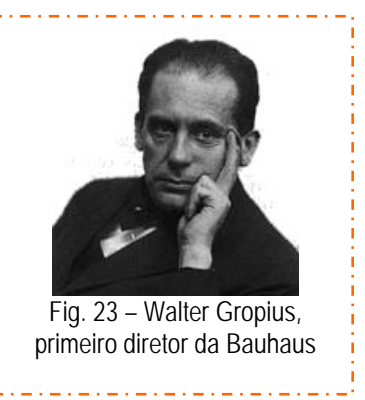

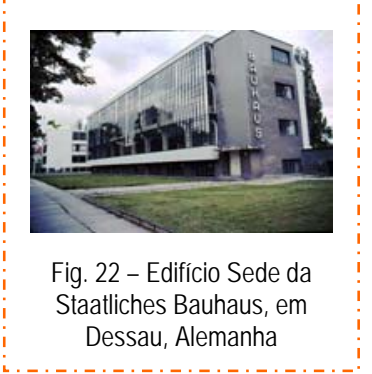

O vanguardismo da Bauhaus (Staatliches Bauhaus, ou Casa de Construção Estatal), a partir de 1919, foi de importância ímpar neste processo, unindo arte e indústria em uma instituição acadêmica e fundamentando muito da prática profissional.

Após o trabalho pioneiro de mestres como Walter Gropius, Ludwig Mies van der Rohe, Wassily Kandinsky e Paul Klee, entre tantos outros, o preceito do Funcionalismo (forma definida pela função) começa a ser cristalizado nas escolas da época, valorizando o conhecimento técnico e tornando o estudo formal do designer cada vez mais importante. Este processo de valorização evoluiu gradativamente até o ponto de, nos últimos 20 anos, a profissão se tornar

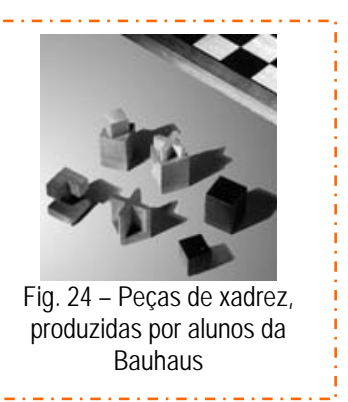


conhecida e corriqueira, mesmo que tal "conhecimento" não se apresente ainda de forma plena e inequívoca.

Cobra, mestre e doutor em administração de empresas, reconhece e destaca a importância do trabalho do designer para os negócios:

"As mudanças no desenho do produto são muitas vezes fatores estimuladores para se prolongar seu ciclo de vida. Tais mudanças tanto podem ocorrer na aparência do produto quanto em suas características, e, portanto, no seu desempenho. A forma, a embalagem, a cor, o estilo, a textura, o desenho, são alguns dos determinantes da aparência.

\section{$[\ldots]$}

Mas a pressão para alterações não depende só do mercado, mas também de inovações tecnológicas que provoquem obsoletismos ou da ação criativa e/ou agressiva da concorrência. Um produto desatualizado em desenho ou desempenho certamente perderá mercado. Mas a atuação da concorrência oferecendo vantagens adicionais poderá alijar um produto do mercado" (COBRA, 1997, P. 209).

Adriana Costa e Silva vê o Design como uma disciplina mais ampla:

"O processo de design demanda conhecimentos que vão desde a concepção de novos produtos, desenvolvimento, produção e marketing até seu descarte. Ao analisar determinado produto, vemos que o design está presente não só na forma de apresentação, como também na embalagem, no manual de uso, nos impressos e materiais promocionais, no merchandising, na marca e no logotipo" (COSTA E SILVA, 2002, p. 100).

Rafael Cardoso destaca a dificuldade de definir o escopo do Design, lembrando que sua origem etimológica (do latim designare) já apresenta uma ambigüidade intrínseca: pode ser traduzida tanto como desenhar ou designar. Sugere, pois, a união das duas idéias, "atribuindo forma material a conceitos intelectuais" (CARDOSO, 2004, P. 14). Identifica o problema do conflito entre a atuação de arquitetos, engenheiros e designers, bem como destes últimos e artesãos ou artistas, sejam plásticos ou gráficos. Rafael destaca, também, que arte, artesanato e design gráfico têm muito em comum (o designer projeta o objeto para ser fabricado por outros, enquanto artista e artesão projetam e produzem o objeto), e que, no atual estágio de maturidade da profissão, alguns designers resgatam a valorização do trabalho manual (IBIDEM, P. 15-16). 


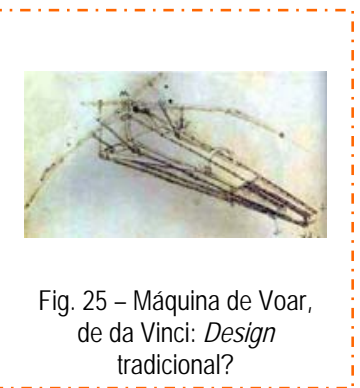

Cardoso também cita o modelo tradicional de Design como sendo "a elaboração de projetos para produção em série de objetos por meios mecânicos" (IBIDEM, P. 15), mas já identifica a dificuldade de aplicá-lo, uma vez que a transição para tal tipo de fabricação não foi simples nem uniforme: já na Antigüidade eram usadas técnicas básicas de produção em série como moldagem de cerâmicas e fundição de metais, com produção razoavelmente padronizada e em larga escala.

O autor ainda relembra os profissionais emergentes de dentro do próprio processo produtivo, sem preparo formal, mas dotados de conhecimento empírico ou habilidade específica, em contraponto com curso superior, que alguns advogam serem os únicos dignos do título de designers, postura que o próprio Rafael desqualifica, acusando de corporativismo sem fundamento, empírico ou histórico.

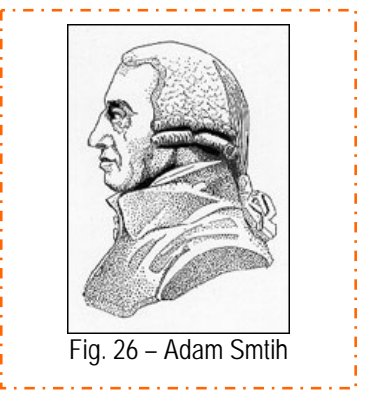

Mais à frente, Cardoso retorna à crescente especialização da produção industrial e redução de empregados com alto grau de capacitação técnica, citando o exemplo de uma fábrica de alfinetes imaginária, criada pelo economista escocês Adam Smith em 1776 para ilustrar as vantagens do trabalho dividido. Neste caso, apenas o designer detinha o controle do processo total, ficando com a tarefa de criar o projeto de produção e, eventualmente, supervisionar os trabalhadores, quando não fosse contratado um gerente para tal ofício (IBIDEM, P. 25-26).

A arquiteta Paula Astiz, mestre em design gráfico pelo Royal College of Art de Londres, valoriza ainda mais a profissão:

"Ser designer, atualmente, não se resume ao exercício de uma atividade técnica, não se restringe em ter competência em uma linguagem visual pré-determinada e aceita, mas sim, e 
sobretudo, em ser capaz de imaginar soluções de forma lógica e criativa, motivadas não por modismos, mas por critérios.

Além disso, mais do que apenas solucionar problemas, a função do designer gráfico hoje é, principalmente, criá-los, no sentido de questionar uma ordem vigente. Acredito no desiǵner gráfico como formador de opinião, com um discurso ativo na produção de novas formas de conhecimento e contribuições significativas à nossa sociedade.

\section{$[\ldots]$}

Em um país como o Brasil, em que as disparidades sociais e econômicas são gritantes, 0 designer deve ter um papel contestador. Nesse sentido, acredito que o designer deva ter o poder de interferir na mensagem transmitida pelo trabalho, ter voz ativa em relação ao seu conteúdo, ao seu significado intrínseco - ou seja, acredito em um trabalho autoral" (ADG BRASIL, 2004, P. 22-23).

A polêmica é grande, mas, na tentativa de concluir uma definição mais abrangente, poderíamos dizer que o designer é o profissional com grande experiência, acadêmica ou empírica, acerca de determinados processos produtivos, que os estuda para reprojetá-los, de forma a otimizá-los pela redução de custos, de prazos e/ou de desperdícios de matéria-prima, visando, ainda, obter o melhor resultado em termos estéticos e de usabilidade, com responsabilidade social e respeito ao meio ambiente. 
O mundo, hoje, é extremamente visual: a quantidade de dados que recebemos via ocular, muitas vezes aceitos com descaso e indiferença, é impressionante. Nas ruas, nas lojas, em casa, estamos expostos a notícias, anúncios, novidades, enfim, informações nas mais diversas formas.

Destacar-se neste intenso fluxo de dados não é tarefa simples, mas é fundamental para determinar o sucesso ou fracasso de uma empresa. E o trabalho de realçar visualmente esta ou

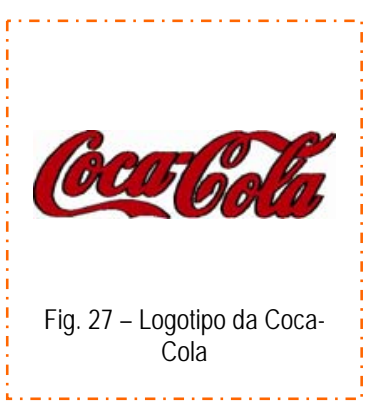
aquela informação é, em grande parte, encargo do designer, e a criação de uma marca bem elaborada é a forma mais eficiente de fazê-lo, bem como o investimento de maior retorno. Neste sentido, Al e Laura Ries lembram que o valor estimado da "marca Coca-Cola" (US\$ 70 bilhões) é quase três vezes superior aos ativos físicos da "empresa Coca-Cola" (US\$24 bilhões) (RIES; RIES, 2006, P. 14).

Pedro Guitton afirma que sempre frisa a importância deste trabalho: "uma marca vai muito além de uma simples sintese gráfica. Por trás dela, existe uma empresa, funcionários e, o mais importante, representa como a empresa se vê e quer ser vista pelo mercado" (GUITTON, 2001, P. 7).

"Design é o processo criativo, inovador e provedor de soluções para problemas de produção, problemas tecnológicos e problemas econômicos, como também para problemas de cunho social, ambiental e cultural" (COSTA E SILVA, 2002, P. 100).

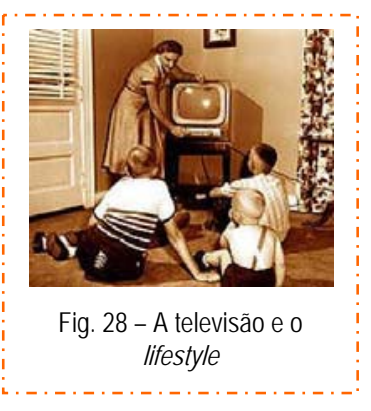

Rafael Cardoso destaca a importância da televisão no desenvolvimento dos campos do Design e do Marketing no mundo pós-moderno, especialmente pela cristalização de um conceito fundamental para estas áreas: o lifestyle (estilo de vida) (CARDOSO, 2004, P. 181). A idéia de que uma mercadoria era mais que um simples 
produto, inserida em uma rede de associações, valores, imagens e emoções, daria um impulso importante para o trabalho do profissional de design.

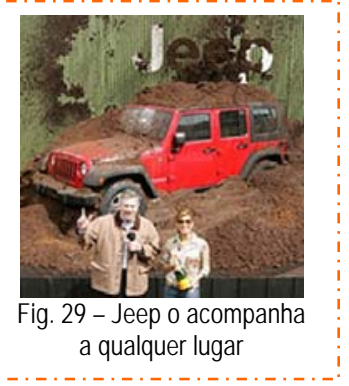

Você não comprava mais um Jeep, mas a liberdade de ir a qualquer lugar; não consumia um Big Mac, mas a praticidade de almoçar com amigos em um ambiente alegre; nem mais adquiria um Rolex, mas a sofisticação de quem não precisa se preocupar com o tempo. Neste cenário, a função do designer não se restringia mais à racionalização de processos e valorização funcional e estética: era necessário antever o modo de venda, a distribuição, a manutenção e, mesmo, a devolução e a substituição do produto.

Agora, o Design, como o Marketing e em estreita relação com este, não seria mais dirigido pelo produto, mas pelo atendimento de desejos e anseios do cliente, o consumer-led design (design conduzido pelo consumidor) (CARDOSO, 2004, P. 185): o Marketing planejaria a maneira de responder às necessidades do cliente, enquanto o Design proveria a forma e o visual desejado por este.

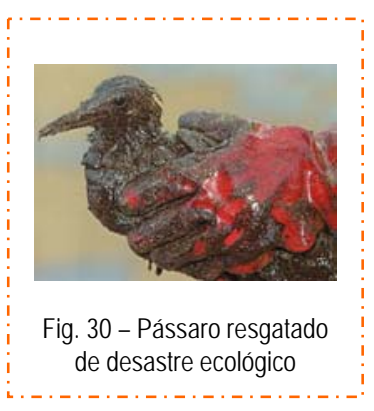

Paralelos a este processo, já no fim dos anos 80 , surgiram os primeiros problemas ecológicos de grandes proporções, e o mundo, de modo incipiente, mas progressiva e indelevelmente, se voltou para produtos que respeitavam o meio ambiente, processo hoje chamado de consumismo verde (CARDOSO, 2004, P. 217).

Termos como "reciclagem", "reuso", "baixo consumo de energia" e "redução de desperdício" foram se incorporando paulatinamente ao vocabulário diário dos consumidores, e, uma vez mais, os designers foram chamados a colaborar. 
Por fim, o fenômeno, ainda recente, da globalização, com seu slogan "think globally, act locally" (pense globalmente, aja localmente) (CARDOSO, 2004, P. 220), também colaborou para a valorização do designer. Afinal, tal profissional, que estuda e pode controlar a produção de um objeto, tem a capacidade de adequar determinado processo para se ajustar a qualquer orientação, seja de mercado, ambiental ou outra aspiração que "Sua Majestade, o consumidor," manifeste na hora da compra. Este é, em última instância, o motivo pelo qual hoje os cursos de Design, no Brasil e no mundo, apresentam uma procura tão grande. 
Antonio Celso Collaro, em seu livro "Projeto Gráfico", ensina como era feito o cálculo de consumo de material para a impressão de um livro na "era pré-informática": número de toques médios por linha de texto multiplicado pela largura média do caractere utilizado, multiplicado pelo número médio de linhas por página, este resultado dividindo o número de caracteres totais do texto, somado ao mesmo processo em relação aos títulos, divisórias, tabelas, fotos... Com muita paciência e uma boa calculadora, chegaríamos, com certa precisão, ao consumo, quase exato, de papel de uma publicação! (COLLARO, 2000, P. 61-68)

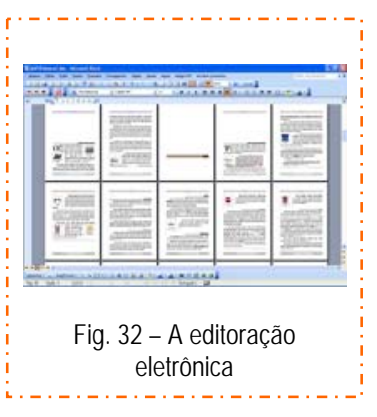

A utilização dos computadores no processo (entre outros) de diagramação editorial eliminou toda esta complexa operação estatística, controlando, de forma muito mais precisa, o investimento em material para produção de uma publicação.

Do escritor/criador até a gráfica, o processo de elaboração e execução de qualquer material impresso é quase todo feito em meio eletrônico. E este é apenas um aspecto da produção de um designer: o desenvolvimento de produtos também é muito influenciado pela tecnologia disponível a cada dia.

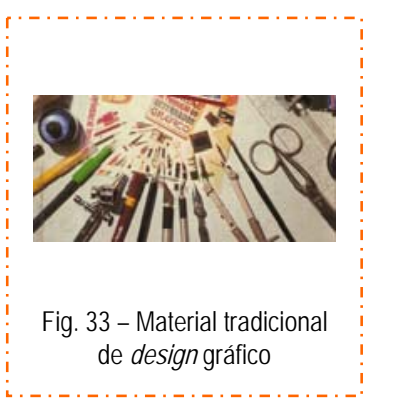

Rogério Batagliesi destaca também a praticidade do uso do computador. Antes dele, era comum o uso de talco para manipulação de canetas gráficas (bem como a "chupadinha" necessária para desentupir os modelos mais finos), benzina, "bigode", giletes, folhas de Letraset, régua paralela, curva francesa, 
colas diversas... A lista é longa. O computador substitui tal rol de materiais e mais: "não precisamos dar uma 'chupadinha' no mouse para ele desentupir, nem passar talco no teclado para não deixar marcas de gordura na impressão" (ADG BRASIL, 2004, P. 153).

Batagliesi também reconhece outra grande vantagem do processo computadorizado: ele economiza tempo e dinheiro; tal redução no tempo de produção de peças de design, sugere o autor, deve ser aproveitado nas fases de concepção, reflexão e planejamento, trazendo maior qualidade para o trabalho final. "É um ótimo motivo para usarmos computadores" (ADG BRASIL, 2004, P. 155).

Além da velocidade de execução, Rogério lembra dois outros aspectos influenciados pelo uso do computador como ferramenta, e que levaram a uma mudança do perfil de atuação do designer gráfico: o aumento da qualidade (os recursos digitais propiciaram uma significativa melhora no processo de produção gráfica) e da responsabilidade profissional (o designer se apresenta intrinsecamente incorporado no processo produtivo e suas eventuais falhas refletem diretamente nos prazos e na qualidade do produto final). "Poucas profissões sofreram um impacto tão benéfico da informática quanto a do designer gráfico, como também poucas receberam, em conseqüência, um aumento tão grande na sua carga de responsabilidades" (ADG BRASIL, 2004, P. 157).

Paula Astiz reforça as facilidades promovidas pela inclusão de recursos informatizados no trabalho do designer.

"As recentes possibilidades da tecnologia digital permitiram que o designer se aproximasse muito mais de todas as etapas do trabalho, desde a criação até a finalização de arquivos para a gravação de chapas, sem a necessidade de gerar fotolitos, por exemplo" (ADG BRASIL, 2004, P. 23). 
Paulo Gomes de Oliveira Filho concorda, mas levanta importante aspecto em sentido contrário:

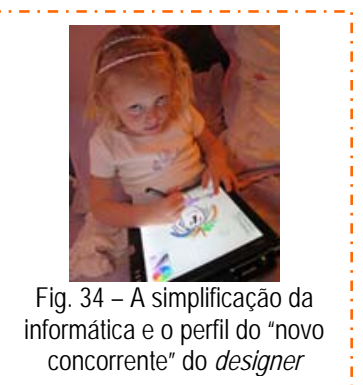

Independentemente de tais problemas, a informática é, efetivamente, uma das ferramentas mais versáteis e de ampla aplicação que surgiram no último século, tendo sido incorporada no trabalho diário de grande parte dos designers modernos. Sejam estes voltados para a área gráfica, de produto ou qualquer nova subdivisão que possa surgir: sem computador, perdese em qualidade, em prazo, em agilidade... enfim, é quase impossível encontrar um conceituado escritório de Design sem diversos microcomputadores espalhados por suas dependências.

No entanto, Adriana Costa e Silva lembra que a popularização do computador como ferramenta de design prejudicou, em parte, a produção dos profissionais brasileiro, uma vez que levou a uma dominância dos "códigos internacionais" sobre os locais, justamente em um momento que a produção gráfica nacional amadurecia e se destacava como forma de expressão própria, nas décadas de 80 e 90 (COSTA E SILVA, 2002, P. 100).

Rafael Cardoso, por sua vez, destaca o lado positivo da informática, lembrando que tanto interatividade (a maneira de interagir, os caminhos da informação) como interação (os elementos utilizados para interagir: botões, vídeos, músicas...), tão comuns no "mundo virtual", precisam ser projetadas e configuradas, apresentando-se, aí, mais uma oportunidade para o trabalho do designer (CARDOSO, 2004, P. 210). E o trabalho com fragmentação visual, outra característica ligada ao 
espaço virtual, não é novidade para o profissional de design gráfico: processos gráficos como litografia, rotogravura e fotolito, entre outros, já utilizavam tal técnica, muito antes do surgimento dos modernos computadores.

O desenvolvimento de sistemas operacionais e programas gráficos de fácil manuseio surge como uma "faca de dois gumes": de um lado, torna simples e barato manipular fontes, entrelinhas, espacejamento e uma série de propriedades e características que antes eram exclusividade do tipógrafo profissional; por outro, o trabalho fica restrito àquilo que o aplicativo permite, uma vez que seu uso é feito por menus de comando, que restringe, ao menos parcialmente, a criatividade do artista.

Cardoso cita, também, que algumas pesquisas, ainda que de forma incipiente, sugerem que o uso do computador pode levar a uma homogeneidade maior de resultados gráficos obtidos:

"Não seria justo, evidentemente, culpar a ferramenta pela falta de criatividade do projetista; porém, a difusão quase universal e às vezes exclusiva de alguns poucos programas, plataformas e provedores gera uma situação em que todo o cuidado é pouco para evitar um novo dogmatismo nas formas de proceder. 0 velho senso de mistério e de magia diante da folha em branco, experiência fundadora nos relatos de tantos mestres do passado, definitivamente não parece se traduzir com a mesma intensidade para o espaço da tela apinhada de ícones e barras de ferramentas" (CARDOso, 2004, P. 213).

Batagliesi acrescenta outro problema relacionado ao uso do computador como ferramenta gráfica:

"Infelizmente, designn gráfico [...] é uma matéria sobra a qual o leigo se julga tão qualificado quanto o profissional, e, portanto, capaz de julgar, perturbar e destruir um trabalho sério - e também de interferir no seu andamento.

Muita gente imagina que o simples fato de ter à frente um computador poderoso e um programa gráfico o torna um designer gráfico, transformando, assim, nossa função em algo banal, que pode ser executada por qualquer um. Por saberem operar um PowerPoint e/ou CorelDraw, essas pessoas começam a acreditar que, com seu bom gosto, repertório e inteligência, são capazes de elaborar peças gráficas de igual ou superior valor àquelas produzidas pelos designers gráficos. 0 resultado, em geral, é aquele desastre que estamos acostumados a ver por aí" (ADG BRASIL, 2004, P. 154). 
O autor ainda levanta algumas armadilhas a que o designer se expõe, quando dependente do equipamento:

"Cinema, televisão e computador têm o poder quase subliminar de provocar um efeito hipnótico sob o qual nossa visão, sentidos e sentimentos interagem, em experiências sensoriais individuais. [...]

As possibilidades oferecidas são tantas, tão simples e inebriantes, que a criatura se apodera do criador, tornando-o insensível e alheio ao mundo real. É comum observar o computador transformar-se no simulacro da visão do designer. [...]

Além da sedução fácil, existe outro malefício, que costumo chamar de 'Síndrome de Uainóti'. A facilidade de alterações de imagens, cores e afins é inesgotável e, se o interlocutor perceber alguma insegurança de nossa parte, pedirá um número infindável de testes.

'Tenta agora o roxo com o laranja'. [...]

[...] É bom lembrar que ainda não está à venda 0 computador a vapor. 0 que nos torna dependentes da energia elétrica. É claro que existem os notebooks a bateria, no-breaks e geradores. Mas não é sempre que podemos contar com tais facilidades" (ADG BRASIL, 2004, P. 155-156).

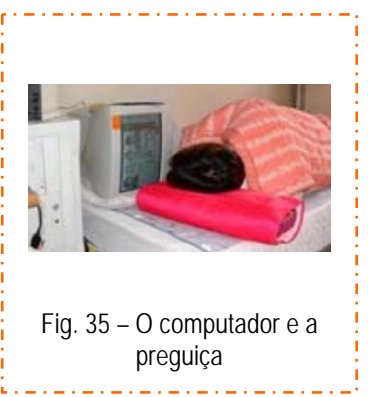

Bruno Munari afirma que "a preguiça é o motor do progresso" (MUNARI, 2001, P. 53): queremos sempre o máximo resultado, com o mínimo esforço. Neste sentido, o computador se apresenta como um grande paradoxo: consegue atingir o resultado máximo, mas a necessidade do esforço mínimo é questionável. Como qualquer outra ferramenta, é necessário dominar seu manuseio, para poder extrair seu melhor resultado. E o tempo para dominar tal ferramenta pode ser bem maior que "mínimo".

Infelizmente, muitas pessoas pensam que, para dar a aparência profissional a um trabalho, basta utilizar o computador que o resultado será melhor, independente de se estudar devidamente os princípios básicos do design, como semelhança, contraste, uso de cores, pregnância de formas, dentre outros conceitos clássicos. E tais conceitos independem e precedem o design computadorizado. E, como bem destaca Rogério Batagliesi:

"[...] Acreditamos que 0 tempo e a performance do trabalho braçal e mecânico poderá melhorar com a evolução das máquinas. Ainda assim, o pensamento, a elaboração, a interação e a 
integração entre problemas e soluções que o design gráfico enfrenta e articula permanecerão os mesmos. Pelo menos até agora.

E para todo o sempre, espero!" (ADG BRASIL, 2004, P. 158)

Não existe design moderno sem informática: este conhecimento já um importante diferencial para o designer de hoje, e a tendência é que se torne mais indispensável com o passar dos anos. E, para se conseguir tal habilidade, faz-se necessário entender suas características técnicas, suas possibilidades e suas restrições. Perceber sua influência em determinadas áreas, como o desenvolvimento de marcas, é só um começo, só a "ponta do iceberg"... 


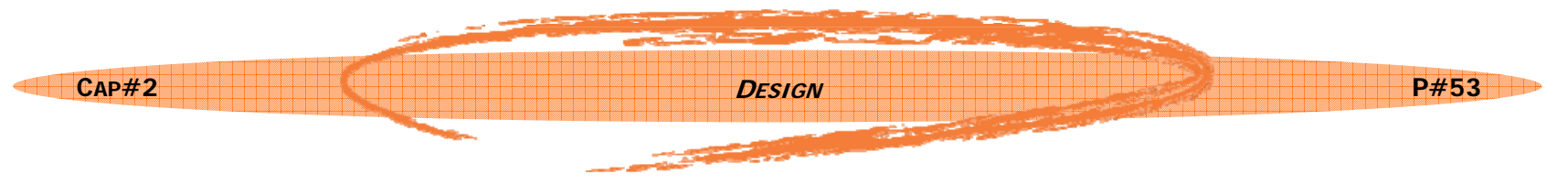

Design manual

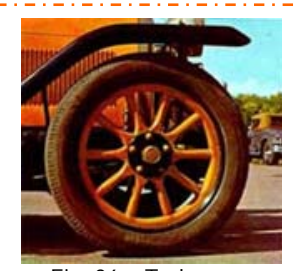

Fig. 36 - Toda nova tecnologia tem início em outra precedente
Antes do pneu, veio a roda; antes do design computadorizado, o manual. A profissão de designer antecede o surgimento dos computadores modernos; por outro lado, estes podem, quando corretamente utilizados, facilitar os trabalhos destes profissionais, seja na área gráfica ou de produto.

Rogério Batagliesi afirma que "usar o computador não o transforma em designer gráfico". E continua: "para ser designer gráfico, você não precisa de um computador":

"Aparentemente, e na prática, é muito bom um designer gráfico utilizar um computador. Mas não é imprescindível. Eu diria, até, que, em certos momentos, seria dispensável. 0 computador é imprescindivel para um arte-finalizador, que dá o tratamento e acabamento tanto nas apresentações como nas saídas de impressão. É muito comum ver excelentes profissionais trabalhando à mão. [...]

[...] [0 designer australiano] Ken Cato, que possuía escritórios em inúmeras capitais do globo, declarou que sempre começava um trabalho desenhando à mão, pelo prazer que o contato do lápis com o papel proporcionava, ajudando-o também a pensar. [...]

Preciso ainda repetir que o verdadeiro designer gráfico utiliza o computador como um 'meio' para concretizar um projeto, mas que este nasce em nossos corações e mentes?" (ADG BRASIL, 2004, P. 154-155).

Paula Astiz concorda com os perigos da "computação pela computação":

"Se há vantagens nessa aproximação [entre o designer e as etapas de seu trabalho] - pois 0 designer domina mais integralmente 0 projeto, permitindo-se tomar decisões no início, já visualizando a solução de problemas técnicos que surgirão ao final do processo -, por outro lado, um excessivo preciosismo técnico pode distraí-lo de questões globais mais relevantes. Não é o manejo de programas gráficos mais atualizados que irá conferir qualidade a um trabalho, mas sim as idéias do designer, que constituem o cerne do projeto e em decorrência das quais se desenrola esse processo.

É importante mencionar que, além de aproximar o designer do processo gráfico como um todo, essas mesmas inovações tecnológicas, e a facilidade de acesso a elas, acabaram atraindo indivíduos sem formação adequada para a atividade. Estes presumem que, por dominarem diversos programas e plataformas, entendem também da tradição, dos conceitos e dos cânones que constituem 0 design. 
Acredito num retorno à ênfase dada ao conteúdo, que vai superar as preocupações formais relativas ao desiǵn gráfico. Após uma década de intenso interesse e desenvolvimento do desiǵn de tipos digitais, por exemplo, em que a experimentação foi praticamente esgotada, vemos renascer 0 interesse pela imagem e pela construção de sentido.

Uma vez que o acesso ás novas tecnologias é cada vez mais amplo, e, ao mesmo tempo, as relações entre publicidade, design gráfico, comércio e cultura estão mudando rapidamente, há pouca noção do papel, da concepção de valores e do sentido de responsabilidade da profissão. Resta ao designer definir uma postura clara e mais responsável quanto aos critérios envolvidos na mensagem a ser comunicada" (ADG BRASIL, 2004, P. 23-24).

Ana Luiza Escorel (ESCOREL, 2004, P. 45) reforça tais idéias: "[...] para projetar com competência, o designer precisa, antes de mais nada, processar os dados de sua própria identidade, esquivando-se dos atalhos conhecidos, trilhados por ele mesmo ou pelos colegas de profissão". E também: "A elaboração de um programa de identidade visual para empresas pressupõe a compreensão de uma dada organização em seus aspectos estruturais, em seu desempenho, em seus objetivos estratégicos". Nenhum destes itens depende do computador.

Marcello Montore reforça a relação de independência entre design e informática:

"Os três ingredientes básicos para um bom designer resumem-se em talento, criatividade e repertório. 0 talento, em geral, é nato. A criatividade pode ser estimulada e desenvolvida. 0 repertório, que se reflete na cultura do designer, vai sendo adquirido ao longo da vida e, sobretudo, através da leitura. Por isso, não lhe dar a devida atenção significa privar-se de parte do desenvolvimento pessoal necessário para produzir um bom profissional" (ADG BRASIL, 2004, P. 199).

Cecília Consolo comenta sobre "Ponto e linha sobre o plano", de Wassily Kandisnky, e dá um depoimento interessante sobre design, que em nada se relaciona, diretamente, com a computação gráfica: "Este livro mudou minha vida quando eu ainda era estudante de graduação. Fez com que eu visse que desenho é uma forma de pensamento e um processo mental de apreender o mundo fisico e imaginário" (ADG BRASIL, 2004, P. 206).

O ensino também é uma preocupação de Edna e Guilherme Cunha Lima:

"Há cerca de quinze anos, a substituição das pranchetas pelos computadores e do conhecimento tradicional das artes gráficas pelos programas eletrônicos tomou nossa profissão de surpresa. Não que os designers estivessem desatualizados, ou que as escolas não previssem a importância crescente dessas mudanças. 0 que surpreendeu foi a rapidez com que leigos se 
colocaram como experts, em que donos de microcomputadores passaram a se considerar aptos para concorrer no mercado com profissionais de formação universitária.

Depois de tentar durante décadas explicar à sociedade o que é o design, tarefa que as associações sempre levaram a sério, passou-se agora para outra perspectiva, ou seja, a de mostrar níveis de competência profissional. Não basta saber operar bons programas gráficos, é necessário algo mais. As discussões dentro das universidades procuraram esclarecer as diferenças que se delineavam para poder atender às demandas da profissão. Em que consistiriam essas novidades? 0 mercado logo percebeu que os softwares evoluíam com uma rapidez tal que era inútil focar neles a atenção das escolas" (ADG BRASIL, 2004, P. 165).

Ana Luiza termina citando o que considera serem "as duas condições essenciais à dinâmica da expressão, em design gráfico: a disciplina, que conduz à nitidez precisa do traçado, com a audácia, que encaminha para os terrenos incertos da invenção" (ESCOREL, 2004, P. 45). Mais uma vez, tais condições primam pelo procedimento, não pela ferramenta de trabalho utilizada.

Sem o devido planejamento prévio, este sendo o berço da profissão, é quase impossível atingir um bom resultado. Tal planejamento prescinde de qualquer forma automatizada; ao contrário, esta fase, costumeiramente, é melhor desenvolvida quando parte de "uma folha em branco", "suporte básico que aceita tudo", sem direcionar para esta ou aquela solução, como ocorre, freqüentemente, com o planejamento inicial via computador. 


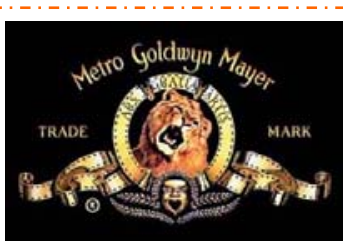

Fig. 37 - Logomarca da Metro-Goldwyn-Meyer
Por mais paradoxal que possa parecer, os princípios do Design ficaram por último. Infelizmente, esta é uma constante na maioria dos trabalhos gráficos da atualidade, que se concentram muito na apresentação ars gratia artis (a arte pela arte - slogan da MetroGoldwyn-Meyer) e ignoram o embasamento desta. Coincidente-

mente, tais trabalhos tendem a ser, justamente, aqueles que mais problemas apresentam na correta comunicação visual da mensagem que se propõem a transmitir.

Neste sentido, Ana Luiza Escorel destaca a importância de um bom método de trabalho:

"A Metodologia de trabalho em design pressupõe uma maneira própria de abordar e resolver problemas. 0 designer pode usá-la para atuar também como planejador e como assessor, funções alheias à atividade de projeto. É um engano, portanto, afirmar que metodologia e projeto são uma coisa só" (ESCOREL, 2004, P. 101).

No que se refere a qual método e, especialmente, quais princípios utilizar, novamente, a variação é diretamente proporcional ao número de autores pesquisados. Cada um tem sua teoria ou, pelo menos, sua adaptação à teoria de outrem.

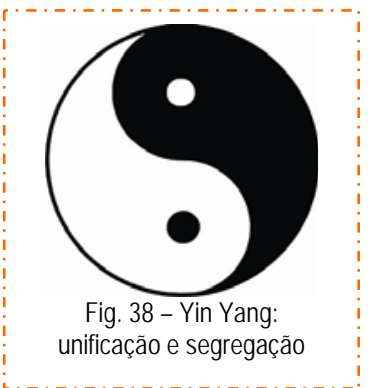

Gregory Thomas (THOMAS, 2003, P. 18) sugere dez critérios para desenvolver logos, símbolos

Pedro Guitton (GUITTON, 2002, P. 18-21) usa a teoria da Gestalt, de Christian von Ehrenfels, com os conceitos de unificação e segregação, proximidade e semelhança, fechamento, boa continuação e pregnância de forma.

e ícones de sucesso: visibilidade, aplicabilidade, distinção de concorrentes, simpli- 


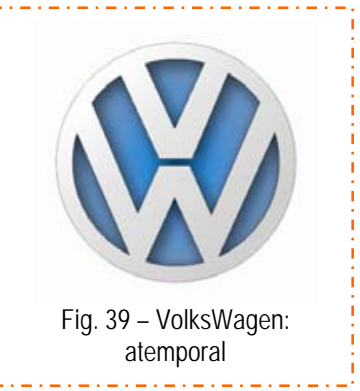

cidade/universalidade, retenção, flexibilidade cromática, identificação do produto/empresa, independência de referências temporais (timelessness), modularidade e imparcialidade (equity).

A prática designer Robin Williams (WILLIAMS, 1995, P. 14 ET SEQ.), homônima do ator de Hollywood, sugere quatro precipícios básicos: proximidade, alinhamento, repetição e contraste.

Arnheim (ARNHEIM, 2005), como Guitton, também se refere aos estudos da Gestalt, destacando e descrevendo, pormenorizadamente, conceitos como equilíbrio, configuração, forma, desenvolvimento, espaço, luz, cor, movimento, dinâmica e expressão.

Wucius Wong (WONG, 2001, P. 41-44), discípulo de Rudolf Arnheim, divide a análise da linguagem visual em elementos conceituais (ponto, linha, plano e volume), visuais (formato, cor, tamanho e textura), relacionais (direção, posição, espaço e gravidade) e práticos (representação, significado e função).

David Dabner (DABNER, 2003, P. 10-85) lista como princípios básicos de Design: formas básicas, equilíbrio e harmonia, tipos de letra, exposição, cor, análise da informação, fotografia e relação texto/imagem.

Conforme ilustrado acima, no que se refere a princípios, assim como métodos de trabalho, temos inúmeras possibilidades. Cada autor que se busque trará uma sugestão diferente. E, como quase tudo que se estude na área da percepção visual, não existem certos ou errados: é preciso pesquisar qual opção melhor se adapta para cada necessidade específica de design. O que funciona para alguns casos, pode se apresentar inócuo, incorreto ou desaconselhável em outros. 


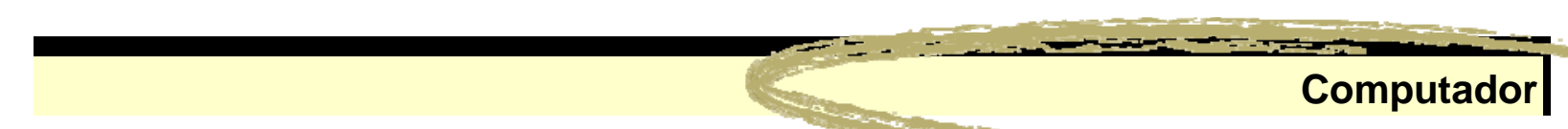



computador, ou, mais precisamente, o microcomputador, é o produto que melhor define nosso modo de vida atual, inseparável companheiro do atual estágio de nossa "sociedade tecnotrônica" (BRZEZINSKI, Z. APUD DE MASI, 1999, P. 31).

É impossível imaginar a vida, especialmente nas grandes cidades, sem facilidades informatizadas como caixas eletrônicos, cartões de débito, pesquisas na Internet, comunicação via e-mail. Nem mesmo a fotografia, a música, a telefonia e a televisão modernas escapam ao seu alcance. A idade tampouco é um empecilho a sua utilização: da "primeira" à "terceira" idade, todos são influenciados (quando não fascinados) por esta ferramenta de versatilidade ímpar.

Este produto, como hoje é conhecido, exigiu muita pesquisa e desenvolvimento para chegar à casa ou ao escritório do consumidor com um desempenho razoável e um preço viável. 


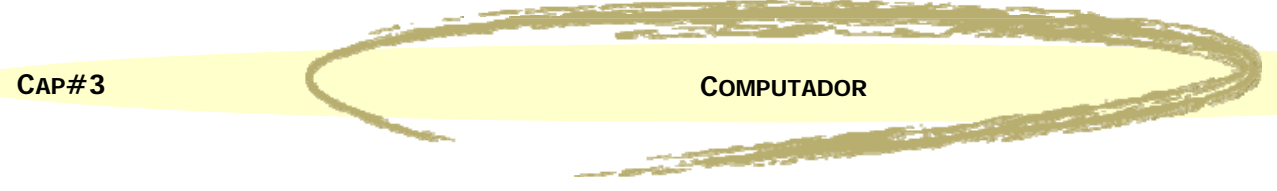

P\#60

Era uma vez...

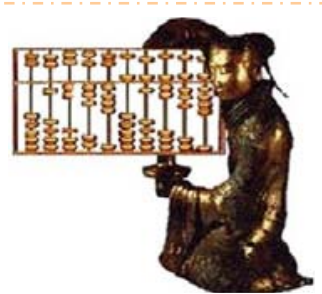

Fig. 40 - Ábaco

A história dos computadores começa bem antes do século XX: já na Antigüidade (por volta de $2.000 \mathrm{aC}$, talvez ainda há mais tempo...), quando o homem começou a utilizar instrumentos de cálculo como o ábaco; estas pequeninas "máquinas de calcular" foram as precursoras do computador moderno

(CF. HTTP://WWW.BABOO.COM.BR/ABSOLUTENM/TEMPLATES/CONTENT.ASP?ARTICLEID=3591\&ZONEID=24, ACESSADO EM 28 DE MAIO DE 2006).

Desde então, muito avanços foram feitos, paulatinamente, nas áreas de cálculo e organização de informações; porém, começa-se a ter notícias importantes na era moderna, quando muitos cientistas chegaram, em diversos países e quase ao mesmo tempo, a descobertas semelhantes, que contribuíram para a criação do computador.

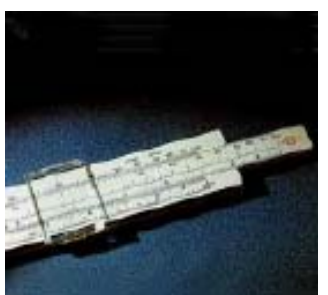

Fig. 41 - Régua de cálculo
A partir do século XVII, os inventos se "multiplicaram": a régua de cálculo (c. 1622) do matemático inglês William Oughtred e a Máquina Pascalina (1642) do matemático francês Blaise

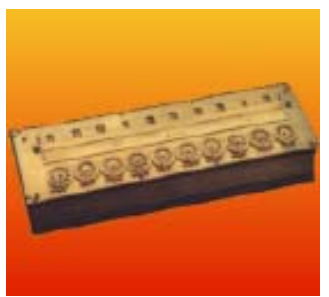

Fig. 42 - Máquina Pascalina

Pascal, ambas com soma, subtração e multiplicação.

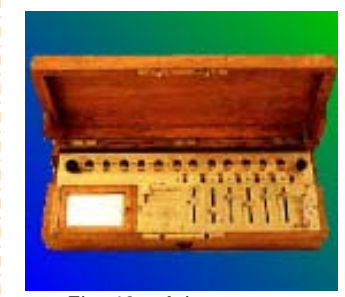

Fig. 43 - Aritmômetro
Após dois séculos, outra série de inventos impulsionou o desenvolvimento do computador: o Aritmômetro
(FREEDMAN, 1995, P. XXIV) do

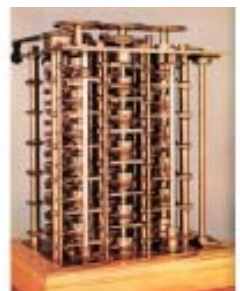

Fig. 44 - Máquina Diferencial 


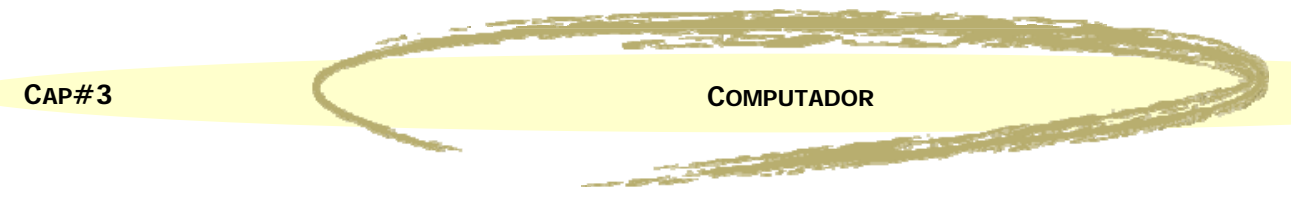

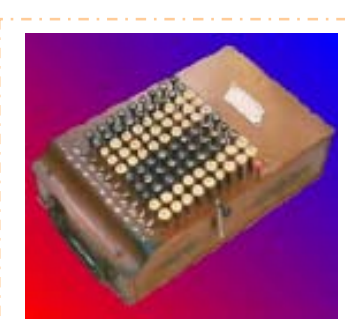

Fig. 45 - Computômetro

comandada por teclas.

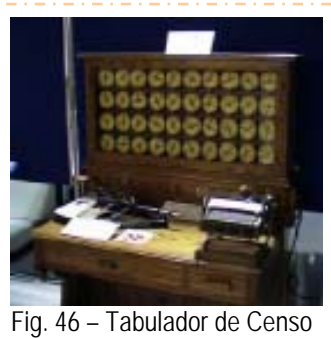

industrial francês Charles Xavier Thomas de Colmar, a Máquina Diferencial (1821) do matemático inglês Charles Babbage e o Computômetro, criado em 1886 pelo americano Dorr Eugene Felt e aperfeiçoado, quatro anos depois, pelo engenheiro sueco Willgodt Theophil Odhner, tornando-se a primeira calculadora comercial Paralelamente a estes desenvolvimentos na Europa, o engenheiro de minas americano Hermann Hollerith desenvolveu o Tabulador de Censo (1890), inspirado no tear programável do francês Joseph Marie Jacquard, que usava cartões perfurados para comandar seqüências de operações pré-determinadas.

Em 1880, o congresso americano havia aprovado a lei que regulamentava o período de recenseamento para 10 anos. O Tabulador de Hollerith analisava e comparava grandes quantidades de informações, tarefa hoje conhecida como "processamento de dados", e reduziu o tempo de divulgação do censo americano, de 7,5 anos (censo de 1880) para 2,5 anos (1890) (IBIDEM, P. XXIV).

Em 1896, Hollerith fundou a Tabulating Machine Company, para ampliar o uso de seu invento além do censo: verificação de estatísticas de fretes de ferrovias, execução de cálculo de custo de produção de uma fábrica de ferramentas e análise de folhas de pagamento e inventários da administração de lojas de departamentos (CF. HTTP://TURNBULL.MCS.ST-AND.AC.UK/HISTORY/BIOGRAPHIES/HOLLERITH.HTML). 


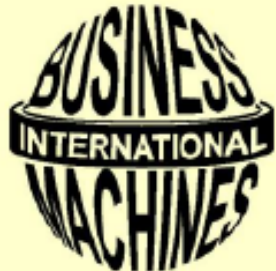

Fig. 47 - Marca original (1924)

Em 1924, Hermann mudou a razão social de sua companhia para International Business Machines - IBM, e continuou desenvolvendo suas idéias na área de cálculos e estatísticas

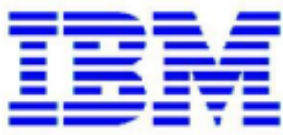

Fig. 48 - Logotipo atual (1972)

"automatizadas"; assim, a IBM prosperou e, mais tarde, fez parte do grupo que desenvolveu o primeiro computador.

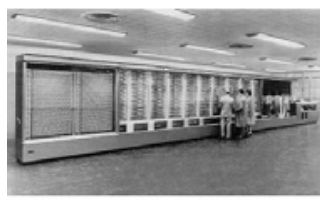

Fig. 49 - A "escala humana" do Mark 1

Entre 1943 e 44, a IBM associou-se a uma equipe de cientistas da Marinha Americana e da Universidade de Harvard, sob a coordenação do físico Dr. Howard Aiken, para criar o Mark 1, que realizava operações aritméticas complexas e tinha, para a época, uma velocidade fantástica: conseguia multiplicar dois números, com

10 algarismos cada, em 3 segundos.

O Mark 1 pesava 5 toneladas, com 120 metros cúbicos, ocupando 30 metros quadrados, sendo usado para fins militares, e executando cálculos de balística.

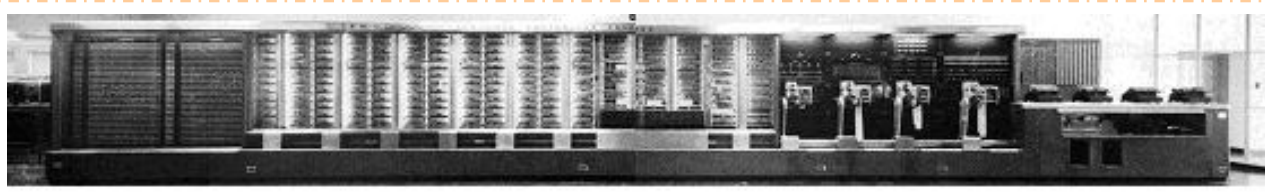

Fig. 50 - Mark 1

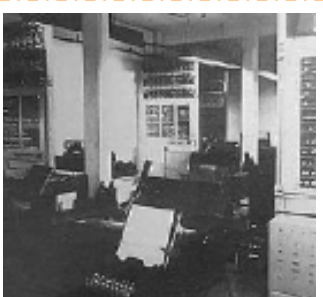

Fig. 51 - Colossus 1

$\mathrm{Na}$ Inglaterra, também em 43, Alan Turing concebeu e construiu o Colossus 1, para decifrar mensagens alemãs codificadas durante o final da guerra. 


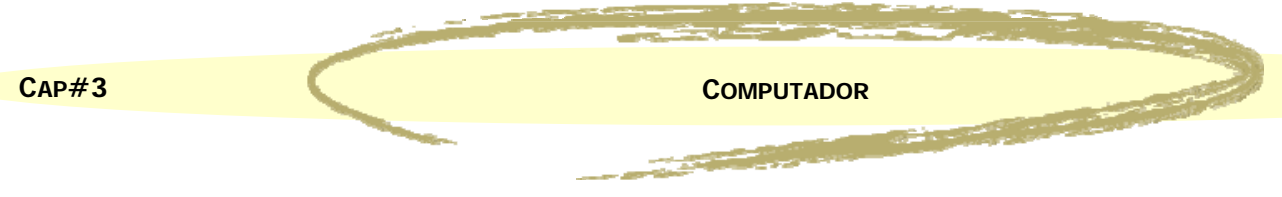

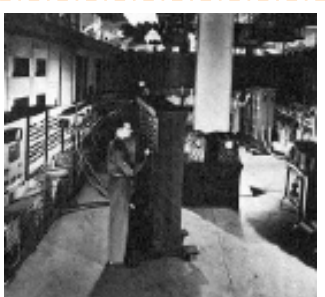

Fig. 52 - ENIAC

Com equipe chefiada por John Presper Eckert e John Mauchly, o exército americano envolveu-se no projeto do ENIAC Electronic Numerical Integrator Analyser and Calculator, a calculadora e analisador numérico integrado eletrônico, concluído em 46, após o término da guerra, e então usado em aplicações científicas.

\section{As quatro gerações de computadores}

"Desde os primórdios, até hoje em dia [...]"*, listam-se quatro gerações de computadores, com estas categorias baseadas na tecnologia empregada em seus processadores: válvulas, transistores, chips e microprocessadores.

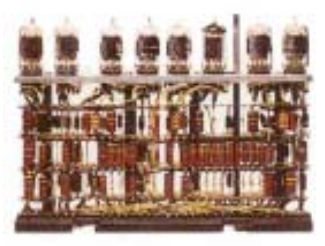

Fig. 53 - Computador a válvula

Considera-se da primeira geração, o período de 1946 a 56, os computadores que utilizavam válvulas eletrônicas (FREEDMAN, 1995, P. XXVIII) como processadores. Essas válvulas eram grandes e lentas, aqueciam em demasia e queimavam com facilidade. Apesar de comercializados, eram construídos para uso científico e desen-

volvimento de pesquisas em computação: devido ao seu alto preço (vários milhões de dólares), eram adquiridos apenas por órgãos governamentais e grandes corporações. Mesmo com custo quase proibitivo, tinham uma capacidade minúscula se comparados aos atuais - de 4 a $8 \mathrm{kB}$.

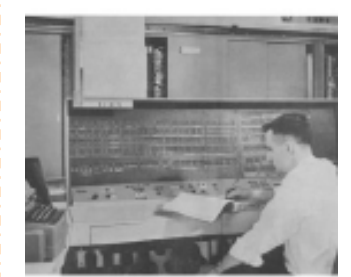

Fig. 54 - Univac modelo 1105

Em 1951, lançou-se o primeiro modelo comercial, o Univac UNIVersal Automatic Computer, ou computador automático universal - produzido pelos projetistas do ENIAC. O primeiro computador instalado no Brasil foi um Univac 1105, em 61, do

*Trecho de Homem Primata - Titãs. 


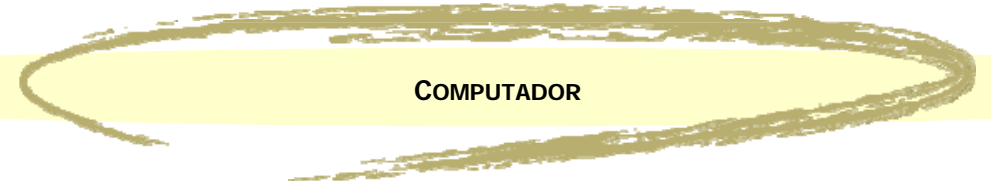

Instituto Brasileiro de Geografia e Estatística - IBGE (IBIDEM, P. XXVIII-XXIX).

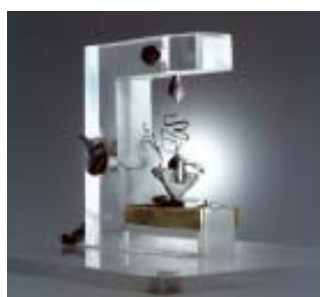

Fig. 55 - Primeiro transistor

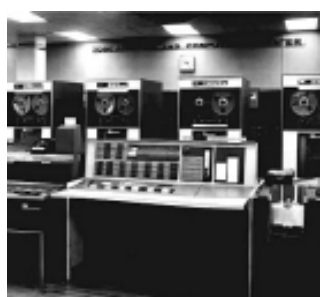

Fig. 57 - IBM 7094
Entre 1957 e 1963, surgiram os modelos de segunda geração, menores, mais potentes, confiáveis, baratos e duráveis, com transistores (IBIDEM, P. XXVIII) como processadores.

Seus mais significativos modelos foram o IBM 7094 e o CDC 6600. Porém, válvulas e transistores realizavam um processamento por vez, fato que limitava sua velocidade.

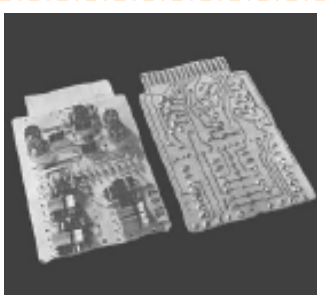

Fig. 56 - Transistor "moderno"

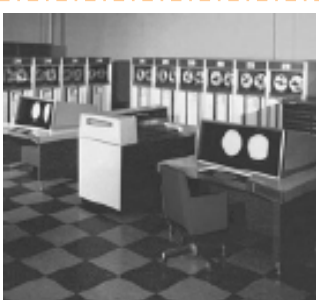

Fig. 58- CDC 6600

Os computadores de segunda geração eram bem menores que seus antecessores; mas, apesar de mais baratos, ainda eram acessíveis somente a grandes empresas. Nesta fase, surgem as linguagens de programação, que democratizaram e ampliaram o uso dos computadores para além das aplicações de caráter científico.

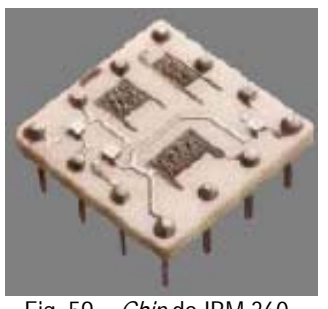

Fig. 59 - Chip do IBM 360

De 1964 a 1971, surgiu a terceira geração. No início dos anos 60, apareceram os chips (pastilhas) (IBIDEM, P. XXIX) de CI - circuitos integrados, cápsulas de silício, um dos mais abundantes elementos na crosta terrestre. O chip era uma pequena pastilha, capaz de conter dezenas, centenas ou mesmo milhares de transistores. Os computadores reduziram expressivamente em tamanho e, com a produção de chips em larga escala, contribuíram decisivamente para baixar o custo e ampliar o uso dos mesmos. 


\section{intel.}

Fig. 60 - Logotipo Intel

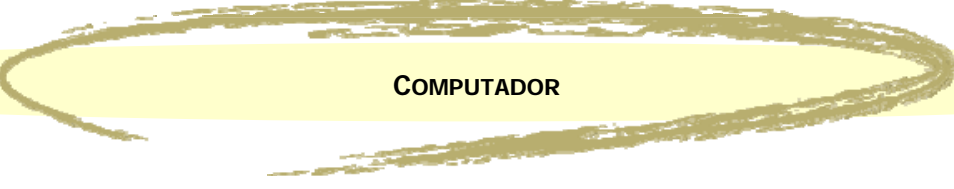

Em 1969, nasce a Intel (BIDEM,

P. XXXIII), formada por funcionários da

Fairchild Semiconductors, que criara os circuitos integrados, dez anos antes.

Neste ano, a empresa começa a desen-

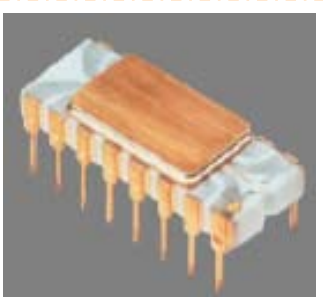

Fig. 61 - Chip Intel 4004

volver o primeiro microprocessador, o Intel 4004, com capacidade de processamento de 4 bits.

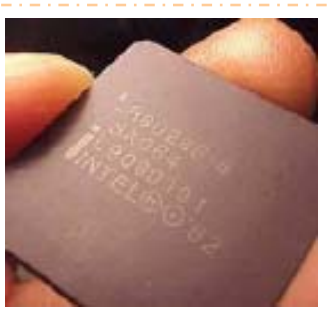

Fig. 62 - Microprocessador

Em 1971, os computadores de quarta geração dominaram o mercado, após surgirem os elementos que podem ser considerados os mais revolucionários neste setor: os microprocessadores e as unidades centrais de processamento - CPU (central processing unit) (IBIDEM, P. XXIX-XXX).

Um microprocessador é um chip de alta capacidade, com diversos circuitos, cada desempenhando uma determinada função do aparelho. Em uma única pastilha de silício (menor que uma polegada quadrada), podia-se abrigar até um milhão de circuitos diferentes, e essa quantidade evoluiria em progressão geométrica nos anos seguintes (GOOKIN ET AL., 1994, P. 239).

Patenteados em 71 pela Intel, os microprocessadores foram responsáveis por levar os "micros" aos lares, ao reduzir ainda mais custos e ampliar a capacidade de processamento destes.

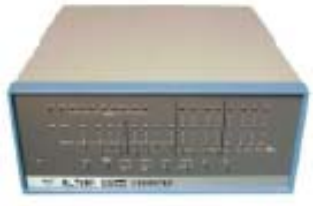

Fig. 63 - MITS Altair 8800

O primeiro computador com um microprocessador (Intel 8080) e custo abaixo de US\$ 400,00 foi o MITS Altair 8800 , da Micro Instruments and Telemetry Systems, de 1975. 


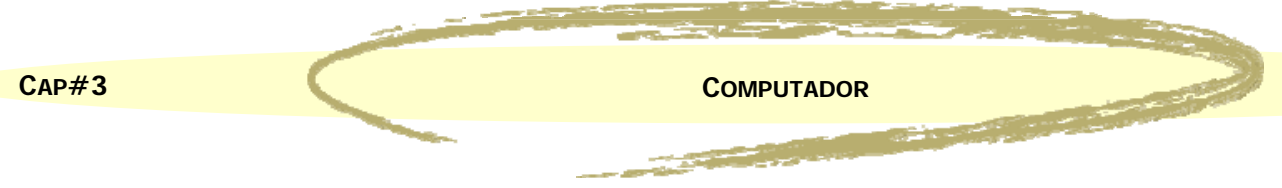

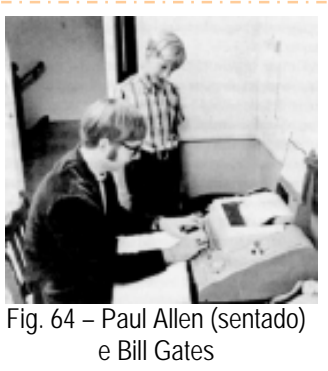

\section{XEROX}

Fig. 65 - Logotipo Xerox

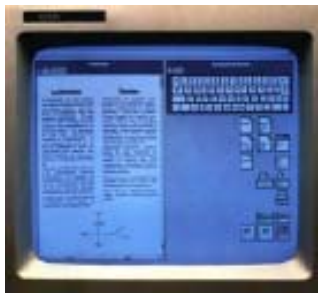

Fig. 67 - Interface gráfica

Sua linguagem de programação era o Qbasic (Quick Beginners All-purpose Symbolic Instruction Code, código rápido de instruções simbólica de uso geral para principiantes), desenvolvido pela recém-criada (também de 75) Microsoft, fundada por William Henry Gates III (Bill Gates) e Paul Allen.

Outro avanço marcante deste período foi o desenvolvimento do importante periférico chamado mouse. Em 1972, a Xerox Corporation decidiu criar um computador de alta performance, para uso exclusivo de seus funcionários, em sua unidade de Palo Alto, Texas.

Finalizado no ano seguinte, este computador de pesquisas, chamado Alto, trazia importantes criações, que

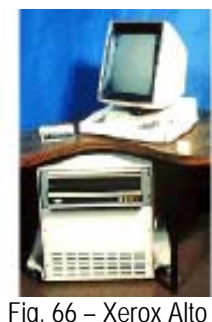
demorariam mais de dez anos para serem popularizadas: o mouse (criado já com três botões) e a interface gráfica, a maneira mais intuitiva de utilizar o equipamento, através de janelas, botões e ícones na tela do micro.

Infelizmente, o elevado preço do computador transformou-o em um fracasso de vendas, desestimulando o contínuo trabalho de desenvolvimento de software e hardware da equipe de Palo Alto, motivo provável da demora na difusão dos equipamentos criados pela Xerox. 


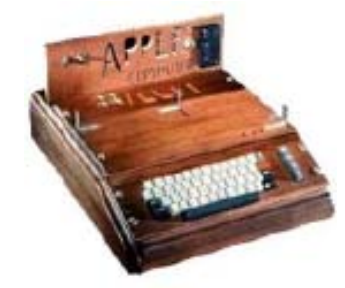

Fig. 68 - Apple I

Outro evento que contribuiu para a vulgarização do uso dos computadores, e sua própria evolução, foi o surgimento do Apple I, em 1976, para uso doméstico, seguido pelo seu expressivo sucesso de vendas. Este fato forçou a entrada da IBM, de forma contundente, neste mercado de

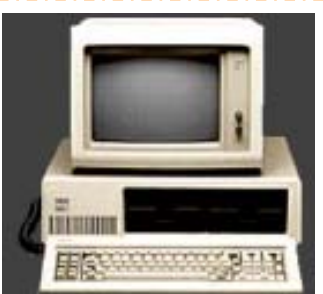

Fig. 69- IBM PC computadores, com o seu PC (Personal Computer - computador pessoal).

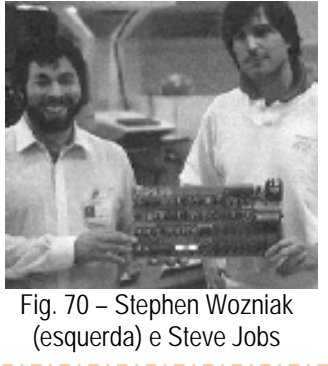

universidade e de trabalho, Stephen

Wozniak, a montar uma empresa

voltada à produção de micros, a Apple

(FREEDMAN, 1995, P. XXXIV). Wozniak

largou seu emprego de engenheiro da Hewlett Packard - HP e
Em 1976, Steve Jobs, 22 anos, convenceu seu ex-colega de aceitou a sociedade com Jobs, lançando o Apple I neste mesmo ano.

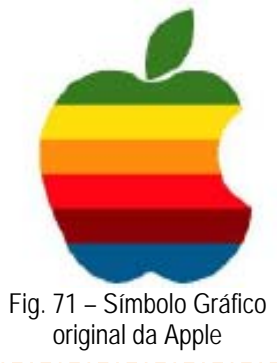

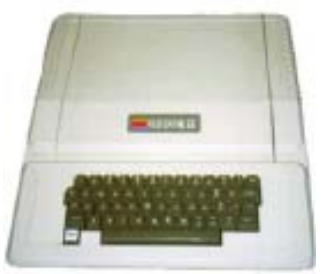

Fig. 72 - Apple II

Em 77, a dupla tomou um empréstimo bancário de US\$ 5.000 e investiu na montagem de um stand na primeira feira de computadores da costa oeste americana. Neste local, Wozniak e Jobs lançaram o Apple II, uma visível evolução do modelo anterior, que foi recebida entusiasticamente pelos consumidores, e a empresa começou a crescer. 


\section{Radro hrack \\ Fig. 73 - Logotipo Radio Shack

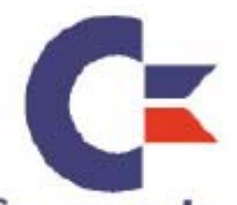 \\ Commodore}

Fig. 75 - Logomarca Commodore

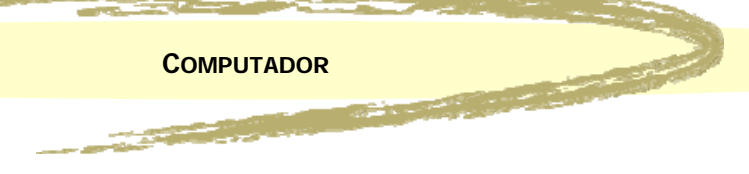

Ainda em 1977, começaram a surgir os primeiros concorrentes do Apple: a Radio Shack/Tandy Corp. lançou o TRS-80 (TRS vem de Tandy

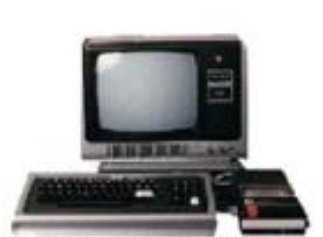

Fig. 74 - TRS-80

Radio Shack) e a Commodore exibiu o PET $^{*}$ - Personal Electronic Transactor, algo como "operador pessoal eletrônico". Nos quatro anos seguintes, dezenas de novos modelos e fabricantes

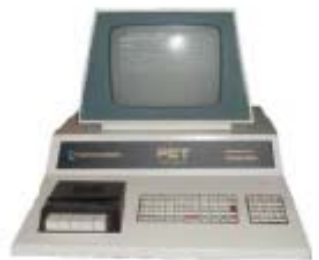

Fig. 76 - PET 2001

surgiram, atraindo grandes empresas para este mercado.

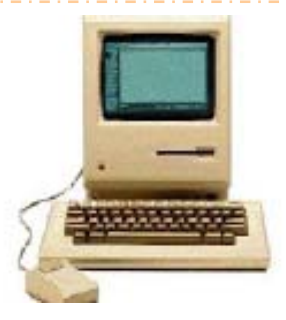

Fig. 77 - Apple Maclntosh

Em janeiro de 84, é lançado o MacIntosh e, nos primeiros cem dias, são vendidas 70 mil unidades, um dos maiores fenômenos de venda do setor; em abril, surge a versão portátil do

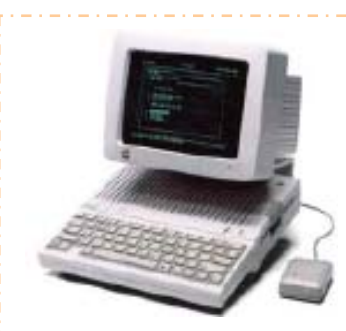

Fig. 78 - Apple Ilc

Apple II, batizado de Apple IIc.

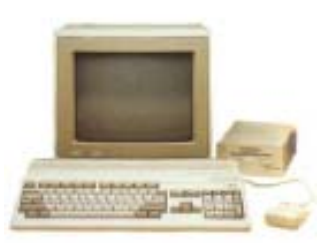

Fig. 79 - Commodore Amiga

No ano seguinte, a Commodore, que havia criado o PET para competir com o Apple, lança o Amiga contra o MacIntosh, inaugurando uma nova era na computação: a multimídia. O modelo contava com três chips diferentes para controlar som, vídeo e processamento independentemente; saída para televisão e vídeocassete, sistema integrado de áudio, multiusuário e multitarefa real (preemptiva), sistema

\footnotetext{
“Pet, em inglês, também significa "animal de estimação", numa alusão que este computador seria seu "fiel companheiro".
} 


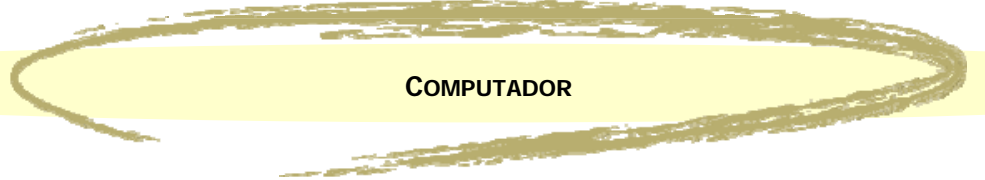

operacional gráfico... recursos que só seriam incorporados em Mac e PC mais de 10 anos depois! Felizmente para Apple e IBM, poucos levaram o Amiga a sério (a própria Commodore era descrente), e o computador foi rotulado como um "caro videogame" (tão comum na época); produto e empresa acabaram por sumir do mercado.

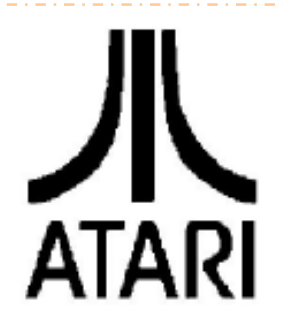

Fig. 80 - Logomarca Atari

Destino parecido atingiu outra novidade, surgida apenas alguns meses antes do Amiga: o Atari. A empresa era uma das gigantes em videogames, o que dificultou a aceitação do produto para

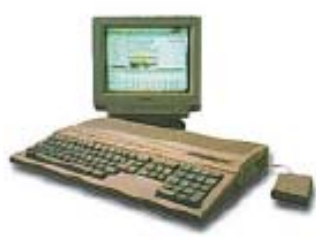

Fig. 81 - Atari 520ST

uso "educacional ou profissional". O computador Atari ainda foi pego em um fogo cruzado pesado entre Mac e PC, mais baratos para uso geral, e o Amiga, insuperável como "videogame" (leia-se "recursos gráficos"). Com o tempo, o Atari achou um pequeno nicho de mercado entre músicos e profissionais de efeitos sonoros, mas o volume de vendas foi insuficiente para manter a linha de produção.

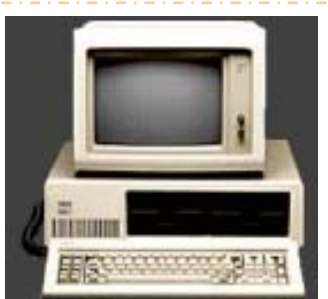

Fig. 82 - IBM PC

Em agosto de 1981, cinco anos atrás de seus maiores concorrentes (principalmente a Apple Computers Inc.), a IBM finalmente entra na "guerra" pelos microcomputadores. Neste ano, ela apresenta o PC (de Personal Computer,

ou computador pessoal) (IBIDEM, P. XXXV), com tecnologia de 16 bits, que se tornaria, em pouco tempo, um padrão de mercado. Dois anos

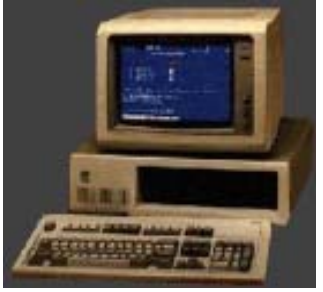

Fig. 83 - IBM PC-XT depois, no mês de fevereiro, surge um novo modelo, o IBM PC-XT (de eXtended Tecnology, ou tecnologia estendida). 


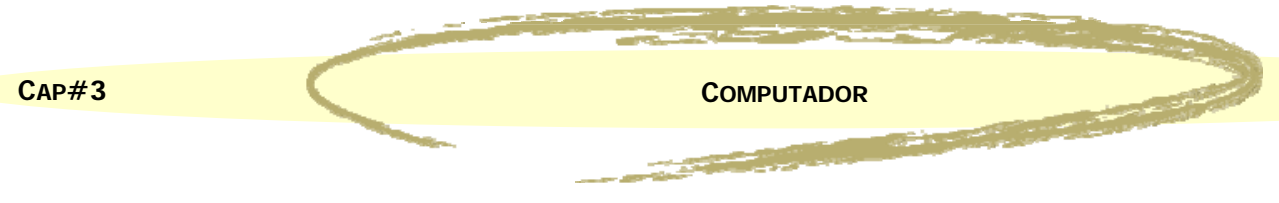

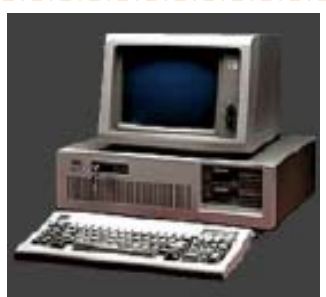

Fig. 84 - IBM PC-AT

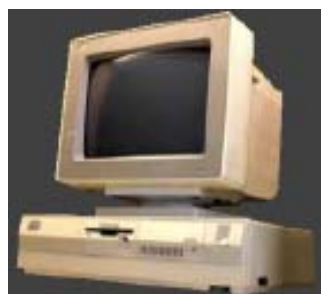

Fig. 85 - IBM PS/2

Em 1984, a IBM já detinha metade do mercado. Em agosto deste mesmo ano, a empresa lançou o PC-AT (Advanced Tecnology, ou tecnologia avançada); nesta época, o PC já era o padrão de microcomputadores, contando com o maior parque instalado no mundo.

Em abril de 87, a IBM anuncia uma nova série de micros, para substituir a linha PC: a família PS/2 (Personal System/2, ou sistema pessoal/segunda versão); apesar do novo nome, continua-se a chamar os computadores, até hoje, de "compatíveis com IBM PC" (o correto seria chamá-los de "compatíveis com IBM PS/2"...).

A partir deste período (final da década de 80), o padrão de computadores não mudou, apenas evoluíram os equipamentos: 286, 386, 486, Pentium, Celeron, Duron, Athlon... são apenas versões mais poderosas do microprocessador IBM/Intel PS/2 original; paralelamente, PowerPC/PowerMac, Quadra, G3... são só evoluções do processador Apple MacIntosh original (CF. HTTP://WWW.CLUBEDOHARDWARE.COM.BR/ARTIGOS/492 E HTTP://WWW.CLUBEDOHARDWARE.COM.BR/ARTIGOS/993, ACESSADOS EM 30 DE MAIO DE 2006).

Outros fatores, além da velocidade de processamento, também influenciaram o avanço da informática: memória de processamento (RAM) e armazenamento (HD) também evoluíram em capacidade e velocidade, e são também fundamentais para os programas que hoje utilizamos, especialmente na área gráfica, notória por consumir qualquer recurso disponível no computador. 


\section{A informática tem seu lado "soft"...}

O micro, per se, não tem sentido sem uma aplicação, um programa. Os programas são, usualmente, separados em sistemas operacionais e aplicativos. Dentro destas categorias, existem ainda algumas subdivisões e diversos modelos.

Os sistemas operacionais, também conhecidos como "plataformas", fazem a interface entre o equipamento e o usuário: controlam teclado, mouse e monitor, bem como comandam processadores, pentes de memória, dispositivos de armazenamento... e aplicativos. Os aplicativos, ou softwares, são programas especializados, que orientam o computador, por intermédio do sistema operacional, a perfazer uma determinada tarefa ou atingir um resultado esperado.

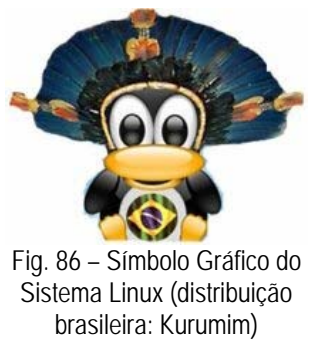

Os softwares de design são inúmeros, sejam para a área de produto ou gráfica; divisões, subdivisões e nichos apenas organizam esta quantidade de opções. Usualmente, separamos os aplicativos por plataformas: programas para Windows, MacOS, Linux, Unix... além dos "híbridos", que funcionam em dois ou mais sistemas diferentes.

Dentre estas categorias, diversas divisões surgem: há aplicativos específicos para desenho bi e tridimensional, diagramação de textos, editoração eletrônica, retoque de fotografias, renderização, pintura digital, apresentação eletrônica... e criação de identidade visual.

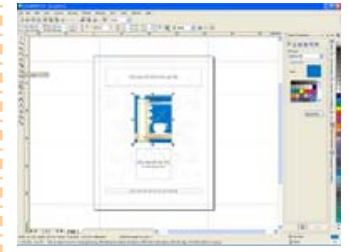

Fig. 87 - Tela do CorelDraw

Especificamente na área de branding, os mais conhecidos programas para desenvolver logotipos, logomarcas e símbolos gráficos são CorelDraw, Illustrator e FreeHand, chamados de softwares de edição vetorial, que trabalham os conceitos matemáticos do desenho, como círculos, linhas, sólidos, entre outros. 


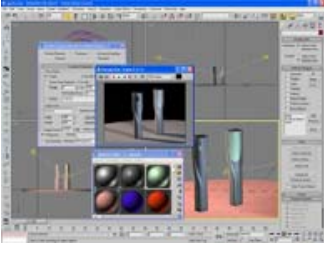

Fig. 88 - Tela do 3DMax

Além destes programas principais, ainda como suporte à ilustração, temos numerosos aplicativos voltados a edição de imagens e animação: PhotoShop (retoques fotográficos), Flash (animação e interação), Painter (efeitos de pintura), 3DMax (efeitos tridimensionais e foto-realismo), DreamWeaver (criação de páginas para Internet)...

A lista poderia ser interminável, dependendo da preferência de cada designer, pode-se observar, entretanto, que não é recomendado ater-se a um único aplicativo, pois cada um apresenta suas características e recursos próprios.

O mais indicado é que o profissional de design detenha o conhecimento básico da mais variada gama de programas possível, especializando-se, sim, naqueles softwares que apresentem os recursos mais utilizados no seu dia-a-dia. Deste modo, o designer poderá buscar um ou outro determinado efeito quando necessário, apelando para literatura especializada ou colegas que conheçam tal aplicativo com maior profundidade. Neste sentido, a interação e troca de experiências é fundamental para o sucesso do designer moderno.

\section{Resumindo}

A tecnologia de produção de chips continua evoluindo com rapidez espantosa. Os custos dos novos chips são cada vez menores, a escala de integração e a capacidade de processamento destes crescem exponencialmente, os incentivos de governos, empresas e universidades para pesquisas nesta área são constantes. 


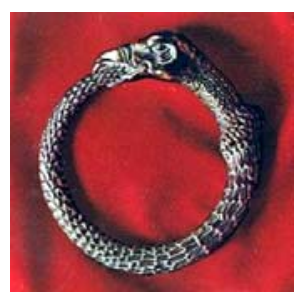

Fig. 89 - A "relação" software-hardware
Os softwares, por sua vez, também evoluem com velocidade espantosa, especializando-se progressivamente e acrescentando numerosos efeitos a cada nova versão; tal evolução, porém, consome cada vez mais recursos de hardware, tornando-se um moto continuum: novos efeitos, novas necessidades, novos equipamentos, novas oportunidades, novos efeitos, novas necessidades...

Fundamental, pois, é que o designer permaneça atualizado, tanto em relação aos aplicativos quanto aos equipamentos, bem como no hábil manejo destes, para que mantenha a competitividade e agilidade que o mercado exige hoje. Evitando excessos, claro, pois o custo de tal processo pode ser muito proibitivo.

E esta fantástica ferramenta "veio para ficar": é cada dia mais inconcebível dispensá-la no modus operandi do designer atual. Dominá-1a, como se aprende a manejar uma caneta tinteiro ou um conjunto de esquadros, é igualmente fundamental para o profissional da área gráfica, especialmente se atingida a mesma habilidade do manuseio de uma caneta ou régua. 


\title{
O banco de todos os brasileiros
}

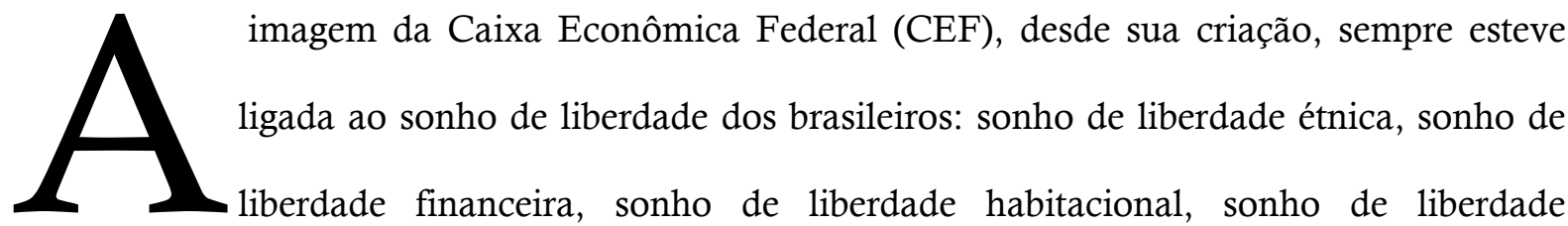
trabalhista...

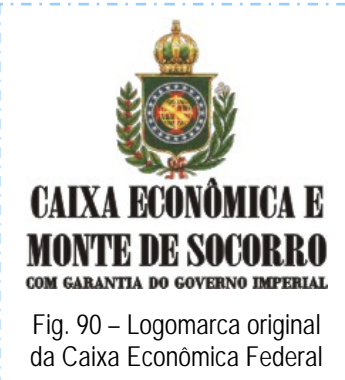

\author{
A "Caixa Econômica e Monte \\ de Socorro" (sua denominação original) \\ foi criada em 12 de janeiro de 1861, pelo \\ Imperador Dom Pedro II, no Rio de \\ Janeiro, pelo Decreto $\mathrm{n}^{\mathrm{o}}$ 2.723, para
}

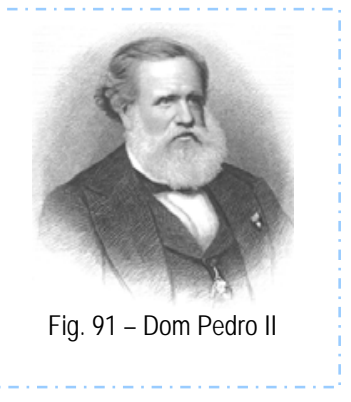

conceder empréstimos sob penhor e incentivar poupança popular. O intuito do Imperador era oferecer uma opção viável para a população carioca, uma vez que existiam, na Capital Imperial, 
diversas casas de empréstimos, mas que não ofereciam garantias aceitáveis ou cobravam juros exorbitantes (CF. HTTP://WWW.CAIXA.GOV.BR/ACAIXA/HISTORIA_MISSAO.ASP, ACESSADO EM 02 DE JUNHO DE 2006).

Rapidamente, porém, ela se tornou uma forma de escravos economizarem qualquer quantia monetária ganha, visando $\mathrm{o}$ montante suficiente para "comprar" sua liberdade e de familiares e amigos (as cartas de alforria), até o fim oficial da escravidão, pela própria filha de Dom Pedro II, Princesa Isabel, com a Lei Áurea,

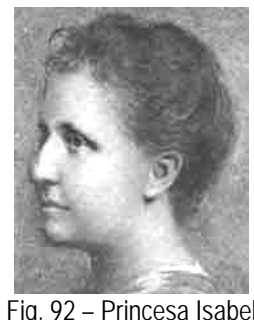

Fig. 92 - Princesa Isabe em 13 de maio de 1888 .

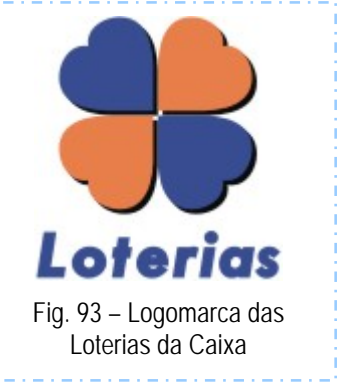

Em 1934, por determinação do governo federal, a Caixa assumiu a exclusividade dos empréstimos sob penhor, com a conseqüente extinção das casas de prego operadas por particulares (RIBEIRO, 1997, P. 97). Com cem anos de existência, em 1961, a empresa começou a operar, também com monopólio, as loterias, e o brasileiro "apostou" no sonho da liberdade financeira...

Até 1970, as Caixas Econômicas Federais incorporavam o nome do estado (Caixa Econômica Federal de São Paulo, Caixa Econômica Federal do Rio Grande do Sul...) e detinham uma elevada autonomia do governo federal (IDEM, P. 2-7); neste ano, ocorreu a unificação sob uma só denominação, pelo decreto lei no $\mathrm{n}^{\mathrm{o}} 759$,

\section{WBNH}

Fig. 94 - Logomarca do Banco Nacional da Habitação extinguindo as Caixas Federais nos Estados (IDEM, P. 185). Desesseis anos depois, em 86, o Banco Nacional da Habitação - BNH também foi extinto, com seu pessoal e suas funções sendo incorporados pela Caixa. A empresa, então, se tornou o maior agente nacional de financiamento imobiliário e importante financiadora do desenvolvimento urbano 


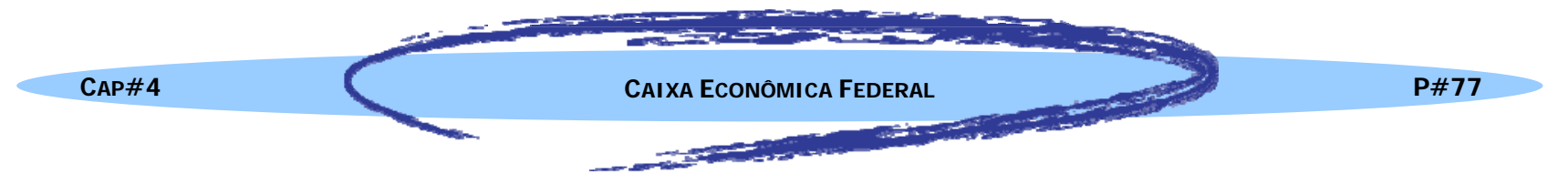

(CF. HTTP://WWW.CAIXA.GOV.BR/ACAIXA/HISTORIA_MISSAO.ASP, ACESSADO EM 02 DE JUNHO DE 2006), fazendo o brasileiro sonhar com a casa própria.
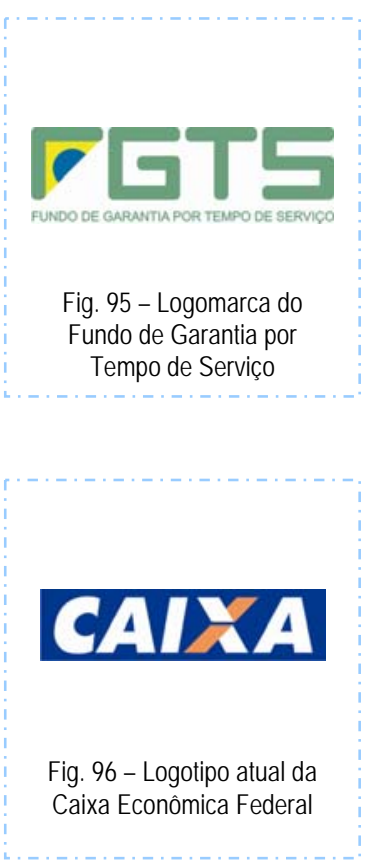

Caixa Econômica Federal

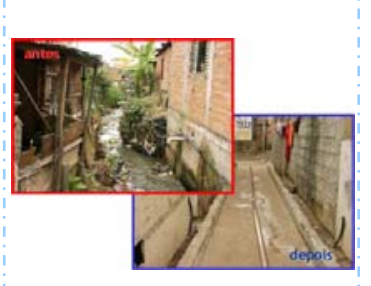

Fig. 97 - Melhorando a vida dos brasileiros
Pouco depois, já em 1990, ela centraliza quase 130 milhões de contas do Fundo de Garantia por Tempo de Serviço - FGTS, geridas anteriormente pelo BNH e até então distribuídas em outros 76 bancos (IBIDEM), e o brasileiro passa a ver a Caixa Econômica Federal como o sonho da aposentadoria.

Mais do que a importância desta instituição financeira na vida de nosso povo, estas passagens ilustram que o perfil da Caixa mudou com o tempo; muitas destas mudanças foram acompanhadas de renovações em sua própria imagem corporativa, registrando o impacto que tais eventos causaram na empresa.

\section{Missão da empresa}

Essencialmente, a missão da Caixa é:

"[...] promover a melhoria contínua da qualidade de vida da população brasileira, intermediando recursos e negócios financeiros, atuando no fomento ao desenvolvimento urbano e nos segmentos de habitação, saneamento e infra-estrutura, e na administração de fundos, programas e serviços de caráter social, tendo como valores fundamentais:

- Direcionamento de ações para 0 atendimento das expectativas da sociedade e dos clientes;

- Busca permanente de excelência na qualidade dos serviços oferecidos;

- Equilíbrio financeiro em todos os negócios;

- Conduta ética pautada nos valores da sociedade;

- Respeito e valorização do ser humano" (IBIDEM). 


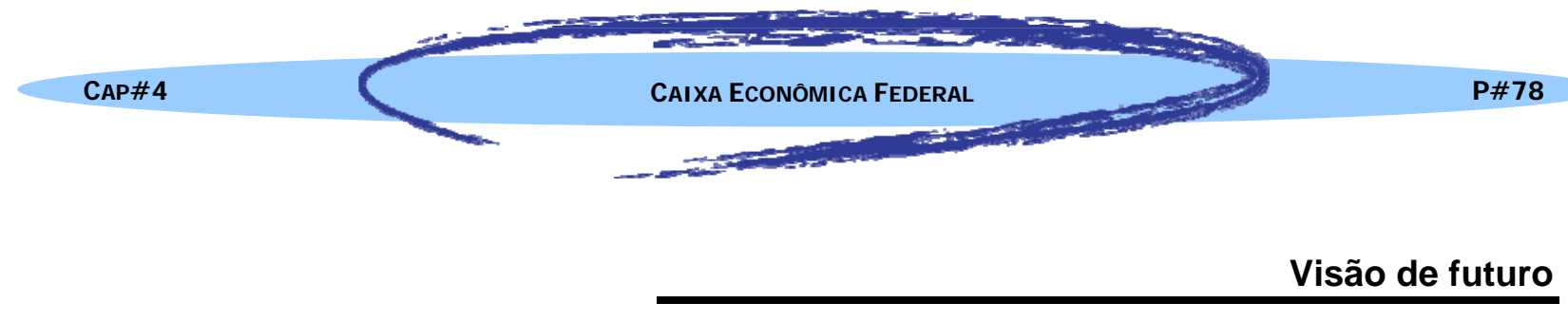

Paralelamente, a visão de futuro da empresa se apresenta embasada nos seguintes tópicos:

- "A Caixa será referência mundial como banco público integrado, rentável, socialmente responsável, eficiente, ágil e com permanente capacidade de renovação.

- Manterá a liderança na implementação de políticas públicas e será parceira estratégica dos governos estaduais e municipais.

- Consolidará sua posição como o banco da maioria da população brasileira, com relevante presença no segmento de pessoa jurídica e excelente relacionamento com seus clientes.

- Será detentora de alta tecnologia da informação em todos os canais de atendimento e se destacará na gestão de pessoas, reconhecidas em seu mérito, capacitadas e com desenvolvido espírito público.

- Manterá relacionamentos sólidos, coesos e inovadores com parceiros competentes e de forte compromisso social" (IBIDEM, GRIFOS NOSSOS).

Pelos trechos destacados acima, a presença do computador no dia-a-dia da empresa, e para seu futuro, é fundamental. De fato, ele é ferramenta importante em diversas tarefas, nos mais variados setores da empresa, sendo a Tecnologia uma área estratégica em seu planejamento.

\section{Código de ética}

O Código de Ética da Caixa expressa o sentimento de seus empregados, externado em pesquisa realizada entre estes, que validou os valores presentes na empresa:

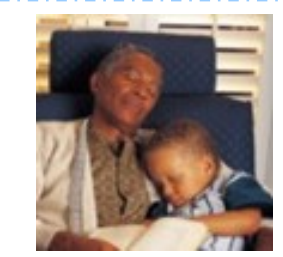

Fig. 98 - O Código de Ética garante a tranqüilidade do cliente da Caixa
- Respeito

- Honestidade

- Compromisso

- Transparência

- Responsabilidade (CF. HTTP://UnIVERSIDADECORPORATIVA.CAIXA/ (INTRANET), ACESSADO EM 05 DE JUNHO DE 2006)

Estes valores norteiam a atuação da CEF em todas suas formas de atuação: com clientes, funcionários, parceiros, órgãos públicos, empresas... 


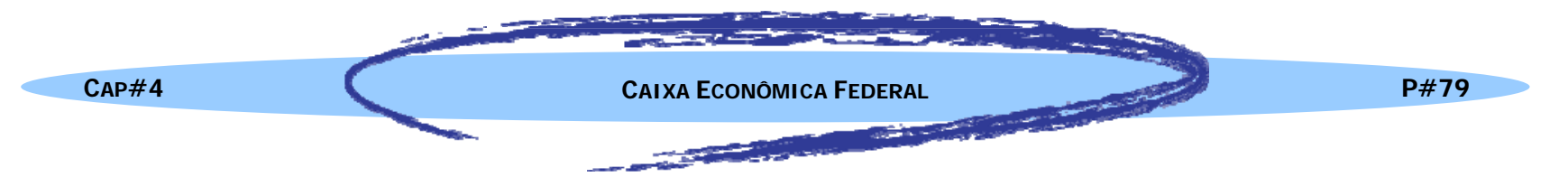

Caixa Cultural

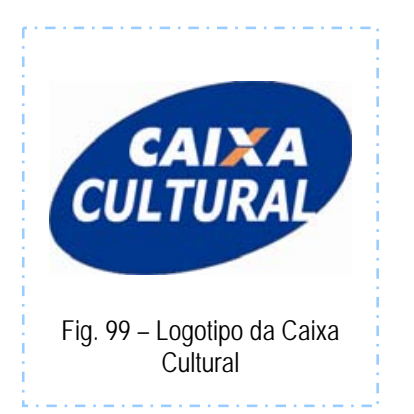

Promover a inclusão social é, neste sentido, um de seus principais objetivos. E uma das melhores formas de torná-la realidade é o apoio a iniciativas artístico-culturais, educacionais e desportivas, principalmente aquelas que tenham identidade com a finalidade social da empresa.

\section{Caixa de artes}

Incentivadora da cultura e de toda manifestação artística, a Caixa tem papel fundamental nas obras hoje ao alcance do público. Artes cênicas e plásticas, música, esporte, congressos, seminários, fóruns, simpósios, encontros e ações sociais; são essas as principais atividades que vêm recebendo o patrocínio da empresa.

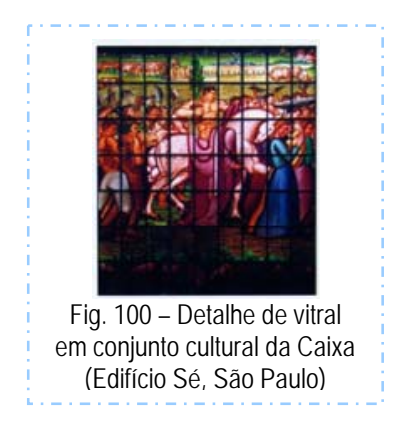

A Caixa tem uma das mais completas coleções de obras de arte e documentos que retratam as atividades econômico-financeiras do país. O acervo possui "mais de mil obras, entre pinturas, gravuras, desenhos, tapeçarias, esculturas e painéis; e cerca de seis mil peças antigas relacionadas à trajetória da empresa e do próprio país [...]" (HTTP://WWW.CAIXA.GOV.BR/ACAIXA/CULTURA.ASP, ACESSADO EM 05 DE JUNHO DE 2006). 


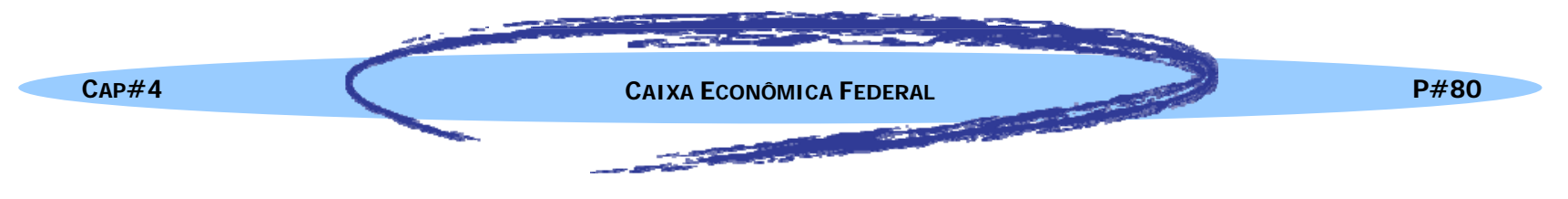

Com o objetivo de divulgar as artes plásticas às diversas camadas da população brasileira, que normalmente não têm acesso às obras de artistas famosos, a Caixa montou exposições itinerantes monitoradas com as principais obras de seu acervo, que vêm sendo apresentadas em suas galerias e espaços públicos em todos os estados brasileiros, com visitação aberta e gratuita, contribuindo para a disseminação da cultura nacional.

No início da década de oitenta, de forma a resgatar a cultura e certos ícones do patrimônio cultural nacional, o Conjunto Cultural da Caixa ganhou vida, inicialmente em Brasília, e hoje retrata a história política, econômica, artística e cultural do nosso país. Com um "trabalho minucioso e dedicado, [...] essas histórias são contadas e vivenciadas no Museu da Caixa, que possui um grande número de obras e documentos relacionados à história do Brasil" (IBIDEM).

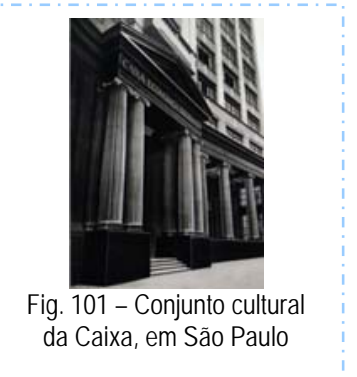

da Caixa, em São Paulo

Os espaços culturais da Caixa - teatros, galerias de arte e museus - localizam-se em Brasília, Curitiba, Rio de Janeiro, Salvador e São Paulo e estão voltados para a discussão de questões pertinentes à atualidade, estimulando a pesquisa e o desenvolvimento artístico do país e contribuindo para divulgar a cultura brasileira.

\section{Caixa de esportes}

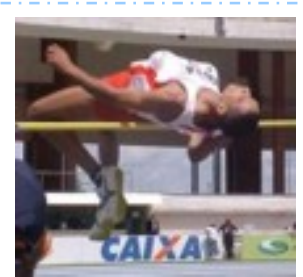

Fig. 102 - A Caixa e 0 atletismo
Como patrocinadora oficial do atletismo brasileiro, a Caixa descobre talentos, forma atletas e ajuda a lançar novos campeões no Brasil e no mundo. Mais do que isso, promove a inclusão social, ao investir numa modalidade esportiva democrática e acessível a todos os cidadãos. 


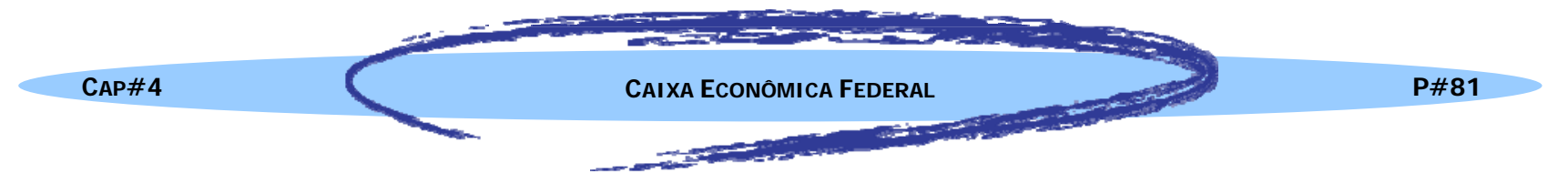

\begin{abstract}
"O contrato firmado com a Confederação Brasileira de Atletismo - Cbat, garante à Caixa exclusividade como instituição bancária patrocinadora do atletismo brasileiro, das Seleções Brasileiras de Atletismo, dos eventos do calendário esportivo nacional, e das duas etapas do Grand Prix Internacional de Atletismo" (HTTP://WwW.CAIXA.GOV.BR/ACAIXA/ATLETISMO.ASP, ACESSADO EM 05 DE JUNHO DE 2006).
\end{abstract}

Com o patrocínio, atletas e treinadores têm uma ajuda de custo mensal, fornecimento de material esportivo oficial e material promocional da Caixa, realização das competições nacionais e regionais e apoio a programas voltados para atletas, ex-atletas, técnicos e iniciantes do esporte.

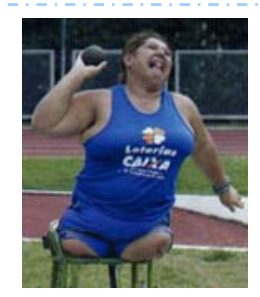

Fig. 103 - As Loterias e 0 paradesporto

Por meio das Loterias, a Caixa também patrocina o Comitê Paraolímpico Brasileiro - CPB e os atletas do paradesporto atletismo, natação e judô - que mais se destacaram segundo critérios técnicos definidos pelo próprio CPB. Somente entre 2003 e o primeiro semestre de 2005 , cerca de $\mathrm{R} \$ 30$ milhões foram investidos (HTTP://WWW.CAIXA.GOV.BR/ACAIXA/INDEX.ASP, ACESSADO EM 02 DE JUNHO DE 2006).

\title{
Caixa ambiental
}

A ética e a responsabilidade ambiental são valores que pautam a sustentabilidade dos negócios da Caixa. Além de ser a principal gestora das políticas de desenvolvimento urbano, habitação e saneamento do Governo Federal, a Caixa tem aperfeiçoado suas formas de gestão ambiental. Uma conseqüência desses fatos é o aporte de recursos e o envolvimento com eventos e projetos de cunho sócio-ambiental, em sintonia com as diretrizes do Governo Federal.

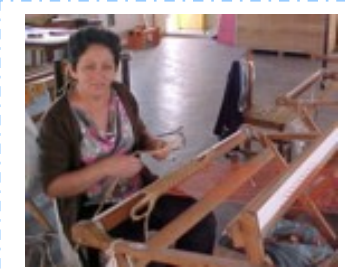

Fig. 104 - Apoio às comunidades carentes
Ainda neste sentido, todos os projetos habitacionais em que a empresa se envolve, seja pelo financiamento para construção, pela avaliação, venda ou outro fim qualquer, passa por minuciosa análise de impacto ambiental. Recentemente, em 2005, uma série de 
simpósios e oficinas de trabalho foram levadas a efeito, envolvendo os Ministérios Públicos Federal e Estadual paulista, bem como prefeituras municipais com questões ambientais relevantes, como as regiões dos Vale dos rios Ribeira e Guaraqueçaba e dos mananciais da área metropolitana de São Paulo. Estes encontros visam analisar cada situação em particular, de forma a extrair, de cada caso, a melhor atuação e os parceiros ideais para alcançar o tão almejado desenvolvimento sustentável. 


\section{Usos do computador}

O computador é ferramenta fundamental em todas as áreas da Caixa hoje: segurança, controle, atendimento, habitação, saneamento... todos setores o utilizam em suas atividades. A empresa tenta manter-se atualizada em relação à informática, notoriamente na área negocial, responsável pelo contato direto com o cliente.

As atualizações de imagem da empresa também exploraram o "estado da arte" das técnicas e da tecnologia vigentes em cada momento histórico, de forma a transmitir uma imagem de instituição bancária moderna, sólida, segura, que sabe aproveitar tudo que se desenvolve de mais novo a cada momento.

Porém, existe também um lado desfavorável desta ampla informatização dos serviços bancários: a intolerância ao erro. Ou, pelo menos, a falta de previsão de margem de manobras em relação a este: alguns dos sistemas de dados do banco não permitem discrepância de valores, mesmo na casa dos centavos, sendo necessárias verificações constantes dos mesmos.

Ainda assim, não se pode imaginar o trabalho bancário sem a presença maciça de computadores, em diversas áreas e sob diferentes formas de atuação.

Tecnologia e segurança

A fim de assegurar uma execução mais eficiente das políticas sociais, a Caixa desenvolveu o Cadastro Único, "ferramenta capaz de apresentar informações sobre o perfil sócioeconômico de aproximadamente 53,5 milhões de pessoas situadas abaixo da linha de pobreza" (IBIDEM). 


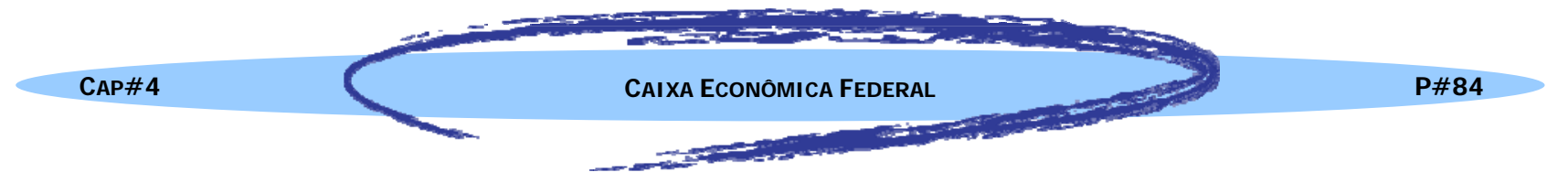

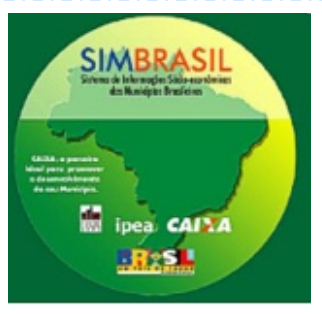

Fig. 105 - Simbrasil

Desde 2004, a Caixa mantém acordo de cooperação técnica com o Instituto de Pesquisas Econômicas Avançadas - IPEA para desenvolvimento do Sistema de Informações Sócio-Econômicas dos Municípios Brasileiros - Simbrasil (CF. HTTP://WwW.IPEA.GOV.BR, ACESSADO EM 12 DE JUNHO DE 2006). Sob a forma de um CD-ROM, distribuído gratuitamente nas agências do banco, o Simbrasil traz um retrato sintético de cada município do país, com dados fiscais, econômicos, demográficos, educacionais, urbanos e sociais, ferramenta importante para identificar, avaliar, diagnosticar, gerenciar e planejar soluções para suas principais dificuldades. Inclusive as melhores maneiras e áreas de aplicação dos recursos oriundos dos programas da Caixa.

Por fim, o site www . caixa.gov.br/seguranca/ dá importantes dicas para proteger o cliente em todas as formas de atendimento bancário: agência, caixa eletrônico, internet banking, navegação na internet... Recomenda-se a leitura de tal material, mesmo para aqueles que não são clientes da Caixa: o acesso é disponível para todos os interessados.

Tecnologia e atendimento

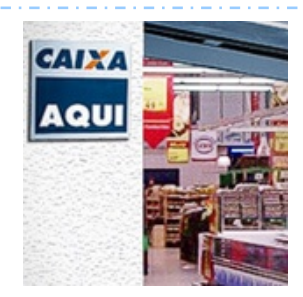

Fig. 106 - Correspondente bancário

novos correspondentes

\begin{abstract}
A Caixa se destaca quando o assunto é atendimento: sua rede, a maior do país, abrange todos os 5.561 municípios brasileiros, "com mais de 17 mil pontos de atendimento, entre agências, lotéricas e correspondentes bancários. Em 2003, iniciou-se o projeto de instalação de 500 novas agências, das quais mais de 150 já estão funcionando. Quase 3,5 mil
\end{abstract} (HTTP:I/WWW.CAIXA.GOV.BR/ACAIXA/INDEX.ASP, ACESSADO EM 02 DE JUNHO DE 2006), todos com atendimento 
informatizado. Para quem prefere outros canais, a Caixa também oferece terminais eletrônicos, Banco 24h, Caixa Rápido, débito automático, atendimento telefônico e Internet Banking Caixa.

Até mesmo quem está fora do Brasil pode contar com a

\section{Millennium}

Fig. 107 - Logotipo do Millennium BCP
Caixa: desde 2004, os brasileiros residentes no exterior podem utilizar o Caixa Internacional para fazer remessas de recursos ao país. No ano seguinte, um convênio com o Millennium $\mathrm{BCP}$ português garantiu ainda mais facilidade nesse processo

(HTTP://WWW.CAIXA.GOV.BR/ACAIXA/INDEX.ASP E HTTPS://INTERNETCAIXA.CAIXA.GOV.BR/NASAPP/SILOJ/INDEX.DO, ACESSADOS ENTRE 02 E 09 DE JUNHO DE 2006).

A Caixa opera e paga os benefícios provenientes do Bolsa Família, programa de transferência de renda do governo federal, entre outros. "Em 2004, foram efetuados 47 milhões de pagamentos da bolsa, totalizando $R \$ 3,3$ bilhões. Até o final de 2006, espera-se que mais de 11 milhões de familias carentes sejam atendidas pelo programa" (HTTP:/IWwW.CAIXA.GOV.BR/ACAIXA/INDEX.ASP, ACESSADO EM 02 DE JUNHO DE 2006). O gerenciamento destes benefícios só se torna possível com a utilização do computador como ferramenta de controle e fiscalização.

\section{Tecnologia e ensino}

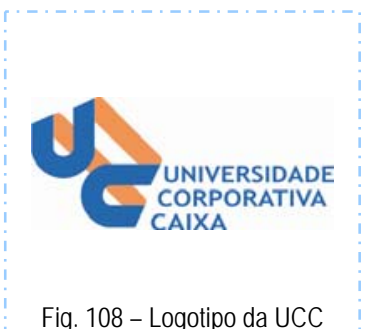

Fig. 108 - Logotipo da UCC
Desde 1996, a empresa conta com a Universidade Corporativa Caixa - UCC, cuja missão é "fomentar o aprendizado contínuo e o desenvolvimento de competências, objetivando o alcance de resultados sustentáveis para as pessoas, para a Caixa e para a sociedade" (HTTP://UNIVERSIDADECORPORATIVA.CAIXA/ [INTRANET], ACESSADO EM 05 DE JUNHO DE 2006).

Iniciando com o Programa Crescer, que propunha "a inclusão de novos elementos na cultura educacional, como a atuação dos gestores como líderes educadores, a co-responsabilidade do aprendiz pelo seu 
desenvolvimento e o foco em resultados sustentáveis" (IBIDEM), evoluiu paulatinamente em direção ao ensino on-line, pela Intranet, transformando-se no site da UCC; desde 2005, a Universidade Corporativa Caixa conta com um edifício próprio, em São Paulo, para centralizar cursos presenciais, sem, contudo, invalidar ou menosprezar os cursos virtuais. Neste último contexto, a utilização de computadores é de importância ímpar, concentrando, em si, instrutor, material didático e sala de aula.

O ensino, ministrado pela UCC, foi desenvolvido com modelo pedagógico próprio, centrado "no aprendiz, na aprendizagem significativa e no desenvolvimento de competências" (IBIDEM), e está baseado em 15 premissas educacionais, entre elas:

- A valorização, em todos os níveis da Caixa, da cooperação, da integração, da transparência nas ações, da atuação em equipe, do espírito público e da gestão de pessoas;

- 0 aproveitamento e o desenvolvimento do saber, dos aspectos culturais desejáveis e da experiência individual e das equipes da Caixa, no processo de reconstrução cultural e formação de opinião;

- 0 reconhecimento de que aprender é um processo contínuo e de que é na interação entre as pessoas e situações vivenciadas no dia-a-dia que 0 aprendizado se consolida;

- 0 desenvolvimento de competências individuais e coletivas que sustentem as competências essenciais da Caixa e garantam resultados sustentáveis;

- 0 desenvolvimento de competências e sua efetividade dentro de um contexto educacional que estimule 0 espírito crítico, criativo e empreendedor e respeite a autonomia dos sujeitos (IBIDEM). 


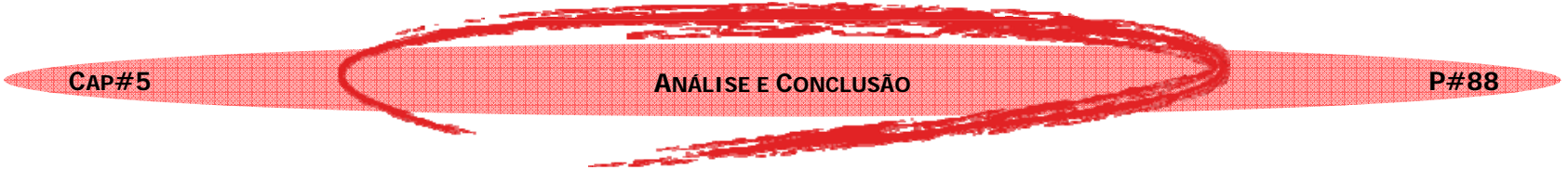

Aplicações da marca

$\mathrm{N}$ concorrentes, era praticamente nulo: existiam poucos concorrentes com o porte da Caixa naquela época!

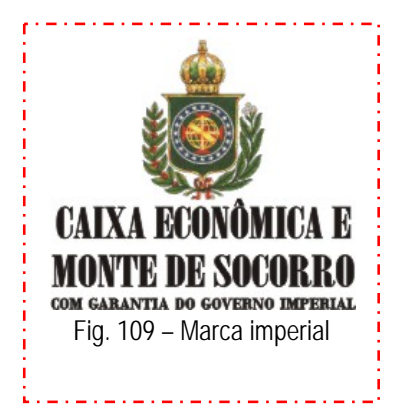

A identidade corporativa da em-
presa restringia-se ao brasão nacional
(fosse imperial ou republicano, depen-
dendo do período) com a subscrição de
sua denominação formal ("Caixa Eco-

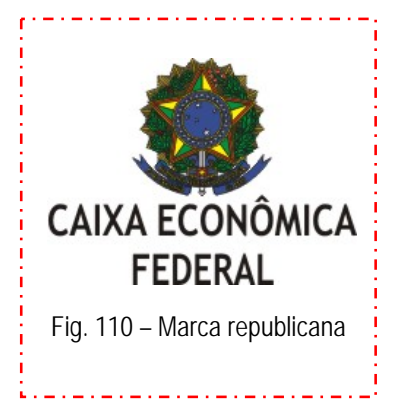

nômica e Monte de Socorro", no Império, ou "Caixa Econômica Federal”, na República). 
Com o tempo, surge a necessidade que implicou na valorização da imagem da empresa. O brasão da República não era suficiente para identificar uma empresa estatal, e tornou-se gradualmente importante investir em uma marca própria, que diferenciaria a imagem do banco da do governo e identificaria, ao mesmo tempo, o perfil da empresa.

\section{Evolução da marca corporativa}

Este é o "histórico visual" da marca da Caixa, com respectivos autores e períodos de uso.

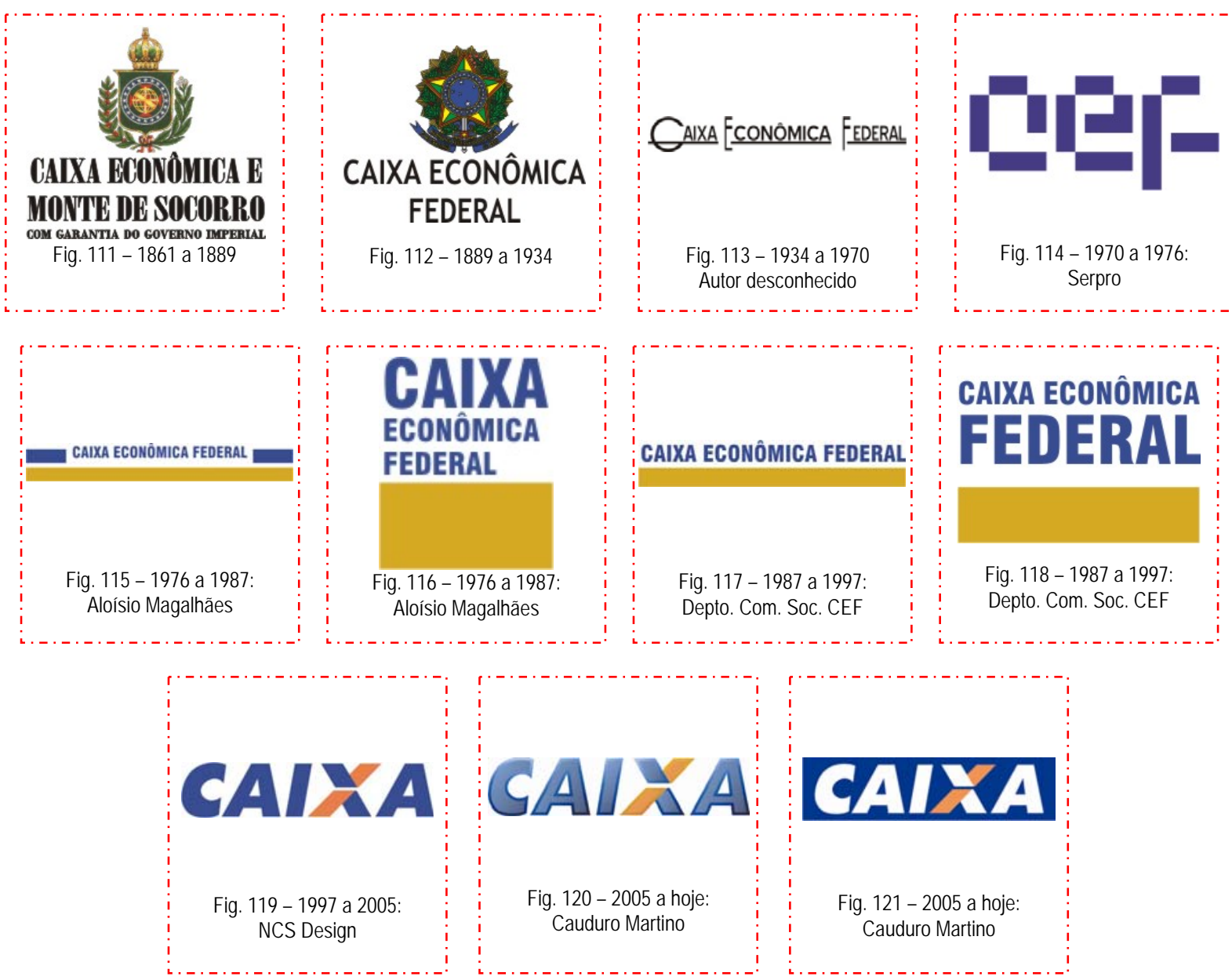

Destas, nem todas apresentam influência direta da ferramenta computador. Será mostrado que os logotipos desenvolvidos nos anos de 1970, 1987, 1997 e 2005 apresentam elementos que denotam tal tendência, ainda que cada um de forma e intensidade específicas. $\mathrm{O}$ 
logo de 1976 não foi influenciado por essa ferramenta, enquanto os brasões, criados há mais de 100 anos, certamente não apresentam tal influência.

\section{A influência do computador}

A seguir, serão apresentados os aspectos que denotam influência da ferramenta computador, exemplificando com os logos da Caixa, quando possível, e de outras empresas, quando tais aspectos não sejam contemplados pela identidade corporativa da CEF.

\section{Uso de desenho vetorial}

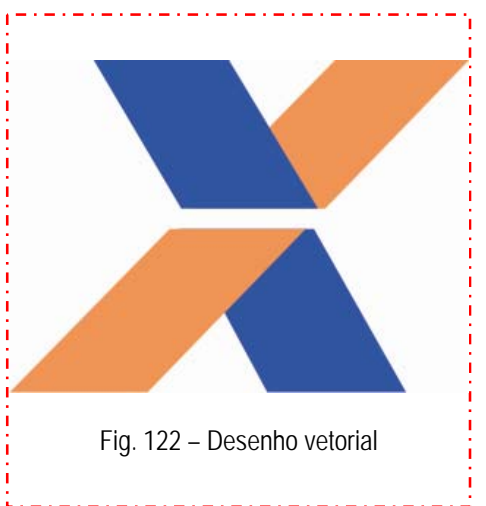

Eis um dos elementos mais vantajosos do uso do computador: o desenho vetorial. Este tipo utiliza fórmulas matemáticas para compor seu resultado final. Apesar de exigir maior capacidade de processamento do micro (todas as fórmulas precisam ser constantemente recalculadas), tal processo apresenta a vantagem de poder facilmente ser reduzido ou ampliado para qualquer escala, sem perda de qualidade.

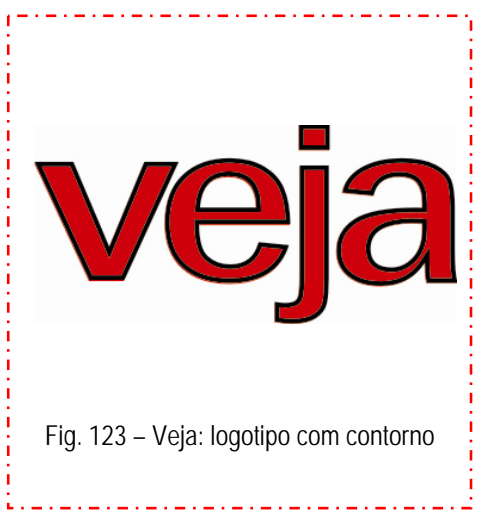

Tradicionalmente, tais desenhos são compostos por contornos e preenchimentos, que podem ser alterados de acordo com a necessidade específica de cada projeto, de forma clara e precisa. A aplicação de efeitos como sombra, brilho, relevo, textura e gradientes cromáticos valoriza esteticamente determinados elementos de uma marca. 


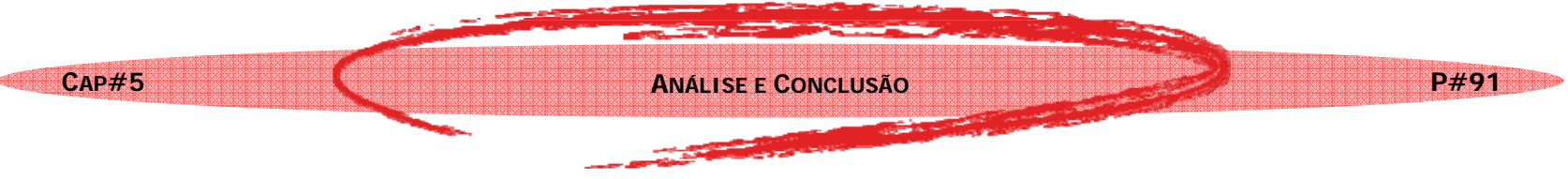

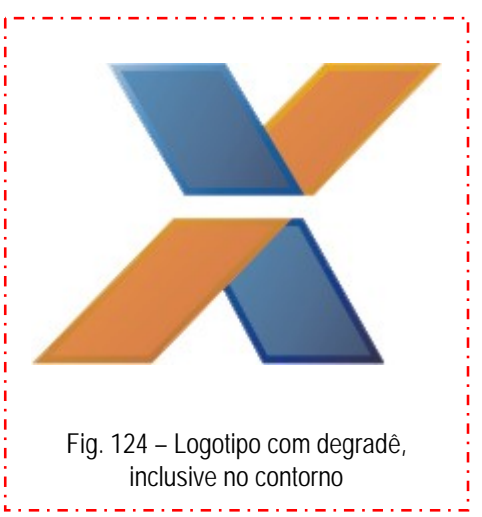

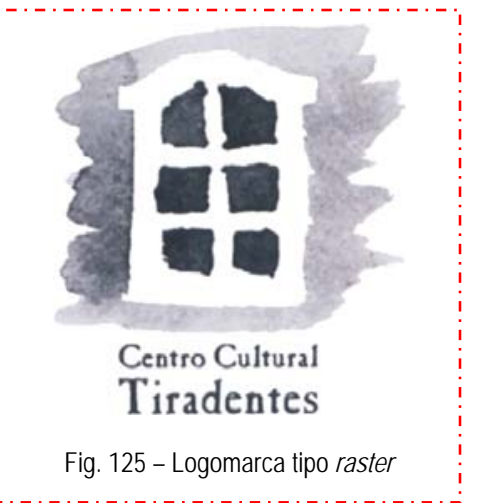

$\mathrm{Na}$ figura 124, podemos perceber que o uso de um destes elementos, o degradê, concedeu destaque à marca da Caixa: embora concebida e executada em duas dimensões, a aparência final apresenta uma simulação de tridimensionalidade, valorizando o resultado visual.

Em oposição ao desenho vetorial, há a imagem raster (em português, "trama") ou bitmap ("mapa de pedaços"), aquela que conseguimos com o uso de um scanner ("varredura"). A grande

dificuldade de se utilizar tal tipo de imagem em uma marca é quanto a ampliações e reduções: um bitmap ampliado torna-se muito pontilhado, e perde definição quando reduzido. Nestes casos, é preciso remodelar a imagem, refazendo a textura ou o padrão gráfico para cada escala de aplicação específica, sejam pequenas (cartão de visita ou envelope), médias (revistas ou cartazes) ou grandes (banners ou outdoors). 


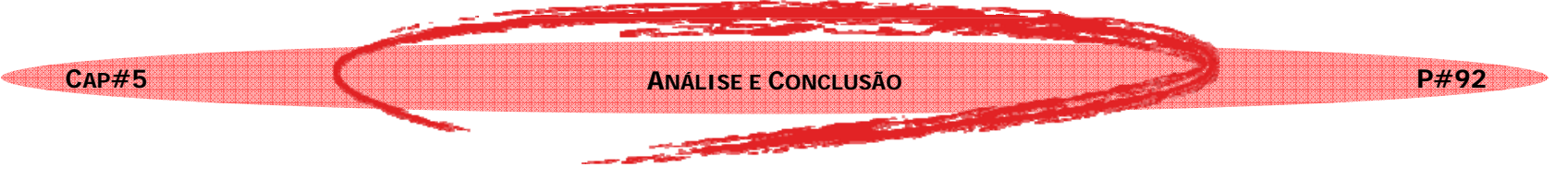

Uso de fontes de letra

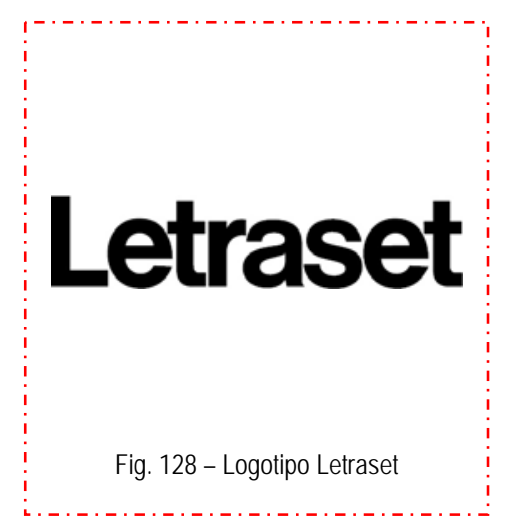

Outro aspecto importante

que o computador influenciou

decisivamente, na criação de

marcas, foi em relação ao uso de

tipos de letra. No processo de

past-up, a tipografia utilizada se

restringia a letras de desenho simples, de fácil reprodução e recorte,

ou disponíveis sob a forma de folhas de adesivo ou transferência,

que ficaram conhecidas, historicamente, pelo nome da empresa mais

famosa deste ramo, a Letraset.
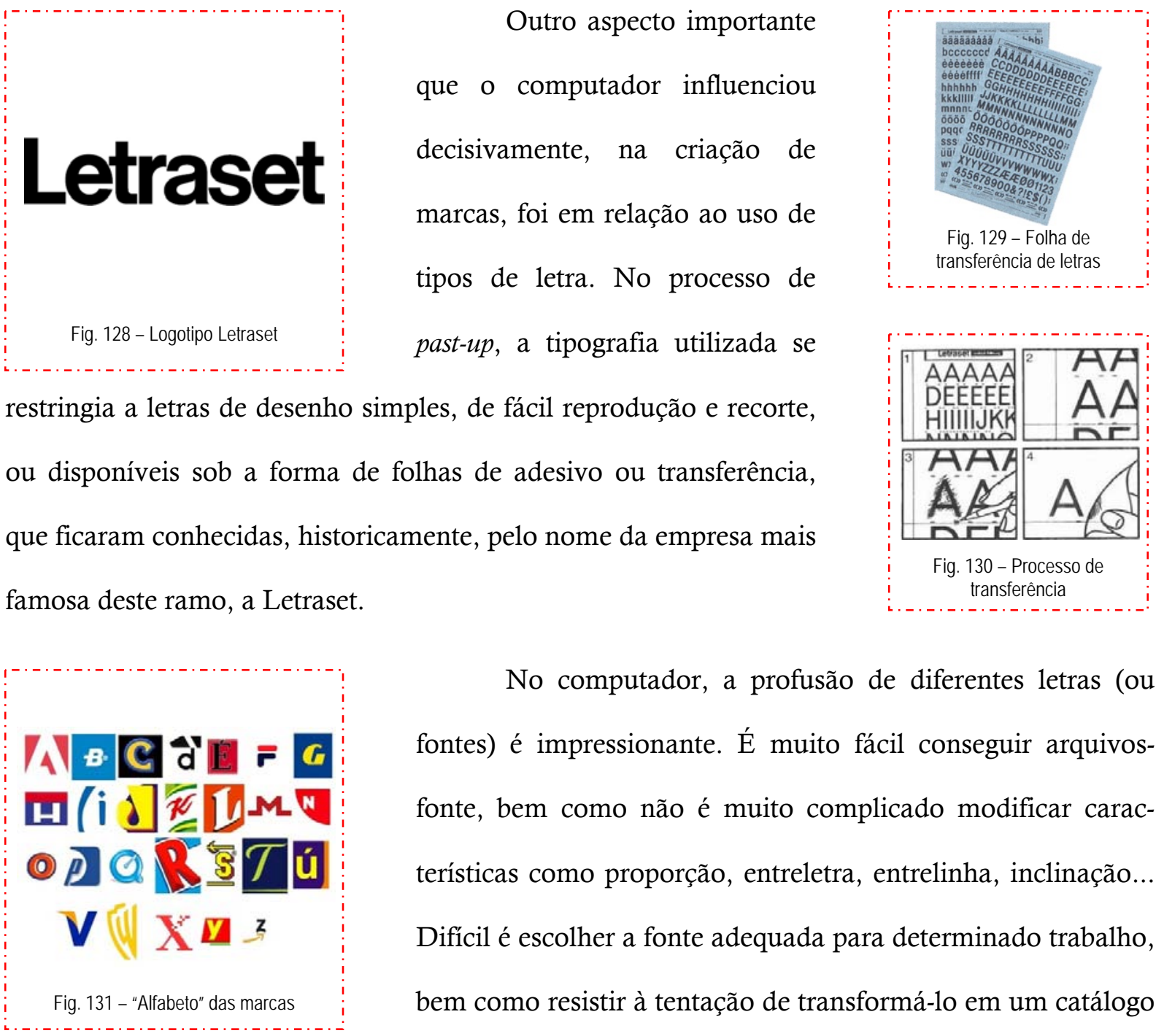

No computador, a profusão de diferentes letras (ou fontes) é impressionante. É muito fácil conseguir arquivosfonte, bem como não é muito complicado modificar características como proporção, entreletra, entrelinha, inclinação...

Difícil é escolher a fonte adequada para determinado trabalho, bem como resistir à tentação de transformá-lo em um catálogo de tipos. As opções são inúmeras: muitas vezes, para fugir do pagamento de direitos autorais, são criadas pequenas diferenças ou distorções nas proporções de fontes tradicionais, que então são distribuídas ou comercializadas com nomes diferentes.

E a confusão aumenta mais quando se leva um arquivo de um computador a outro, e este segundo não contém o arquivo-fonte utilizado: o resultado é completamente distorcido. Motivo 
pelo qual, no processo de design computadorizado, o cuidado com arquivos de apoio, como imagens, sons, vídeos e fontes, é de suma importância: é sempre necessário verificar se tais arquivos acompanham o resultado do trabalho. Para testar, muitas vezes, basta abrir o arquivo final em outro computador e revisá-lo, à caça de possíveis erros. Este deve ser um procedimento constante, especialmente para o designer gráfico.

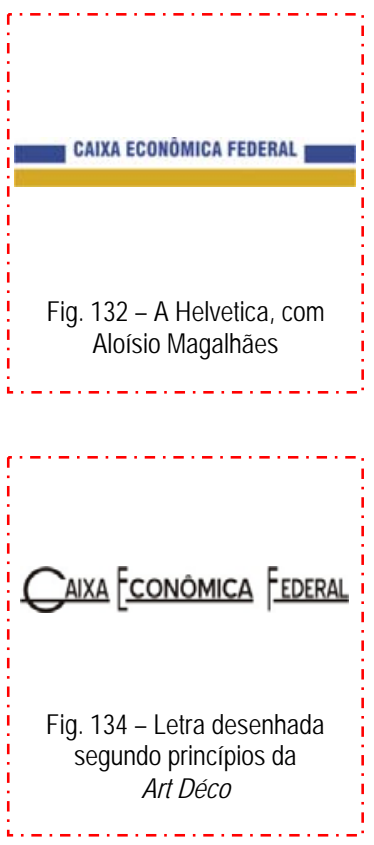

Os logotipos da Caixa apresentam casos de uso de letras comerciais (entre 1976 e 1997, utilizando a letra Helvetica Condensed) como de fontes especificamente criadas para a marca, como as desenvolvidas em 1934 (de inspiração na Art Déco) e 1970 (na qual o computador influenciou também sob a forma de linguagem) e os trabalhos mais recentes (de 1997 até hoje).
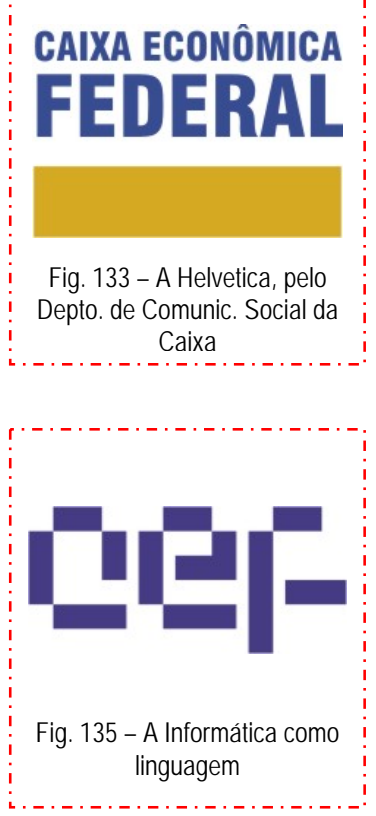

Uso de traços simples

Como apresentado no item sobre "desenho vetorial", o computador é uma excelente ferramenta para aplicação e adequação de uma marca nas mais variadas escalas. Ainda assim, há a necessidade de se atentar para os problemas advindos desta variada gama de usos da marca (de bottom a outdoor).

E esta dificuldade não se restringe à utilização de imagens raster. as linhas de contorno, bem como elementos muito delgados, apresentam sérios problemas quando ampliados ou reduzidos. Nas aplicações de dimensões muito reduzidas (canetas, cartões de visita, prendedores 
de gravata...), tanto contornos quanto outros elementos delgados podem passar despercebidos, distorcendo a correta identificação e fixação da marca. Por outro lado, quando ampliados, podem apresentar uma aparência mal acabada, com aspecto serrilhado, comum nos casos em que o preparo da imagem não foi feito corretamente.

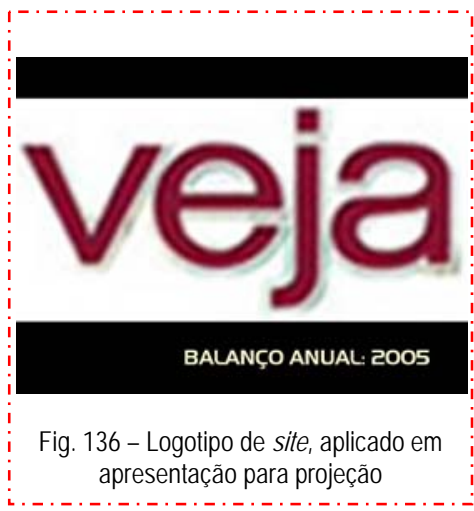

Este é o caso de quando preparamos uma imagem para uso em dimensões pequenas (como aquela que aparece site da empresa, por exemplo), exportando-o do arquivo vetorial, e depois usamos este formato para ampliar e aplicar como imagem de fundo de uma apresentação em projetor multimídia. Neste caso, para que não haja perda de qualidade, a imagem para a apresentação deveria ter sido reexportada do original, evitando a aparência de sujeira por serrilhas e pontilhados.

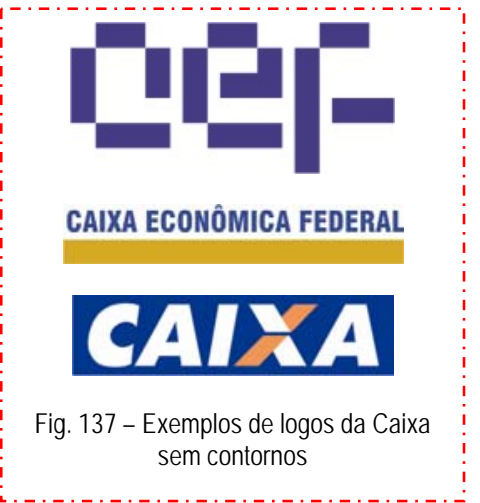

Por este motivo, entre outros, há uma tendência atual de se evitar o uso de contornos e desenhos rebuscados ou com traços muito delgados no desenvolvimento de imagens corporativas. Quando isso não é possível, sugere-se a criação de versões específicas para cada dimensão de aplicação, de forma a fixar a imagem da empresa na mente do consumidor de maneira correta e com qualidade. Em relação à empresa ora em estudo, desde o logotipo de 1970, desenvolvido pelo Serpro, que não se encontra o uso de contornos ou linhas muito delicadas: é a imagem de uma Caixa forte, segura. 
Uso de cores

Outra forte nova tendência observada na criação de marcas com o uso do computador é a relação com as cores utilizadas. Pelo processo de paste-up, a disponibilidade cromática era bastante reduzida, restritas àquelas cores oferecidas pelo sistema de aplicação ou produção utilizado: cores específicas para linotipia, outras para reprodução fotográfica, preto-e-branco para trabalhos em jornal.

Com a popularização do computador, inclusive dentro dos processos de reprodução gráfica, este panorama mudou: já se é possível conseguir cores padronizadas em quase todas as formas de aplicação, inclusive cores vivas em jornais. Entretanto, a prática demonstra que ainda é mais garantido o uso de cores simples, chamadas "chapadas" no jargão gráfico, como forma certa de visualização equiparada.

A exemplo do processo comentado acima em relação à fig. 136, o uso de cores em degradê também é viável, desde que se mantenha o procedimento de gerar imagens bitmap para cada aplicação específica, a partir de outro arquivo vetorial básico. Desta maneira, garante-se

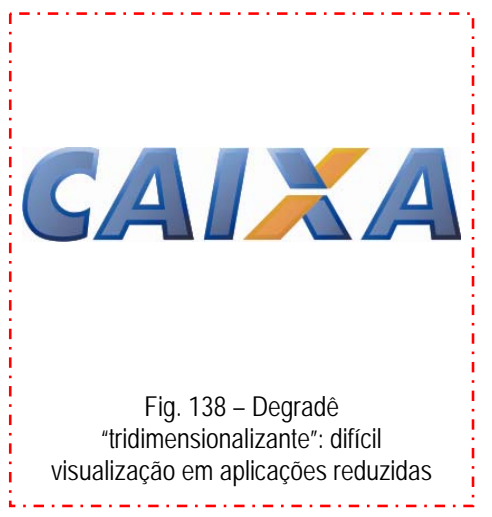
sempre a melhor imagem para cada uso, evitando, por exemplo, gradientes cromáticos em faixas, ao ampliar ou reduzir um original em escala preparada para outras dimensões de aplicação. $\mathrm{Na}$ adequação criada pelo prestigiado escritório Cauduro Martino para a Caixa, existe um logotipo com aplicação de gradiente de cores para simular a tridimensionalidade. 
E o contraste cromático também é um aspecto importante no design de identidade visual corporativa. Neste sentido, há uma tendência de se reduzir o número de cores utilizadas (entre

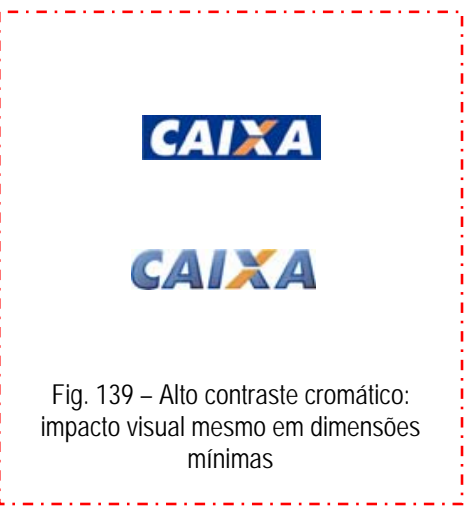
duas a quatro, na maioria dos casos), bem como evitar o uso de tom e "sobre-tom". O contraste garante um alto impacto visual mesmo nas aplicações de dimensões mais reduzidas. Por isso, ainda existe, na atual identidade visual da Caixa, concomitante ao logo em degradê, outra versão, com cores "chapadas" (laranja e branco, sobre fundo azul), com maior contraste e visual mais impactante, nas quais o "efeito 3D" seria impossível de ser reconhecido.

\section{info info info imfor info info info info info info info info info info info}

Fig. 140 - Variações monocromáticas
O uso de um reduzido número de tons também se justifica em função de uma série de aplicações monocromáticas: recibos, faxes, blocos de anotações, panfletos... Nestes casos, o gasto com impressão em quatro cores é inviável; em alguns casos, a impressão em preto pode ser trocada por uma cor diferente (azul, vermelho, verde...), motivo pelo qual identidade visual deve, quando são previsto tais usos, se sustentar em qualquer cor básica.

\section{Testes de aplicação}

Por fim, outro aspecto que o uso do computador pode ser mais vantajoso para o trabalho do design gráfico: a experimentação, os testes de aplicação. Já se comentou sobre as dificuldades práticas do processo paste-up, em especial no quesito de teste de variações: múltiplos recortes de 
elementos iguais, em cores diferentes, pequenas variações dimensionais em elementos semelhantes, diferentes formas de diagramação. Era, realmente, um trabalho ingrato...

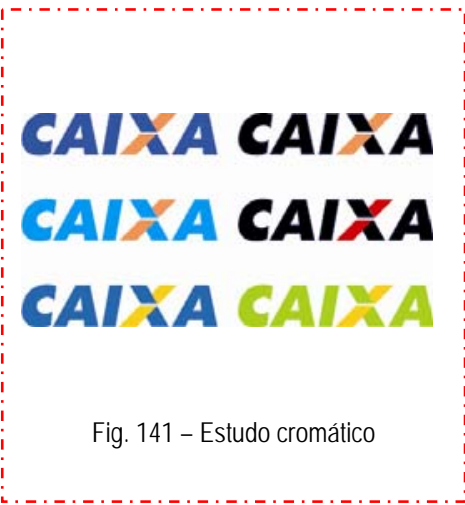

Com os programas de computação gráfica, a "tortura" é quase eliminada. Existe certa dificuldade maior inicial para se desenhar a marca; porém, a partir de tal etapa, todas as modificações se apresentam mais simples: basta um clique no mouse, um "clique-e-arraste", modificar uma variável, e temos uma nova proposta. A facilidade é tamanha, que se corre o risco de perder mais tempo nas variações que na criação. E há também o que Rogério Batagliesi chama de "Síndrome de Uainóti" ("Porque não tentar", em português):

"A facilidade de alterações de imagens, cores e afins é inesgotável e, se o interlocutor perceber alguma insegurança de nossa parte, pedirá um número infindável de testes.

'Tenta agora o roxo com o laranja'.

'Porque não o azul-royal com o terra-de-siena-pálido?'

'Eu vi um biquíni rosa-choque com verde-limão lindo! Será que não dava para você utilizar essas cores no nosso papel de carta?!' [...]" (ADG BRASIL, 2004, P. 155-156).

A criação de múltiplas diferentes opções no processo de desenvolvimento de marcas é fundamental: a quantidade facilita atingir a qualidade. Porém, é preciso atentar para o fato de estas alternativas serem realmente diferentes, e não "variações do mesmo tom".

Para que o trabalho apresente a devida qualidade, e conseqüente reconhecimento e valorização, basta criar quantas alternativas forem possíveis, selecionando apenas duas ou três melhores para apresentar ao cliente. Desta maneira, demonstra-se empenho e criatividade, sem correr o risco de uma "neo-escravatura" interminável. 

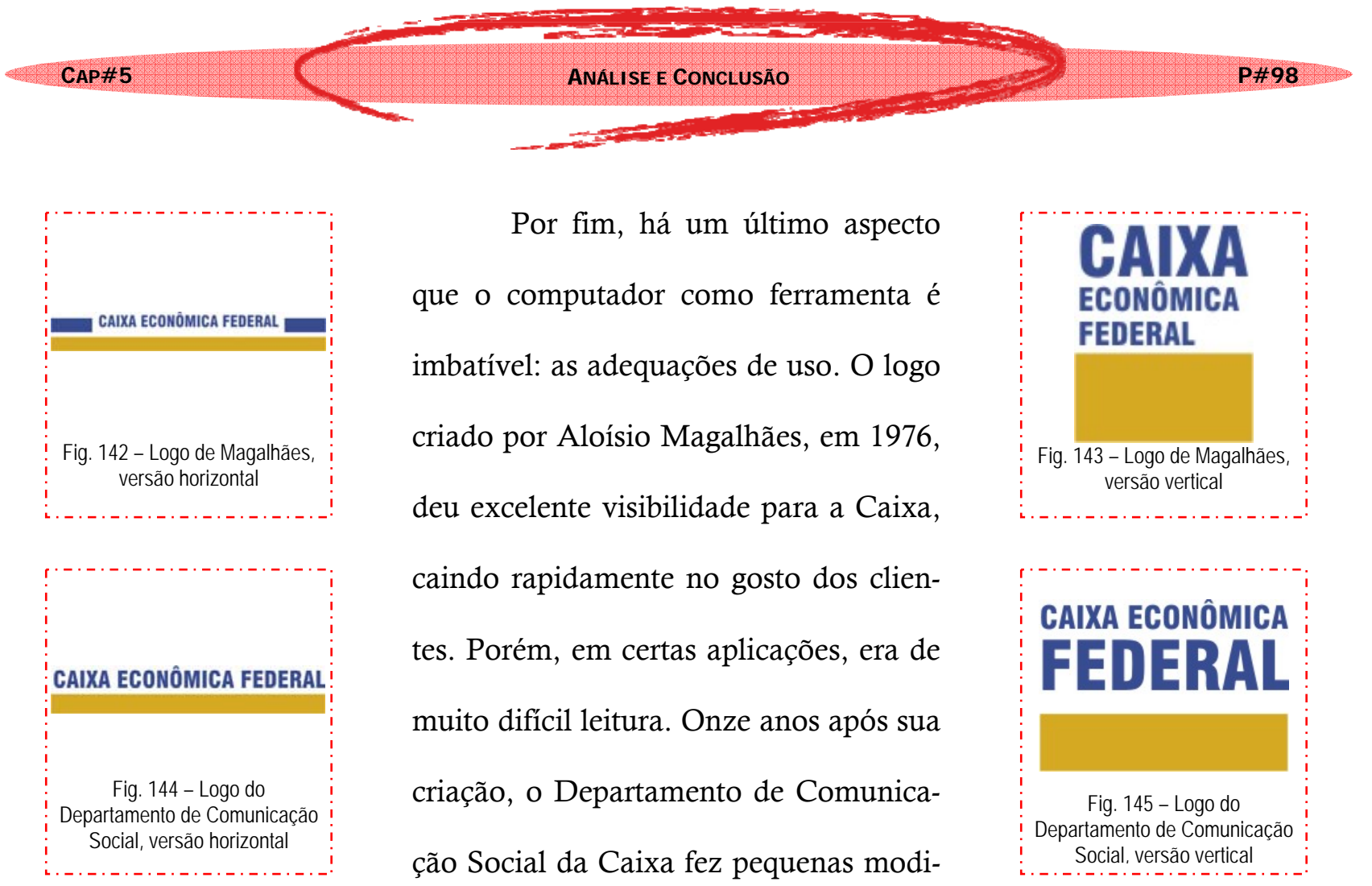

Por fim, há um último aspecto que o computador como ferramenta é imbatível: as adequações de uso. O logo criado por Aloísio Magalhães, em 1976, deu excelente visibilidade para a Caixa, caindo rapidamente no gosto dos clientes. Porém, em certas aplicações, era de muito difícil leitura. Onze anos após sua criação, o Departamento de Comunicação Social da Caixa fez pequenas modi-

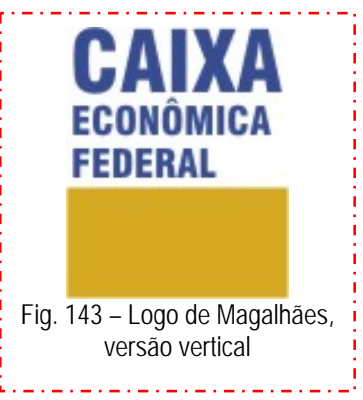

ficações no trabalho de Magalhães. O computador foi de grande importância nestas adequações: os elementos básicos não foram modificados, apenas suas relações de proporção, função para a qual os softwares gráficos são muito mais práticos que o trabalho manual tradicional.

\section{A contribuição da ferramenta computador}

Conforme foi possível avaliar por intermédio das marcas apresentadas nesta dissertação, uma empresa que investe em sua imagem, com competência e planejamento, é, normalmente, reconhecida de forma positiva por seus clientes. E este reconhecimento, através, entre outros elementos, do design de sua marca e seus produtos, valoriza a empresa.

Não é difícil perceber que o computador, se utilizado corretamente, facilita o trabalho de design, bem como torna o resultado mais flexível, adaptável, prático, com uma apresentação mais rica em detalhes que o método paste-up. Quando bem elaborada, uma marca criada pelo processo computadorizado pode apresentar elementos de qualidade superior ao tradicional. 
A correta utilização desta ferramenta depende da habilidade do profissional, que não pode relevar os conceitos básicos da profissão em detrimento da pura técnica produtiva. A atenção para evitar possíveis armadilhas no uso deste utensílio computadorizado deve ser constante: o planejamento, como o computador, é ferramenta indispensável para atingir o efeito desejado. É fundamental percorrer as etapas do planejamento visual e desenvolver o manejo dos softwares de design, bem como o necessário estudo de como e quando utilizá-la.

\section{Um mundo de marca maior}

Alguns elementos influenciados pelo uso da computação gráfica puderam ser identificados nos logotipos recentes da Caixa Econômica Federal: facilidade de aplicação e adaptação, tridimensionalidade, uso de degradês... A Caixa mostra visão de planejamento e marketing ao gerenciar com competência o que ela tem de melhor: o design e a força de sua marca.

"Qualquer idiota faz um negócio, mas é necessário genialidade, fé e perseverança para criar uma marca" (OGILVY, DAVID, APUD DEARLOVE; CRAINER, 2000, P. XXVI). Na formação de marca, "acreditar é tudo" (DEARLOVE; CRAINER, 2000, P. XXVI) e é preciso acreditar naquilo que se faz, pois "os consumidores têm tantas alternativas hoje, que [...] é melhor que você tenha uma [marca forte] se pretende competir" (D'ALESSANDRO, 2002, P. 11). E o Design tem muito a acrescentar na criação de uma marca forte.

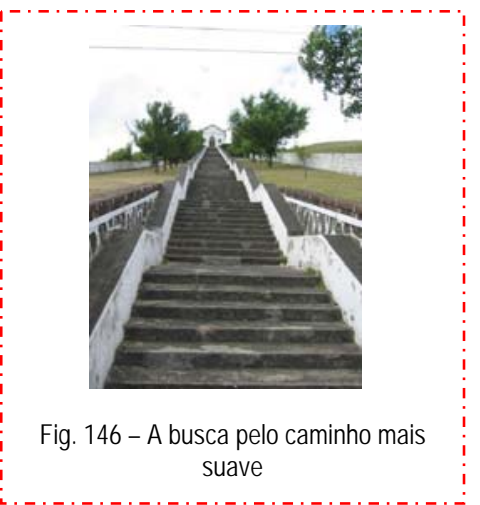

O computador traz flexibilidade e praticidade ao trabalho do designer, mas não compensa um trabalho mal elaborado. É preciso dominá-lo, para que ele não nos domine. Ou, em outras palavras: o caminho (aparentemente) mais fácil nem sempre é o mais suave... 


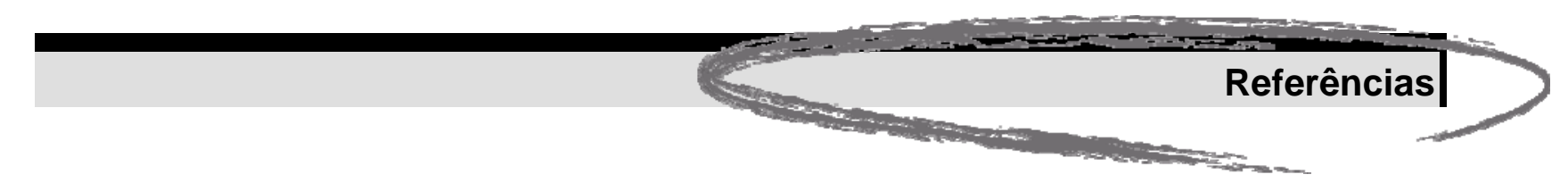




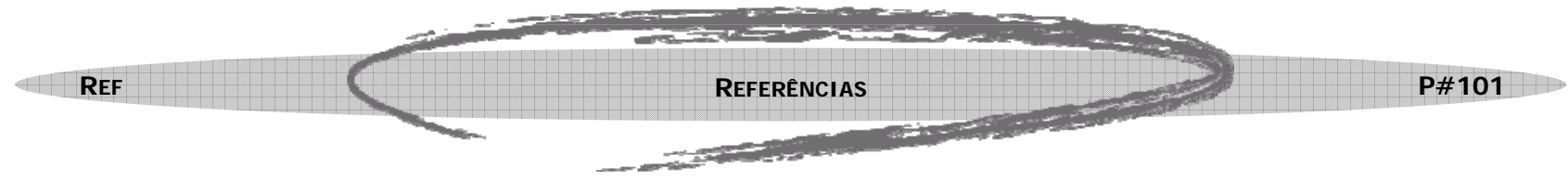

Livros

- ADG Brasil. Valor do design, o: guia ADG Brasil de prática profissional do designer gráfico. $2^{\underline{a}}$ ed. São Paulo. SENAC. 2004. 224 p. ISBN 85-7359-267-2

- ARNHEIM, Rudolf. Arte e percepção visual: uma psicologia da visão criadora. São Paulo: Pioneira/Thomson Learning, 2005. 503 p. ISBN 85-221-0148-5

- BARROS, Lílian R M. A cor no processo criativo: um estudo sobre a Bauhaus e a teoria de Goethe. São Paulo: Senac, 2006. 335 p. ISBN 85-7359-462-4

- BRINGHURST, Robert. Elementos do estilo tipográfico. São Paulo: Cosac Naify, 2005. 423 p. ISBN 85-7503-939-X

- BUENO, Eduardo. Caixa: uma história brasileira. Porto Alegre: Buenas Idéias/ Metalivros, 2002. 301 p. ISBN 85-8537-143-9 


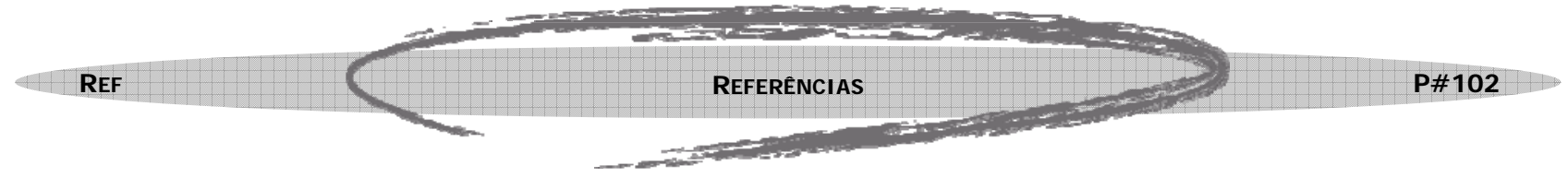

- CAPITMAN, Barbara Baer. American trademark designs: a survey with 732 marks, logos and corporate-identity symbols. Nova Iorque: Dover Publications, Inc., 1976. 160 p. ISBN 0-486-23259-X

- CARDOSO, Rafael. Introdução à história do design, uma. 2 $2^{\underline{a}}$ ed. São Paulo: Edgard Blücher, 2004. 238 p. ISBN 85-212-0340-3

- CARTER, David E. (editor) Big book of logos, the. $2^{\text {a }}$ ed. Nova Iorque: Harper Design International, 2003. 380 p. ISBN 0-06-055808-3

- _ New Big book of logos, the. $3^{\underline{a}}$ ed. Nova Iorque: Harper Design International, 2004. 384 p. ISBN 0-06-056755-4

- COBRA, Marcos H. N. Marketing básico. 4ª ed. São Paulo: Atlas, 1997. 552 p. ISBN 85-224-1540-4

- COLlaro, Antonio Celso. Projeto gráfico: teoria e prática da diagramação. $4^{\mathrm{a}}$ ed. São Paulo: Summus Editorial, 2000. 181 p. ISBN 85-323-0277-7

- COSTA E SILVA, Adriana. Branding e design: identidade no varejo. Rio de Janeiro: Rio Books, 2002. 165 p. ISBN 85-88482-04-5

- CRUZ, Carla; RIBEIRO, Uirá. Metodologia científica: teoria e prática. Rio de Janeiro: Axcel Books, 2003. 218 p. ISBN 85-7323-186-6

- D'ALESSANDRO, David F.; OWENS, Michele. Guerras de marcas: 10 regras para desenvolver uma marca vitoriosa. São Paulo: Pearson Education, 2002. 146 p. ISBN 85-346-1474-1 


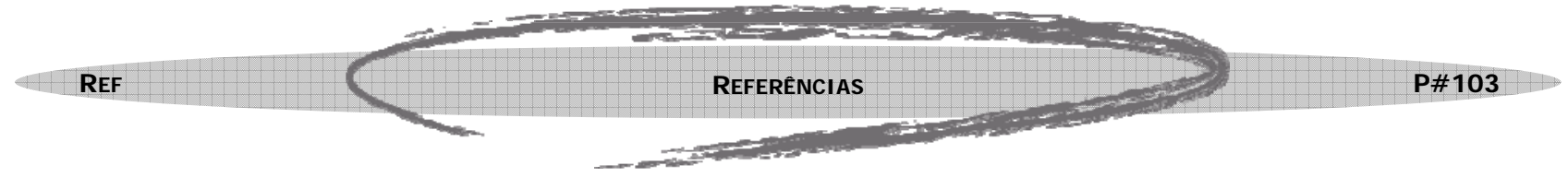

- DABNER, David. Guia de artes gráficas: design e layout. Ed. portug. Barcelona: Gustavo Gili, 2003. 128 p. ISBN 84-252-1933-7

- DANTAS, Edmundo Brandão. Marketing descomplicado. Brasília: Senac, 2005. 316 p. ISBN 85-98694-09-6

- DE MASI, Domenico (org.). Sociedade pós-industrial, a. 2 $2^{\underline{a}}$ ed. São Paulo: Senac, 1999. 443 p. ISBN 85-7359-095-5

- DEARLOVE, Des; CRAINER, Stuart. Livro definitivo das marcas, o: histórias e revelações das 50 maiores marcas do mundo. São Paulo: Makron Books, 2000. 182 p. ISBN 85-346-1134-3

- DRUCKER, Peter F. Peter Drucker na prática. Rio de Janeiro: Elsevier, 2004. 109 p. ISBN 85-352-1467-4

- ELLWOOD, Iain. Livro essencial das marcas, o. São Paulo: Clio, 2004. 368 p. ISBN 85-86324-62-1

- ESCOREL, Ana Luiza, Efeito multiplicador do design, o. 3ª ed. São Paulo: Senac, 2004. ISBN 85-7359-108-0

- FREEDMAN, Alan. Dicionário de informática. São Paulo: Makron Books, 1995. 596 p. ISBN 85-346-0473-8

- FRUTIGER, Adrian. Sinais \& símbolos: desenho, projeto e significado. $2^{\mathrm{a}}$ ed. São Paulo: Martins Fontes, 2001. 329 p. ISBN 85-336-1099-8

- GOMES FILHO, João. Ergonomia do objeto: sistema técnico de leitura ergonômica. São Paulo: Escrituras Ed., 2003. 255 p. ISBN 85-7531-071-2 


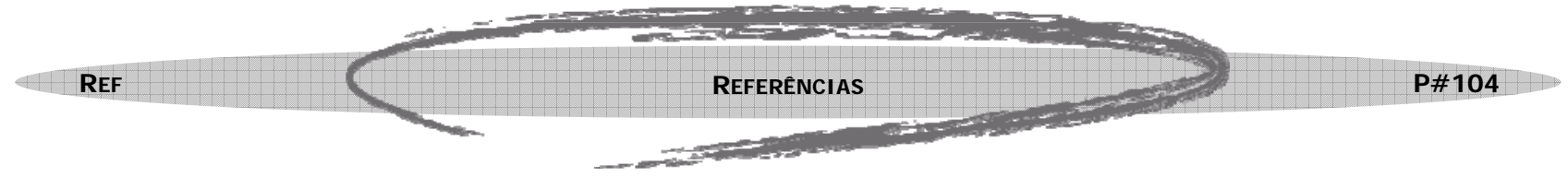

- GOMES FILHO, João. Gestalt do objeto: sistema de leitura visual da forma. São Paulo: Escrituras Ed., 2000. ISBN 85-8630-357-7

- GOOKIN, Dan; WANG, Wally; VAN BUREN, Chris. Dicionário ilustrado de Informática para leigos. Rio de janeiro: Berkley, 1994. 436 p. ISBN 85-7251-202-0

- GUITTON, Pedro. Logos do Brasil: confira os novos talentos do design nacional. Rio de Janeiro: Rio Books, 2002. 166 p. ISBN 85-88482-02-9

- _ Marca 2000. Rio de Janeiro: Rio Books, 2001.121 p. S/ ISBN.

- KLEIN, Naomi. Sem logo: a tirania das marcas em um planeta vendido. $3^{\text {a }}$ ed. Rio de Janeiro: Record, 2003. 543 p. ISBN 85-01-06262-6

- KOTLER, Philip. Administração de marketing: análise, planejamento e controle. 10 ed. Englewood Cliffs: Prentice-Hall, 2000. 764 p. ISBN 85-879-1801-X

Marketing para o século XXI: como criar, conquistar e dominar mercados. 16 ed. São Paulo: Futura, 2006. 159 p. ISBN 85-363-0440-5

- _ Marketing sem segredos, o: Philip Kotler responde as suas dúvidas. Porto Alegre: Bookman, 2005. 159 p. ISBN 85-363-0440-5

- LEITE, João de Souza. A herança do olhar: o design de Aloísio Magalhães. Rio de Janeiro: Artviva, 2003. 280 p. ISBN 85-88778-02-5

- MEIRELLES, Fernando de Souza. Informática: novas aplicações com microcomputadores. $2^{\mathrm{a}}$ ed. São Paulo: Makron Books, 1994. 615 p. ISBN 85-346-0186-0

- MUNARI, Bruno. Design e comunicação visual. São Paulo: Martins Fontes, 2001. 350 p. ISBN 85-336-0635-4 


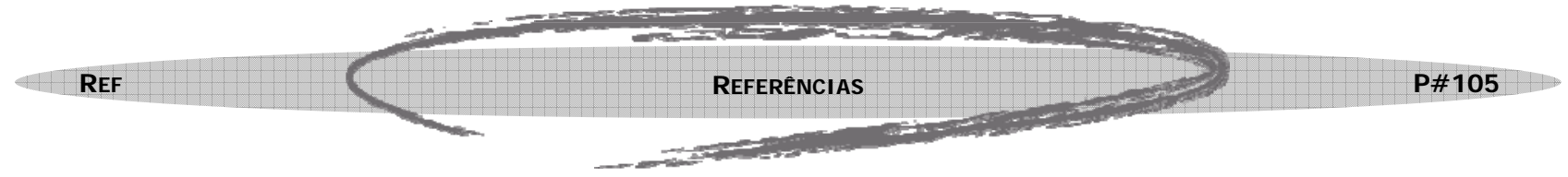

- RIBEIRO, Paulo César. História da Caixa Econômica Federal de São Paulo: 1875 a 1970. São Paulo: Editora Memória, 1997. S/ ISBN.

- RIES, Al; RIES, Laura. 11 consagradas leis de marcas na internet, as. São Paulo: Makron Books, 2001. 134 p. ISBN 85-346-1203-X

- $\quad$ Origem das marcas, a. São Paulo: M. Books, 2006. 225 p. ISBN 85-89384-79-9

- ROBERTS, Kevin. Lovemarks: o futuro além das marcas. São Paulo: M. Books, 2004. 212 p. ISBN 85-89384-59-4

- THOMAS, Gregory. How to design logos, symbols and icons: 24 internationally renowned studios reveal how they develop trademarks for print and new media. Cincinnati: How Design Books, 2003. 142 p. ISBN 1-8180-456-3

- WILLIAMS, Robin. Design para quem não é designer: noções básicas de planejamento visual. São Paulo: Callis, 1995. 144 p. ISBN 85-85642-40-8

- WOLLnER, Alexandre. Alexandre Wollner: design visual 50 anos. São Paulo: Cosac \& Naify, 2003. 336 p. ISBN 85-7503-143-0

- WONG, Wucius. Princípios de forma e desenho. São Paulo: Martins Fontes, 2001. 352 p. ISBN 85-336-0861-6 


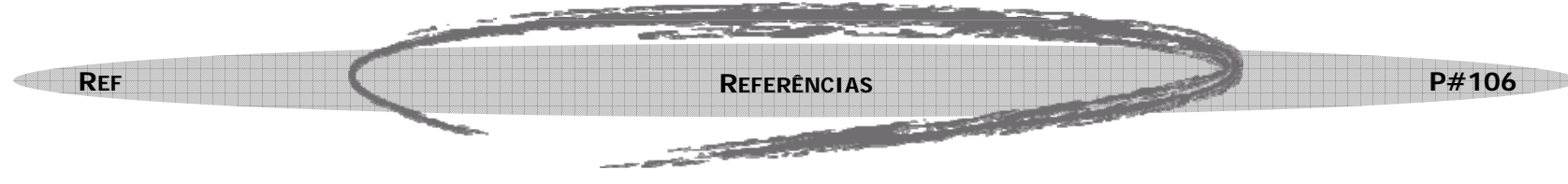

Sites

- http://pt.wikipedia.org/, acessado entre 23 de maio e 19 de julho de 2006.

- http://turnbull.mcs.st-and.ac.uk/history/, acessado entre 05 de maio e 17 de julho de 2006.

- http://universidadecorporativa.caixa [intranet], acessado entre 05 de maio e 22 de agosto de 2006.

- http://www.alaic.net/VII_congreso/gt/gt_12/GT12-4.html, acessado entre 05 de maio e 22 de agosto de 2006.

- http://www.baboo.com.br, acessado entre 05 de maio e 15 de agosto de 2006.

- http://www.caixa.gov.br, acessado entre 05 de maio e 22 de agosto de 2006.

- http://www.clubedohardware.com.br, acessado entre 05 de maio e 15 de agosto de 2006. 
- http://www.computerhope.com/history/, acessado entre 05 de maio e 07 de junho de 2006.

- http://www.cyberstreet.com/hcs/museum/chron.htm, acessado entre 05 de maio e 07 de junho de 2006.

- http://www.elsop.com/wrc/h_comput.htm, acessado entre 05 de maio e 07 de junho de 2006.

- http://www.thocp.net, acessado entre 05 de maio e 22 de agosto de 2006. 


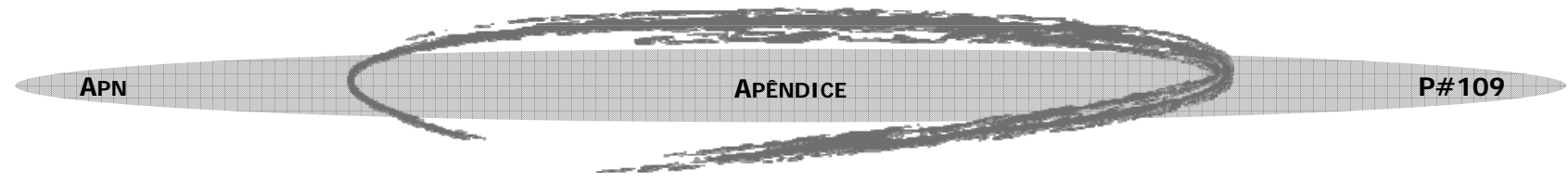

WebForum

\section{Logomarca: um erro}

O design é uma profissão nova e por isso padrões ainda não existem ou estão sendo produzidos e difundidos. Não temos padrão para quase nada, desde salário até saber o que é e o que deixa de ser a profissão. Entre esses padrões que ainda não existem, está o padrão terminológico. Em profissões antigas os termos estão bem claros e não há dúvidas sobre eles, mas no nosso caso, sempre temos que estudar um termo novo para verificar se a utilização dele é correta ou não.

Justamente por causa dessa falta de paradigmas alguns profissionais e professores utilizam e difundem termos que não são os melhores para determinados objetos. Um deles e talvez o mais polêmico é o logotipo. 


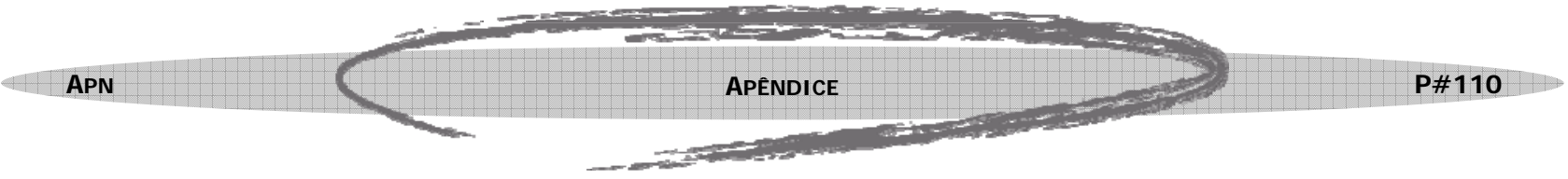

Vira e mexe temos a mesma discussão sobre esse termo, não só aqui na [dG] mas também nas agências, com os colegas, com clientes etc. Por isso eu penso que seja muito importante sermos bastante sérios a este respeito, para o bem e o crescimento dessa profissão. Então vamos analisar alguns termos e sua raiz etimológica para ver se estão corretos ou são só vícios de linguagem.

\section{Logomarca, um erro}

Muito utilizado principalmente por publicitários e marketeiros, este termo tem se difundido também entre os profissionais do design para se referir ao logotipo. Muita gente diz que está errado, outros dizem que está correto, alguns defendem o neologismo, outros afirmam que é uma aberração, mas só a pesquisa nos trará luz à questão.

\section{Logomarca como neologismo}

Neologismo é a criação de um nome novo para alguma coisa, ou um novo significado para um nome velho. Para que a "logomarca" seja um neologismo, temos que admitir que é um termo novo ou que é um termo antigo que está sendo tomado por um novo significado. Sim, admito que "logomarca" é um termo novo, mas isso não significa que seja correto empregá-lo como sinônimo de logotipo. Qualquer palavra pode ser um termo novo para algum objeto, desde que o povo a utilize para este mesmo objeto ou sentido. Mas isso não significa que esteja correto. A menos que seja uma forma conotativa da palavra, o que não é o caso da logomarca, desde que este termo é utilizado para um único tipo de objeto e significado. Então, não podemos aceitar o termo logomarca simplesmente por ser um neologismo.

\section{Sentido etimológico do termo}

O termo logomarca é formado pela união de "Logo" e "Marca". 


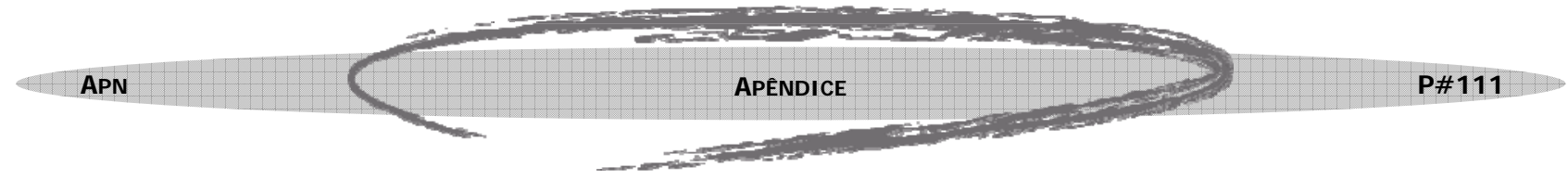

Logo, vem do grego Lógos. Significa palavra, uma narração ou pronunciamento, verbo, conceito, idéia. Mas não palavra como esta é falada ou escrita, mas o significado dela, ou seja o conceito. Reforço ainda o conceito de Logos dizendo que o termo "palavra" puro e simples no grego é Lexi.

Marca, vem do germânico Marka. Quando traduzimos do germânico, ou mesmo do português ou inglês para o latim temos o termo Signum, que traduz-se claramente para significado. E mesmo no português, e no uso moderno da palavra marca significa tudo aquilo que uma empresa representa. Sendo assim, logomarca é um termo redundante: significado do significado. Assim vemos porque não podemos utilizar este termo para falar sobre um Logotipo.

\section{Logotipo, um possível padrão}

Nunca vi absolutamente ninguém dizer que este termo está errado. Mas mesmo assim, vamos analisá-lo para ter certeza disso. Esta palavra é formada pela união dos termos "Logo" e "Tipo". "Logo", como já foi explicado, significa o conceito, idéia ou significado de uma palavra.

Tipo, do grego týpos. Em inglês traduzimos para type, que para o português significa tipo, gênero; figura; sinal, símbolo; modelo, amostra, maquete. É aí que mora o perigo: é muito mais difícil estudar qualquer assunto em português do que em inglês porque temos muitos significados para uma mesma palavra. Tipo neste caso significa um sinal ou símbolo, uma figura, um desenho. Exemplo: as vogais como "a", são tipos (símbolos gráficos) dos sons que emitimos.

Para este mesmo termo, temos ainda dois outros correspondentes em grego. Se você procurar um bom léxico inglês-grego, e procurar o termo logotype (tudo junto, não um depois o outro) você vai ver que symplegma e logotypos têm o mesmo significado já explicado acima. Aliás, poderíamos mesmo adotar como um neologismo o termo "symplegma". Imagina só o seu diretor de arte dizendo: "hum, esta symplegma não está como o cliente pediu"! 


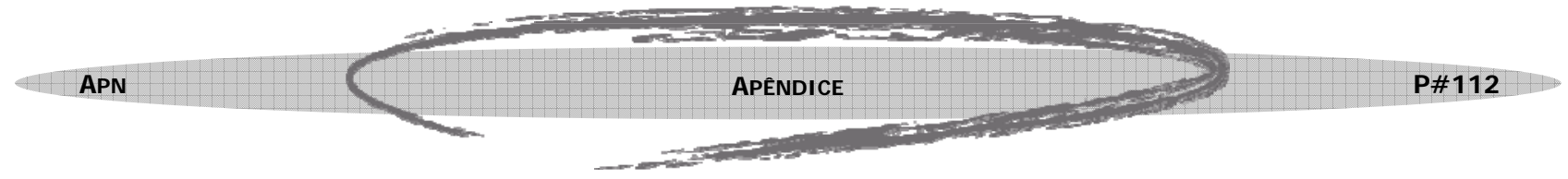

Sendo assim logotipo é: o símbolo visível de um conceito. Este termo é perfeito para o que ele significa pois é justamente o que fazemos. Temos uma empresa cliente que nos dá um conceito (logo) a trabalhar, e nós somos incumbidos a fazer um símbolo gráfico (tipo) para este conceito. Este tipo pode ser somente um desenho, sem nenhuma letra para se ler, ou somente as letras do nome da empresa mas desenhadas de forma que mostrem o conceito. Ou pode ser um desenho e o nome da empresa, juntos, mostrando o símbolo gráfico de um conceito ou logotipo.

\section{Sinal gráfico, uma alternativa coerente}

Alguns mestres de programação visual e outros profissionais estão trazendo este novo termo, este sim um bom neologismo, para o meio. Sinal, do latim Signum, significa tudo que faz lembrar ou representar alguma coisa, ou seja um significado ou conceito.

Gráfico, do grego Grafikos, significa alguma coisa colorida, pintada, desenhada, uma representação visual de algo. Seria um sinônimo de typos, porém com uma conotação de cor, colorido e menos de um símbolo gráfico, ainda que tendo sim este significado. Sendo assim, sinal gráfico significa também: o símbolo visível de um conceito.

\section{Identidade visual, muito bom se usado corretamente}

Este é outro termo utilizado por alguns designers, tem um significado bem claro e objetivo. Identidade é o conjunto de peculiaridades de uma pessoa, coisa ou empresa. Visual, o que se pode ver. O problema desse termo é que ele não enfoca o conceito, a idéia, a palavra. Mas significa, no ramo do design, as peculiaridades gráficas de uma empresa. Essas individualidades visuais são muito mais abrangentes que somente o logotipo, pois abrangem o site, os cartões de visita, os carros, uniformes, enfim, todo aparato visual de uma empresa.

\section{O termo correto, sempre!}




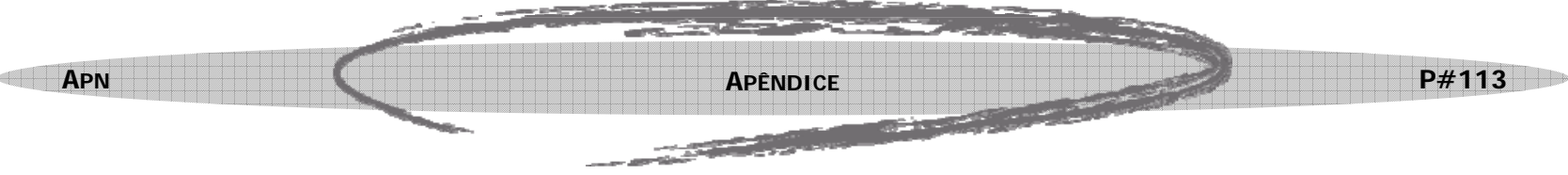

Como já disse, somos já membros de um corpo de profissionais que sofrem bastante com a confusão que a sociedade ainda faz conosco, por ser o design uma profissão nova. O mínimo que podemos fazer é ser coerentes ao falar de um dos mais importantes ramos de atividade do design que é a logotipia.
Abraços,
Gilberto Alves Jr.
matéria retirada do site: design gráfico 